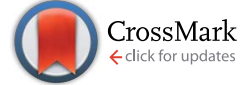

Cite this: Nat. Prod. Rep., 2016, 33, 1044

Received 15th February 2016

DOI: 10.1039/c6np00021e

www.rsc.org/npr

\title{
Recent advances in research on lignans and neolignans
}

\author{
Rémy Bertrand Teponno, $\uparrow^{\mathrm{ab}}$ Souvik Kusari $\dagger^{\mathrm{a}}$ and Michael Spiteller ${ }^{\star a}$
}

Covering: 2009 to 2015

Lignans and neolignans are a large group of natural products derived from the oxidative coupling of two C6-C3 units. Owing to their biological activities ranging from antioxidant, antitumor, anti-inflammatory to antiviral properties, they have been used for a long time both in ethnic as well as in conventional medicine. This review describes 564 of the latest examples of naturally occurring lignans and neolignans, and their glycosides in some cases, which have been isolated between 2009 and 2015. It comprises the data reported in more than 200 peer-reviewed articles and covers their source, isolation, structure elucidation and bioactivities (where available), and highlights the biosynthesis and total synthesis of some important ones.

1 Introduction

1.1 Definition

1.2 Biosynthesis and distribution of lignans and neolignans

1.3 Hyphenated techniques used for the isolation, identification and quantification of lignans and neolignans

2 Lignans

2.1 Dibenzocyclooctadiene derivatives

2.2 Arylnaphthalene and aryltetralin derivatives

2.3 Dibenzylbutane, dibenzylbutyrolactol and dibenzylbutyrolactone derivatives

2.4 Furofuran derivatives

2.5 Furan derivatives

3 Neolignans

3.1 Benzofurans

3.2 Alkyl aryl ethers

3.3 Benzodioxanes

3.4 Biphenyl neolignans

3.5 Other neolignans

4 Miscellaneous

5 Outlook

6 Acknowledgements

7 Notes and references

\section{Introduction}

The last decade has witnessed a renewed interest in biologically active compounds isolated from a plethora of natural resources, in addition to impressive progress in allied methodologies such as combinatorial chemistry and high-throughput screening. Given the advantages of formulations containing compounds obtained from natural resources over compounds obtained by total synthesis, including relatively low toxicity, complete biodegradability, and in some cases, lower production costs, an emerging global impetus towards natural product research is presently observed. ${ }^{1}$ Lignans and neolignans represent an enormous class of pharmacologically active compounds. However, there is currently insufficient updated information on this important class of natural products, with a comprehensive review on their chemistry, bioactivity and synthesis published long back in 2009. ${ }^{2}$ Remarkable advances have been made in the isolation and identification of lignans and neolignans in the recent years, which has already led to about 500 new congeners and most of which possess beneficial pharmacological effects. Among these, dibenzocyclooctadiene lignans isolated principally from plants of the Schisandraceae family (Kadsura and Schisandra genera) have been the most abundant class with about 131 new compounds. However, there is currently a dearth of a unifying review that provides a comprehensive account of lignans and neolignans reported in the recent years. Therefore, the objective of the present review is to compile the source, identification, bioactivities, biosynthesis and total synthesis of bioactive lignans and neolignans isolated and characterized between 2009 and 2015, a period that marks enormous progress in the discovery of this interesting class of compounds. 


\subsection{Definition}

Lignans and neolignans are a large group of naturally occurring phenols which are widely spread within the plant kingdom and are derived from the shikimic acid biosynthetic pathway. These compounds show dimeric structures formed by a $\beta, \beta^{\prime}$-linkage between two phenyl propane units with a different degree of oxidation in the side-chain and a different substitution pattern in the aromatic moieties. ${ }^{3}$ Similar to the ecological functions of several other secondary metabolites, lignans represent a means of protection against herbivores and microorganisms for the plants that synthesize them. For nomenclature purposes, the C6C3 unit is treated as propylbenzene and numbered from 1 to 6 in the ring, starting from the propyl group, and with the propyl group numbered from 7 to 9 , starting from the benzene ring. With the second C6-C3 unit, the numbers are primed. When the two C6-C3 units are linked by a bond between positions 8 and $8^{\prime}$, the compound is named as a "lignan". In the absence of the C-8

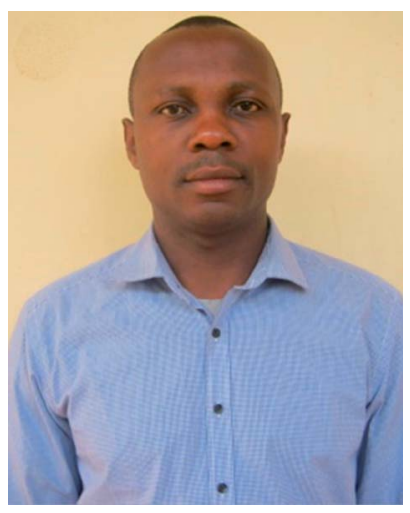

Rémy Bertrand Teponno is Senior Lecturer/Researcher at the Department of Chemistry, University of Dschang (Cameroon) where he received his Ph.D. degree in Organic Chemistry/ Natural Products Chemistry in 2009. He undertook postdoctoral trainings at the Institute of Organic Chemistry, Johannes Gutenberg University of Mainz (Germany) in 2012 and at the Graduate School of Pharmaceutical Sciences, Kyushu University (Japan) in 2014. He is now a Georg Forster postdoctoral fellow at INFU, TU Dortmund, Germany. His research focuses on bioactive secondary metabolites from medicinal plants and endophytic fungi.

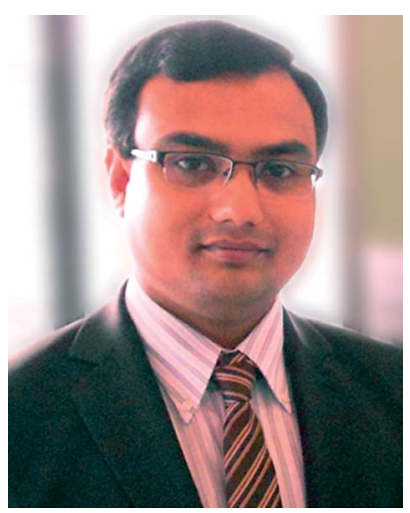

Souvik Kusari is currently head of the working group "Chemical Microbiology" at INFU, TU Dortmund, Germany, as well as a visiting researcher at the Department of Plant Sciences, University of Oxford, United Kingdom. He received bachelor and master degrees in Biotechnology from Bangalore University, India. He then earned a doctorate in Natural Sciences from INFU, TU Dortmund in 2010. After working as a scientist at INFU for over two years, he visited the Department of Plant Sciences, University of Oxford for a year in 2013. He was also a visiting lecturer at the University of Yaoundé 1, Cameroon from 2012 to 2014 within the scope of the BMBF/DAAD "Welcome to Africa" initiative. His research interests include characterization of fungal and bacterial endophytes to evaluate their diversity, chemical ecology and biosynthetic pathways.<smiles>Cc1cc2ccccc2c(Br)c1C</smiles><smiles>CC1Cc2ccccc2C(Br)C1C</smiles>

AryInaphthalene
Aryltetralin

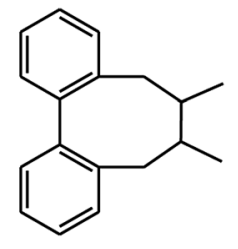

Dibenzocyclooctadiene<smiles>CC(CBr)C(C)CBr</smiles><smiles>OC1OCC(C[Te])C1C[Te]</smiles>

Dibenzylbutyrolactol

Dibenzylbutyrolactone

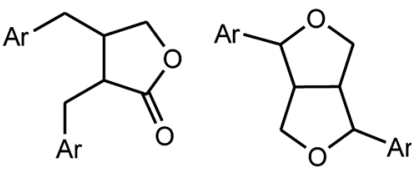

Furofuran

Dibenzylbutane

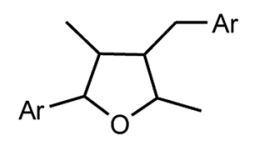

2-aryl-4-benzyltetrahydrofuran

Furan

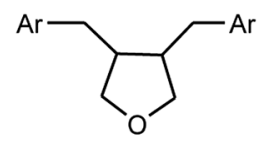

3,4-dibenzyltetrahydrofuran

Fig. 1 Subtypes of classical lignans (Ar $=$ aryl).

to $\mathrm{C}-8^{\prime}$ bond, the dimer formed from the two C6-C3 units is a "neolignan"., Compounds in which an ether oxygen atom provides the linkage between the two C6-C3 units, are also classified under neolignans and are called oxyneolignans. Norlignans are defined as a group of related natural compounds, usually found to co-occur with lignans or neolignans, which have a C16 to C17 core structure. From the biosynthetic point of view, these compounds are plausibly derived from two arylpropane units by the loss of one or two carbons, probably through decarboxylations.

As depicted in Fig. 1, lignans are classified into eight groups on the basis of their structural patterns, including their carbon skeletons, the way in which oxygen is incorporated into the skeletons, and the cyclization pattern. These are arylnaphthalene, aryltetralin, dibenzocyclooctadiene, dibenzylbutane, dibenzylbutyrolactol, dibenzylbutyrolactone, furan, and furofuran. ${ }^{5,6}$ Neolignans

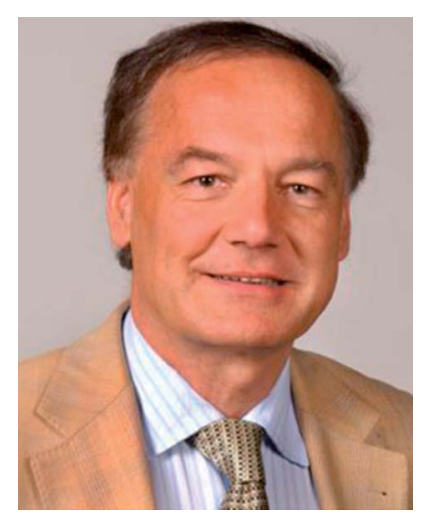

Michael Spiteller received his Diploma in Chemistry (1976) from the Georg-August-Universität in Göttingen, Germany where he earned a doctorate in Chemistry in 1979. After Habilitation in Soil Science, he joined the Institute for Metabolism and Environmental Fate, Bayer Corp., Germany for 8 years as a Group Leader. He then joined the University of Kassel as a full Professor and is now Professor and Head of INFU, TU Dortmund, Germany. He is involved in various projects dealing with natural product drug discovery from plants and endophytes, structural identification of unknown xenobiotics and their metabolites, metabolism of pesticides in the environment, and veterinary drugs. 
<smiles>CCCc1ccc2c(c1)C(C)C([Al])O2</smiles>

NL1<smiles>CCCC1CCCC(C(C)C[AlH2])C1</smiles>

NL6<smiles>CC1C(Br)CCCC12CCCCC2</smiles>

NL11<smiles>CCCc1ccc2c(c1)OC([Al])C(C)O2</smiles>
NL2<smiles>CCCc1ccc(OC(C)CBr)cc1</smiles>

NL3<smiles>CCCc1cccc(-c2cccc(C)c2)c1</smiles>

NL4<smiles>CCCC12CCC(C1)C(Br)C2C</smiles>

NL9

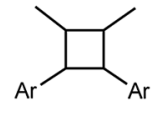

NL5<smiles>CCCC1(C(C)C[Al])CCCCC1</smiles>

NL7

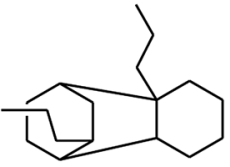

NL12<smiles>CCCOc1ccc(C(C)C[Al])cc1</smiles>

NL8

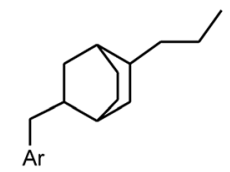

NL13<smiles>[Al]CCCCCBr</smiles>

NL14

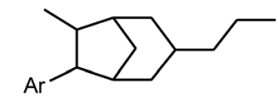

NL10

Fig. 2 Subtypes of neolignans (NL).

consist of fifteen subtypes designated as NL1 to NL15 (see Fig. 2) and no special names have been assigned to them. ${ }^{2,7}$

\subsection{Biosynthesis and distribution of lignans and neolignans}

Both lignans and neolignans originate from cinnamic acid derivatives which are related biochemically to the metabolism of phenylalanine. Chorismic acid is transformed into prephenic acid via a Claisen rearrangement, which transfers the phosphoenolpyruvate derived side-chain so that it becomes directly bonded to the carbocycle, and thus builds up the basic carbon skeleton of phenylalanine. Decarboxylative aromatization of prephenic acid yields phenylpyruvic acid, and pyridoxal phosphate-dependent transamination leads to L-phenylalanine. ${ }^{\mathbf{8}, 9}$ The biosynthesis of coniferyl alcohols is initiated with deamination of phenylalanine by phenylalanine ammonialyase to form cinnamic acid, which is then hydroxylated by a P450 enzyme, cinnamate 4-hydroxylase, to form $p$-coumaric acid. Coniferyl alcohol is derived from the reduction of coumaric acid via coenzyme A ester to an aldehyde, which is further reduced in the presence of a NADPH molecule. Formation of the coenzyme<smiles>C=C(O[C@H]1C=C(C(=O)O)C=C[C@H]1O)C(=O)O</smiles><smiles>N[C@@H](C[C@]1(C(=O)O)C=C[C@@H](O)C=C1)C(=O)O</smiles>

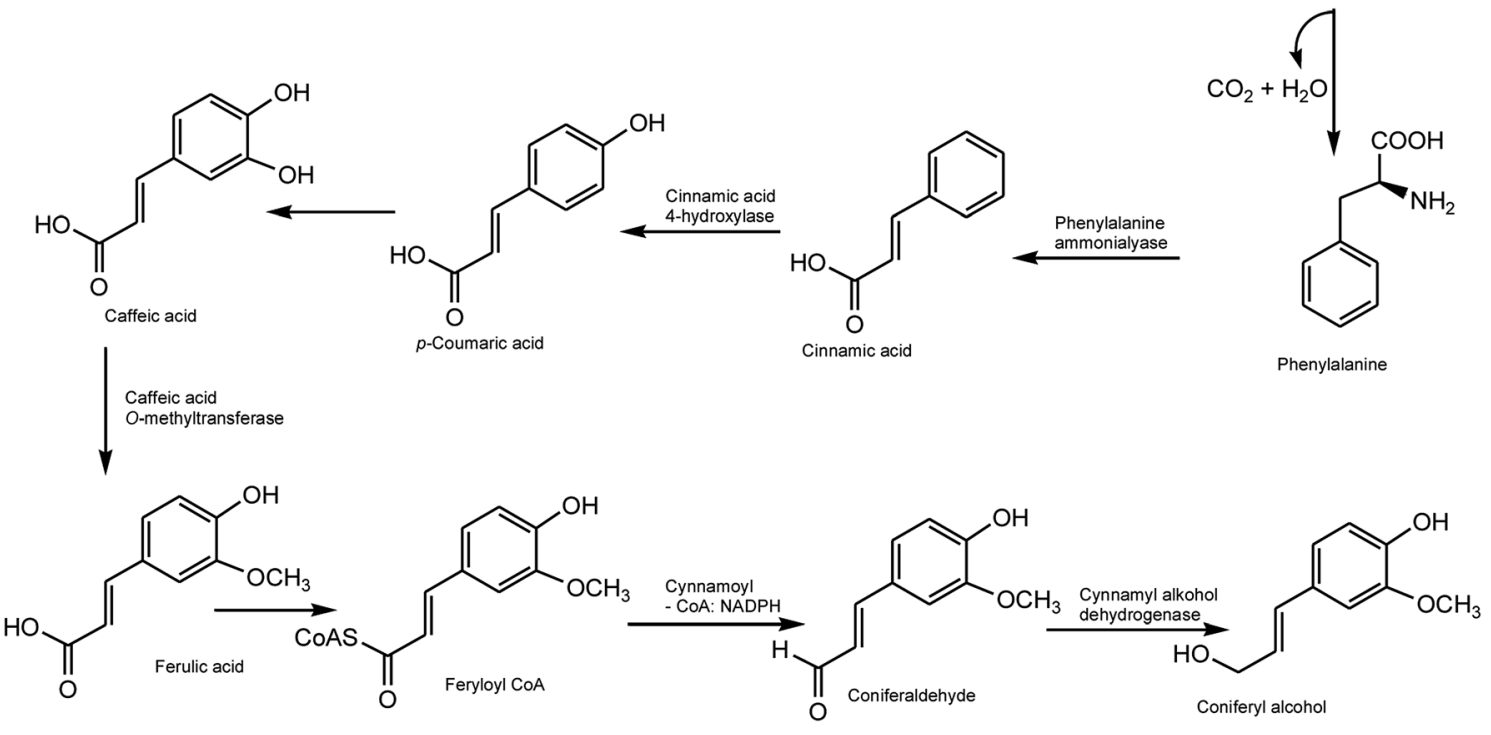

Scheme 1 Biogenesis of coniferyl alcohol. 
A ester facilitates the first reduction step by introducing a better leaving group $\left(\mathrm{CoAS}^{-}\right)$for the $\mathrm{NADPH}$-dependent reaction (Scheme 1). ${ }^{\mathbf{8}, 9}$
The biosynthesis of lignans with $9\left(9^{\prime}\right)$-oxygen is very well studied that is clearly revealed by some important results obtained in the last couple of years. This type of lignan is formed by

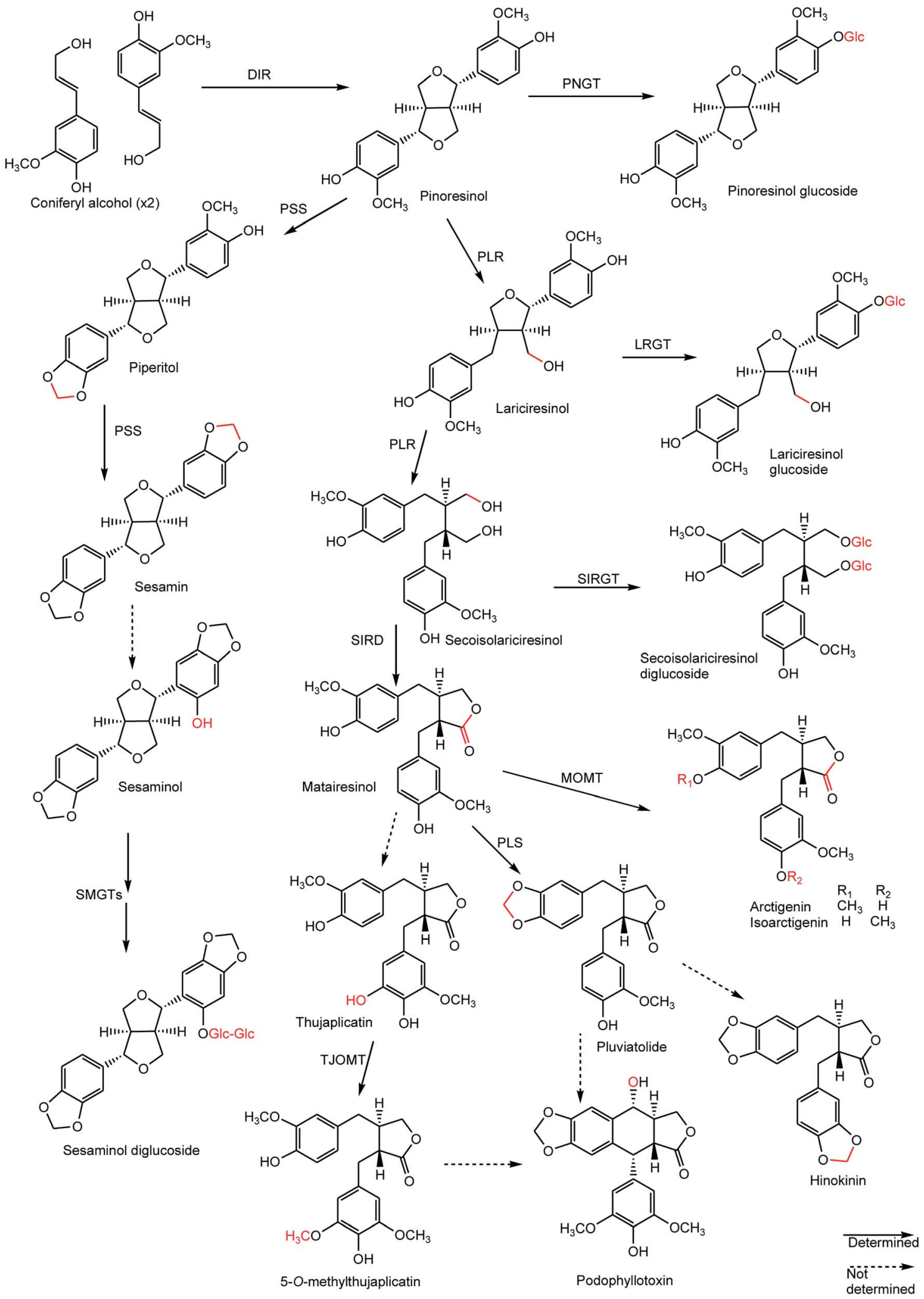

Scheme 2 Biosynthetic pathways of major lignans: chemical conversions at each step are indicated in red, solid and broken lines represent identified and unidentified enzyme-catalyzed reactions, respectively. 
enantioselective dimerization of two coniferyl alcohol units with the aid of a dirigent protein (DIR) to give rise to pinoresinol (furofuran). Pinoresinol is then reduced to secoisolariciresinol (dibenzybutane) by pinoresinol/lariciresinol reductase (PLR), via lariciresinol (furan), which is in turn oxidized to afford matairesinol (dibenzylbutyrolactone) by secoisolariciresinol dehydrogenase (SIRD) (Scheme 2). The conversion from coniferyl alcohol to matairesinol has been demonstrated in various plant species, which strongly suggests that this is the general biosynthetic pathway of lignans. ${ }^{5,6,9}$ Pinoresinol also undergoes glucosylation by a putative pinoresinol glucosyltranferase (PNGT). Such glycosylation is highly likely not only to suppress the chemical reactivity of a phenolic hydroxyl group of pinoresinol but also to potentiate high water solubility of pinoresinol aglycone, resulting in large and stable amounts of pinoresinol. ${ }^{10}$ Similar to pinoresinol, lariciresinol and secoisolariciresinol can be glycosylated by the action of lariciresinol glycosyltransferase (LRGT) and secoisolariciresinol glycosyltransferase (SIRGT), respectively (Scheme 2). In various plants such as Forsythia koreana, Carthamus tinctorius, and Anthriscus sylvestris, matairesinol is metabolized to arctigenin/isoarctigenin by matairesinol O-methyltransferase (MOMT) via methylation of a phenolic hydroxyl group. ${ }^{11,12}$ Additionally, $70-90 \%$ of matairesinol is glucosylated throughout the year in the Forsythia leaves, although no matairesinol-glucosylating enzymes have been identified. ${ }^{13}$ In Linum, Anthriscus, and Podophyllum plants, matairesinol is also converted into hinokinin, yatein or podophyllotoxin via multiple biosynthetic pathways, even though all relevant enzymes have not yet been identified. ${ }^{6}$ The isolation and characterization of a thujaplicatin-specific plant $O$-methyltransferase (TJOMT) from A. sylvestris that exclusively catalyzed regioselective methylation of thujaplicatin to produce 5-O-methylthujaplicatin, a biosynthetic precursor of the lignan podophyllotoxin, was recently reported by Ragamustari et al ${ }^{14}$ Furthermore, next generation sequencing (NSG) coupled to bioinformatics and metabolome analyses of Podophyllum tissues led to the discovery of two putative unknown genes in the podophyllotoxin biosynthetic pathway. ${ }^{15}$ The cytochrome P450s CYP719A23 from P. hexandrum and CYP719A24 from P. peltatum were capable of specifically converting (-)-matairesinol to (-)-pluviatolide by catalyzing methylenedioxy bridge formation and did not act on other possible substrates that were tested. On one hand, the enzymes described in this study were highly similar to methylenedioxy bridge-forming enzymes from alkaloid biosynthesis. On the other hand, candidates more similar to lignan biosynthetic enzymes were catalytically inactive with the substrates employed. Pinoresinol is metabolized into piperitol, followed by further conversion into (+)-sesamin by piperitol/sesamin synthase (PSS), a cytochrome P450 family enzyme, CYP81Q1, which is responsible for the formation of two methylenedioxy bridges (Scheme 2). Although sesamin is anticipated to be further metabolized into sesaminol, the underlying molecular mechanisms have not yet been elucidated. Sesaminol is glucosylated at its 2-hydroxyl position by sesaminol 2-O-glucosyltransferase (SMGT) in Sesamum radiatum, Sesamum indicium, and Sesamum alatum. ${ }^{6}$

Schisandraceae plants are rich in lignans, especially dibenzocyclooctadiene lignans, ${ }^{16-18}$ which show varied beneficial pharmacological effects including anti-HIV, antitumor- promoting, calcium antagonistic, and anti-lipid peroxidative actions. ${ }^{18,19}$ Furofuran type lignans are widely distributed in edible plants [flaxseed, sesame (Pedaliaceae), seeds, cereal products (Poaceae or Gramineae), and Brassica vegetables (Brassicaceae)]. Most of these dietary lignans are metabolized by the gut microflora to enterolactone and enterodiol, also known as enterolignans, and are traditionally classified as<smiles>COc1cc2c(c(OC)c1OC)-c1c(cc3c(c1OC)OCO3)[C@@H](OC(C)=O)[C@@H](C)[C@@H](C)C2</smiles><smiles>[R]O[C@@H]1OCOc2c3cc1c(c2OC)-c1c(cc(OC)c(OC)c1OC)[C@H](O)[C@@H](C)[C@@H](C)[C@@H]3O</smiles>

3: $\mathrm{R}=\mathrm{H}$

4: $R=A c$

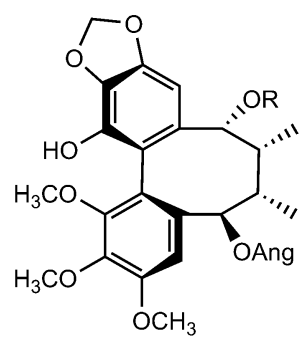

22: $\quad R=A C$

23: $R=$ Prop

24: $\quad R=$ Isoval
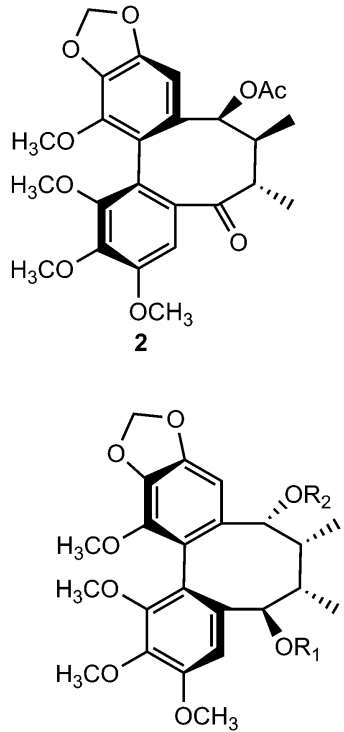

5: $R_{1}=A c, R_{2}=H$ 6: $R_{1}=A c, R_{2}=A c$ 7: $R_{1}=A c, R_{2}=$ Prop 8: $R_{1}=A c, R_{2}=$ Isobut 9: $R_{1}=A c, R_{2}=$ But 10: $R_{1}=A c, R_{2}=$ Isoval 11: $R_{1}=A c, R_{2}=B z$ 12: $R_{1}=$ Tig, $R_{2}=A C$ 13: $R_{1}=$ Ang, $R_{2}=$ Isobut 14: $R_{1}=$ Ang, $R_{2}=$ But 15: $R_{1}=B z, R_{2}=H$

16: $R_{1}=B z, R_{2}=A C$

17: $R_{1}=B z, R_{2}=$ Prop

18: $R_{1}=B z, R_{2}=B u t$

19: $R_{1}=B z, R_{2}=$ Isobut

20: $R_{1}=B z, R_{2}=$ Isoval

21: $R_{1}=$ Ang, $R_{2}=$ Isoval
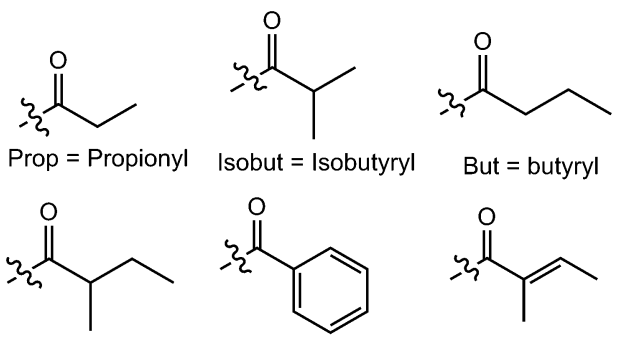<smiles>CC(=O)c1ccccc1</smiles><smiles>CC=C(C)C(C)=O</smiles>

Isoval = Isovalery|
Tig = tigloyl<smiles>C/C=C(/C)C(=O)O</smiles>

Ang = angeloyl 
phytoestrogens ${ }^{\mathbf{2 0}}$ which have demonstrated protective efficacies against prostate and breast cancer. ${ }^{21,22}$

\subsection{Hyphenated techniques used for the isolation, identification and quantification of lignans and neolignans}

Phenolic compounds such as lignans and neolignans are commonly extracted using organic and/or inorganic solvents. Several parameters may influence the extraction efficacy and yield, including extraction time, temperature, solvent-to-sample ratio, the number of repeat extractions of a sample, in conjunction with the type of solvent employed. Furthermore, the optimum recovery is mostly different when comparing one sample to the other and relies on the type of plant tissue and its active constituents. The choice of extraction solvents such as water, acetone, ethyl acetate, alcohols (such as methanol, ethanol and propanol) and their mixtures have been shown to influence the yield. ${ }^{23}$ The remarkable improvement in hyphenated analytical techniques in the recent years has significantly broadened the scope and application of these techniques in the analysis of natural products. High-performance liquid chromatography (HPLC) with photodiode array detector (PDA) and tandem mass spectrometry $\left(\mathrm{MS}^{n}\right)$ has facilitated qualitative and quantitative evaluation of lignans. ${ }^{24,25}$ For example, an accurate, sensitive and reliable method was developed in 2012 using HPLC coupled to PDA and a mass spectrometer for quantitative analysis of twelve lignans in the fruit of the Chinese medicinal plant Schisandra sphenanthera. ${ }^{26}$ The chemodiversity of Linum plants (Linaceae) was explored by Schmidt et al. ${ }^{27}$ who identified 64 different lignans of the aryltetralin-, arylnaphthalene-, aryldihydronaphthalene-, dibenzylbutyrolactone-, and furofurantypes from 41 Linum species by means of HPLC-ESI-MS/MS.

Although HPLC-MS ${ }^{n}$ allows identification of compounds by taking into account retention times and mass spectral data, gas chromatography (GC) coupled with electron capture detection (ECD) has been shown to be another highly sensitive technique that can detect specific substances in complex matrices up to the picogram or even femtogram level. A new method for lignan analysis in wheat bran using GC with ECD was presented by Cukelj et al. ${ }^{28}$ The method was relatively simple, requiring methanolysis and enzymatic hydrolysis, followed by solid-phase extraction as the sole technique for sample concentration and purification. Furthermore, lignans were detected and quantified for the first time in pomegranate (Punica granatum L.) and in commercial pomegranate juices by means of GC-MS. ${ }^{29}$ Furthermore, a rapid and sensitive micellar electrokinetic capillary chromatography method has recently been developed for the simultaneous quantitative analysis of eight lignans in the seed, pulp, stem, rattan and leaf tissues of Schisandra sphenanthera. ${ }^{30}$

\section{Lignans}

\subsection{Dibenzocyclooctadiene derivatives}

About 131 dibenzocyclooctadiene lignans, isolated mainly from the plant genera Kadsura and Schisandra belonging to the family Schisandraceae, were published as natural products between
2009 and 2015. Strikingly, this class of lignans has seen remarkable growth in the number of new examples reported recently, with more than 130 in the period 2009 to 2015 compared to only 32 in the previous four years. The structures and absolute configurations of fourteen new dibenzocyclooctadiene lignans, ananolignans A-N (1-14) isolated from the seeds of Kadsura ananosma, were established using a combination of spectroscopic methods and CD techniques. Ananolignans F and ananolignan L showed the most promising in vitro cell survival data against oxidative stress-induced neurotoxicity. ${ }^{31}$

Further investigation on the seeds of this plant led to isolation of ananonins A-N (15-28). Ananonin M (27) was shown to exhibit moderate neuroprotective effects in an in vitro assay. ${ }^{32}$ The dibenzocyclooctadiene lignans polysperlignans A-K (29-39) were isolated from the stems of Kadsura polysperma. Polysperlignans A, B, D and E showed statistically significant neuroprotective effects against $\beta$-amyloid or hydrogen peroxideinduced neurotoxicity on PC12 cells. ${ }^{33}$

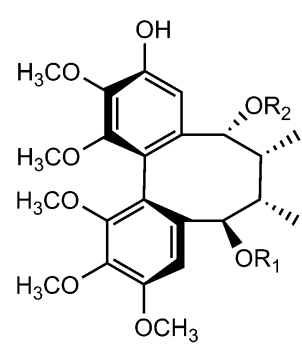

25: $R_{1}=A c, R_{2}=A c$ 26: $R_{1}=A n g, R_{2}=A c$ 27: $R_{1}=B z, R_{2}=H$ 28: $R_{1}=B z, R_{2}=A c$<smiles>[R10]Oc1c2cc(c(OC)c1OC)[C@@H](C)[C@H](C)[C@H](C)[C@H](O)c1cc3c(c(OC)c1-2)OCO3</smiles>

35: $R_{1}=$ OAng 36: $R_{1}=$ OTig

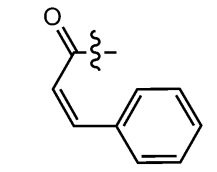

$c$-Cin $=$ cis-Cinnamoyl

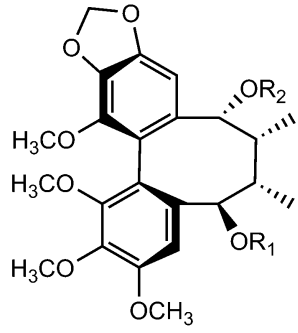

29: $R_{1}=$ Ang, $R_{2}=$ Ang

30: $R_{1}=A c, R_{2}=$ Tig

31: $R_{1}=B z, R_{2}=$ Tig

32: $R_{1}=$ Ang, $R_{2}=$ Tig,

33: $\mathrm{R}_{1}=t$-Cin, $\mathrm{R}_{2}=$ Ang

34: $\mathrm{R}_{1}=\mathrm{H}, \mathrm{R}_{2}=c-\mathrm{Cin}$

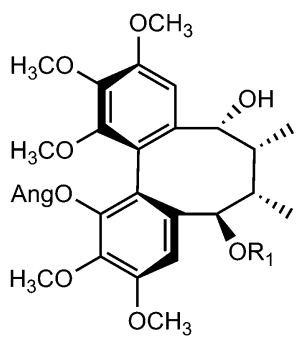

37: $\mathrm{R}_{1}=$ Ang

38: $R_{1}=$ Tig

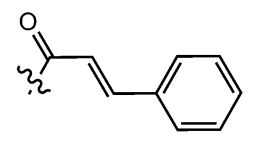

$t$-Cin $=$ trans - Cinnamoyl
Chemical investigation of the $70 \%$ aqueous acetone extract of leaves and stems of Schisandra wilsoniana led to the isolation of marlignans A-L (40-51). ${ }^{34}$ These compounds were evaluated for their anti-HIV activities, in which marlignans C, E, H, and L showed moderate activities with therapeutic index values of 13 , 16, 18, and 16, respectively. Schisanwilsonins A-C (52-54), D 
(57), E (55), F (56) and G (58) have been reported from the same plant species originating from the Yunnan province in People's Republic of China. ${ }^{35}$ More recently, Yang et al. ${ }^{36}$ investigated the fruits of $S$. wilsoniana that further led to the isolation of the dibenzocyclooctadiene lignans, marlignans M-S (59-65). Their cytotoxicity was measured in addition to determining their antiviral activity, using AZT as a positive control $\left(\mathrm{EC}_{50}=0.0043\right.$ $\mu \mathrm{g} \mathrm{mL}^{-1}$ and $\mathrm{CC}_{50}>200 \mu \mathrm{g} \mathrm{mL}^{-1}$ ). They showed anti-HIV-1 activity with $\mathrm{EC}_{50}$ values in the range $3-6 \mu \mathrm{g} \mathrm{mL}^{-1}$ and therapeutic index (TI) values of 5-23. ${ }^{36}$<smiles>COc1cc2c(c(OC)c1OC)-c1c(cc3c(c1OC)OCO3)[C@@H](O)[C@H](C)[C@H](C)C2</smiles><smiles>COc1cc2c(c(O)c1OC)-c1c(cc(O)c(OC)c1O)C[C@@H](C)[C@H](C)C2</smiles><smiles>COc1cc2c(c(O)c1O)-c1c(cc(OC)c(OC)c1O)C[C@@H](C)[C@@H](C)C2</smiles><smiles>[R20][C@H]1c2cc(O)c(OC)c(OC)c2-c2c(cc(O)c(OC)c2OC)C[C@@H](C)[C@@H]1C</smiles>

43: $\mathrm{R}=\mathrm{H}$ 44: $\mathrm{R}=\mathrm{AC}$ 45: $\mathrm{R}=\mathrm{CH}_{3}$ 46: $\mathrm{R}=\mathrm{Bz}$<smiles>COc1c(O)cc2c(c1OC)-c1c(cc(O)c(OC)c1OC)C(=O)[C@H](C)[C@@H](C)C2</smiles>

With an aim to discover bioactive secondary metabolites from the fruits of Schisandra chinensis (Turcz.) Baill, Sun and coworkers isolated seven new $\mathrm{C}_{18}$-dibenzocyclooctadiene lignans, schinlignans $A-G$ 66-72. ${ }^{37}$ Schinlignan $A$ is a $\mathrm{C}_{18^{-}}$ dibenzocyclooctadiene lignan with an ester linkage structurally related to gomisin $\mathrm{D}$ that was previously isolated from the same species and whose absolute structure had been determined by X-ray diffraction analysis. ${ }^{38}$ Schinlignan $G$ exhibited potent antihepatitis B viral activity against HBV DNA replication with $\mathrm{IC}_{50}$ values of $5 \mu \mathrm{g} \mathrm{mL}{ }^{-1}$. Schisandra propinqua is used in Chinese folk medicine for the treatment of arthritis, traumatic injury, gastralgia, angeitis, and related diseases.

Tiegusanins A-M (73-85) are constituents of the aerial parts of this plant. ${ }^{39}$ The isolated compounds were tested for their<smiles>[R2][C@H]1c2cc(OC)c(OC)c(OC)c2-c2c(cc(OC)c(OC)c2OC)C[C@H](C)[C@@H]1C</smiles>

48: $R=A c$

49: $R=E t$<smiles>COc1c(O)cc2c(c1OC)-c1c(cc(O)c(OC)c1OC)C[C@@](C)(O)[C@H](C)C2</smiles><smiles>[R9][C@H]1c2cc(OC)c(OC)c(OC)c2-c2c(cc(O)c(OC)c2OC)C[C@@H](C)[C@@]1(C)O</smiles><smiles>COc1cc2c(c(O)c1OC)-c1c(cc(O)c(OC)c1OC)C[C@@H](C)[C@@](C)(O)C2</smiles>

50<smiles>COc1cc2c(c(OC)c1OC)-c1c(cc3c(c1OC)OCO3)C[C@@H](C)[C@](C)(O)[C@@H](O)[C@H]2O</smiles>

52: $\mathrm{R}=$ Ang 53: $\mathrm{R}=\mathrm{Tig}$

54: $R=B z$ 55: $R=$ Isobut 56: $R=A c$<smiles>COc1cc2c(c(OC)c1O)-c1c(cc(OC)c(O)c1OC)[C@@H](O)[C@H](C)[C@@H](C)C2</smiles>

59 ability to prevent the cytopathic effects of HIV-1 in C8166 cells, and their cytotoxicity was measured in parallel with the determination of antiviral activity, using AZT as a positive control. Tiegusanin G showed anti-HIV-1 activity with an $\mathrm{EC}_{50}$ value of 8 $\mu \mathrm{M}$ and a therapeutic index (TI) of more than 25 .

Neglignans A (86), B (87), and E-G (88-90) were isolated from the acetone extract of the stem of Schisandra neglecta. Neglignans $\mathrm{A}$ and $\mathrm{B}$ are the first dibenzocyclooctadiene lignans bearing a carboxyl group at C-4. ${ }^{40}$ Neglignans B and F showed anti-HIV-1 activities with therapeutic index values greater than 50. Further phytochemical investigation of $S$. neglecta using RPHPLC led to the isolation and characterization of neglectalignans A-D (91-94), which showed moderate anti-HIV-1 activities with therapeutic index values above 62, 23, 58, and 28, respectively. ${ }^{41}$ Neglschisandrins E (95) and F (96) were reported by Chen et al. ${ }^{18}$ as constituents of $S$. neglecta. Compound 96, which possesses an endocyclic double bond rather than the exocyclic bond found in neglschisandrin $\mathrm{B}^{42}$ exhibited marginal cytotoxicity against the human lung carcinoma A549

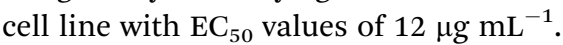

Arisanschinins F-L (97-103), characterized from the fruits of the Taiwanese medicinal plant Schisandra arisanensis, showed moderate in vitro inhibition of proliferation of peripheral blood 
<smiles>COc1cc2c(c(O)c1O)-c1c(cc(OC)c(OC)c1OC)[C@H](O)[C@H](C)[C@H](C)C2</smiles>

60<smiles>COc1c2c(cc3c1-c1c(cc4c(c1O)OCO4)C[C@@H](C)[C@H](C)[C@H]3OC)OCO2</smiles><smiles>COc1cc2c(c(O)c1OC)-c1c(cc3c(c1OC)OCO3)[C@@H](OC)[C@@H](C)[C@H](C)C2</smiles>

64<smiles>COc1c(O)cc2c(c1OC)-c1c(cc3c(c1OC)OCO3)C[C@@H](C)[C@H](C)[C@H]2O</smiles>

61<smiles>COc1c2c(cc3c1-c1c(cc4c(c1O)OCO4)C[C@@H](C)[C@H](C)[C@H]3OC)OCO2</smiles>

63<smiles>COc1cc2c(c(O)c1OC)-c1c(cc3c(c1O)OCO3)[C@@H](OC)[C@@H](C)[C@@H](C)C2</smiles>

65

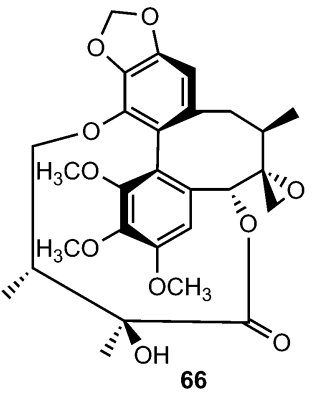<smiles>COc1cc2c(c(OC)c1OC)-c1c(cc(OC)c(OC)c1OC)C[C@](C)(O)[C@H](C)C2</smiles>

68<smiles>COc1cc2c(c(OC)c1OC)-c1c(cc3c(c1OC)OCO3)C[C@@H](C)[C@@](C)(O)C2</smiles>

70<smiles>COc1cc2c(c(OC)c1OC)-c1c(cc3c(c1OC)OCO3)C[C@@H](C)[C@](C)(O)[C@@H](O)[C@H]2O</smiles>

67<smiles>COc1cc2c(c(OC)c1OC)-c1c(cc3c(c1OC)OCO3)C[C@@H](C)[C@@](C)(O)C2</smiles>

69<smiles>COc1cc2c(c(O)c1OC)-c1c(cc(OC)c(OC)c1OC)C[C@@H](C)[C@@](C)(O)C2</smiles>

71 mononuclear cells (PBMC) induced by phytohemaglutinin (PHA). ${ }^{43}$ The EtOAc extract of fruits of Schisandra chinensis (Turcz.) Baill yielded four new dibenzocyclooctadiene lignans, namely schisanchinins A-D (104-107). The stereochemistry of the chiral centers and the biphenyl configuration were determined using NOESY, as well as analysis of CD spectra. Compounds 104 and 105 inhibited NO release by LPS-activated microglia cells. ${ }^{44}$ Schisandrosides A-D (108-111) were also isolated from $S$. chinensis. Although they demonstrated no cytotoxicity against endometrial cancer cells using 3-4,5dimethylthiazol-2-yl-2,5-diphenyltetrazolium bromide (MTT) assays, they represent the first examples of natural dibenzocyclooctadiene lignan glucosides. ${ }^{45}$

Phytochemical examination of the leaves and stems of Schisandra lancifolia led to the isolation of three new dibenzocyclooctadiene lignans, schilancifolignans A-C (112-114), ${ }^{46}$ which exhibited weak anti-HIV-1 activity with therapeutic index values of 8, 12 and 7, respectively. Kadsuphilols I-M (115-119) are among the lignans obtained from the aerial parts of Kadsura philippinensis Elmer by column chromatography using normal and reversed phase HPLC. Their structures were determined by analysis of spectroscopic data, CD spectra, as well as by X-ray analysis. ${ }^{17}$ Kadsuphilol $\mathbf{M}$ is a C19-homolignan with a spirobenzofuranoid skeleton. These compounds exhibited moderate in vitro radical scavenging activities on DPPH.
14-O-Demethyl polysperlignan D (120) was obtained from the EtOAc soluble fraction of the methanol extract of the roots of Kadsura coccinea ${ }^{47}$ Gymnothelignans L (121) and M (122) are epimers containing a $7,7^{\prime}$-epoxide that were isolated from Gymnotheca chinensis (Saururaceae). ${ }^{48}$ A related compound, manglisin B (123), recently isolated from the mature carpels of Manglietiastrum sinicum (Magnoliaceae), was shown to exhibit antimicrobial activities against Staphylococcus aureus, MRSA $82^{\#}$, MRSA $92^{\#}$, MRSA $98^{\#}$, and MRSA $331^{\#}$ with MIC of 0.07 , $0.14,0.07,0.03$ and $0.14 \mu \mathrm{M}$, respectively. ${ }^{49}$

From the dichloromethane extracts of aerial parts of Talauma gloriensis and Magnolia fraseri (Magnoliaceae), five new dibenzocyclooctadiene-type lignans containing a 7,9'-epoxy2,2'-cyclolignane skeleton, were isolated. By using NMR spectroscopy, mass spectrometry, experimental and calculated circular dichroism (CD) and as well as by X-ray crystallography analysis, their structures were elucidated as $(R a)-3,3^{\prime}, 4,4^{\prime}, 5,5^{\prime}$ hexamethoxypyramidatin (124), (Ra)-3, $3^{\prime}$-dimethoxy-4,5, $4^{\prime}, 5^{\prime}$ -

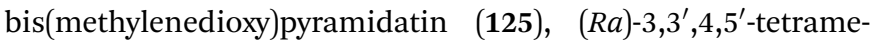
thoxy-4,5-methylenedioxypyramidatin (126), and $(R a)-3,3^{\prime}, 4,5-$ tetramethoxy- $4^{\prime}, 5^{\prime}$-methylenedioxypyramidatin (127) and $(\mathrm{Sa})$ $3,3^{\prime}, 4,5^{\prime}$-tetramethoxy-4,5-methylenedioxypyramidatin $(\mathbf{1 2 8}) .^{50}$ Taiwankadsurin F (129), kadsuphilins N (130) and O (131) were also isolated from $K$. philippinensis. The structure of compound 131 was further confirmed by X-ray crystallographic analysis. ${ }^{51}$ 
<smiles>COc1cc2c(c(OC)c1OC)-c1c(cc(OC)c(OC)c1OC)C[C@@H](C)[C@@H](C)C2</smiles>

72<smiles>COc1cc2c(c(OC)c1OC)-c1c(cc(OC)c(OC)c1OC)[C@H](O)[C@@H](C)[C@H](C)C2</smiles>

75<smiles>[R7]O[C@H]1c2cc(OC)c(OC)c(OC)c2-c2c(cc3c(c2OC)OCO3)[C@H]([R20])[C@@H](C)[C@@H]1C</smiles>

80: $R_{1}=$ Ang, $R_{2}=B z$ 81: $R_{1}=$ Ang, $R_{2}=$ Prop 82: $R_{1}=T i g, R_{2}=T i g$<smiles>CCCCCC(C)=O</smiles>

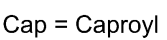<smiles>[R]c1c(OC)c(OC)cc2c1-c1c(cc(OC)c(OC)c1OC)[C@@H](O)[C@H](C)[C@@H](C)C2</smiles>

73: $\mathrm{R}=$ Isoval 74: $\mathrm{R}=$ Isobut

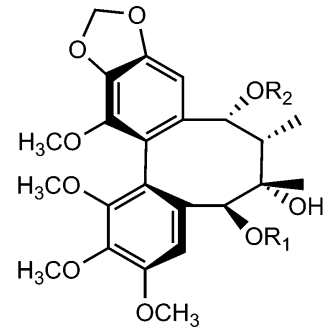

76: $R_{1}=B z, R_{2}=B z$

77: $R_{1}=B z, R_{2}=C a p$

78: $R_{1}=t$-Cin, $R_{2}=B z$

79: $R_{1}=$ Ang, $R_{2}=t$-Cin<smiles>COc1cc2c(c(O)c1OC)-c1c(cc3c(c1O)OCO3)[C@@H](O)[C@@H](C)[C@H](C)[C@H](OC)O2</smiles>

83

In the search of new inhibitors of prostaglandin $\mathrm{E}_{2}$ and leukotriene $\mathrm{B}_{4}$, four derivatives of schisandrin, a major dibenzocyclooctadiene lignan of Schisandra chinensis (Turcz.) Baillon ${ }^{52}$ were synthesized and structurally characterized by means of NMR, mass spectrometry and the axial chirality of the biphenyl system was determined by comparison of calculated with measured CD spectra. ${ }^{53}$ Selective demethylation with 1.1 equivalent of $\mathrm{BBr}_{3}$ (reaction a) turned out to be unsuccessful, because a complex mixture of products was formed, out of which only compounds $\mathbf{1 3 3}$ and 134 could be isolated in pure form. An excess of demethylation reagent ( 6.5 equiv. $\mathrm{BBr}_{3}$ ) led to a more uniform product distribution (reaction $\mathrm{b}$ ) and compound $\mathbf{1 3 2}$ was obtained at $75 \%$ yield. By reaction of 9-iodo-9-bora-bicyclononane (9-I-9-BBN) with schisandrin, a procedure proposed by Fürstner and Seidel $^{54}$ (reaction c), mainly three products were obtained (Scheme 3). Compound 135, in which the ring contraction occurred without any demethylation, alone could be structurally elucidated by NMR. While the original lignan was inactive, compounds 133 and 135 showing the cycloheptadiene skeleton revealed remarkable inhibitory activity on prostaglandin $\mathrm{E}_{2}$ and leukotriene $\mathrm{B}_{4}$ formation in vitro with $\mathrm{IC}_{50}$ values of 4.2 and $4.5 \mu \mathrm{M}$, respectively. ${ }^{53}$<smiles>COc1c(O)cc2c(c1OC)-c1c(cc3c(c1OC)OCO3)C[C@@H](C)[C@H](C)[C@H]2O</smiles>

84<smiles>[R]Oc1c(OC)c(OC)c2c(c1OC)-c1c(cc3c(c1OC)OCO3)[C@@H](O)[C@H](C)[C@@H](C)C2</smiles>

86: $\mathrm{R}=\mathrm{CH}_{3}$ 87: $\mathrm{R}=\mathrm{H}$<smiles>COc1c2cc(c(O)c1OC)C[C@H](C)[C@@H](C)[C@H](O[14CH3])c1cc3c(c(OC)c1-2)OCO3</smiles><smiles>COc1cc2c(c(OC)c1OC)-c1c(cc3c(c1OC)OCO3)C(=O)[C@H](C)[C@@H](C)C2</smiles>

85<smiles>[R]Oc1cc2c(c(OC)c1OC)-c1c(cc(OC)c(OC)c1OC)C[C@@H](C)[C@H](C)[C@H]2OCC(C)C</smiles>

88: $\mathrm{R}=\mathrm{CH}_{3}$ 89: $\mathrm{R}=\mathrm{H}$<smiles>COc1c(O)cc2c(c1O)-c1c(cc(O)c(OC)c1OC)C[C@@H](C)[C@@H](C)C2</smiles>

\subsection{Arylnaphthalene and aryltetralin derivatives}

These important classes of lignans continue to attract the attention of the pharmaceutical industries owing to their remarkable biological activities. The structures of ovafolinins A-E (136-140), isolated from the wood of Lyonia ovalifolia (Ericaceae), were elucidated based on 2D NMR spectroscopy, X-ray crystallography, and chemical methods. Although the isolated compounds did not show cytotoxic activity, ovafolinins A-C (136-138) were determined to be unique aryltetralin lignans containing 7-membered ring formed by the $\mathrm{C} 9-\mathrm{C} 2$ ' ether linkage. Furthermore, ovafolinin D (139) is the first example of a naturally occurring aryltetralin-lignan bearing a methyleneoxy-bridge.$^{55}$ More recently, Kuo et al. ${ }^{56}$ reported (+)-ovafolinin $B-9^{\prime}$ - $O$ - $\beta$-D-glucopyranoside (141), (-)-ovafolinin $B-9^{\prime}-O-\beta-\mathrm{D}-$ glucopyranoside (142), (+)-ovafolinin $E$-9'-O- $\beta$-D-glucopyranoside (143), and (-)-ovafolinin $E$ - $9^{\prime}-O-\beta$-D-glucopyranoside (144) the stems of Eurya japonica (Theaceae). Compounds 141 and 142 demonstrated potent antioxidant activities $\left(\mathrm{ED}_{50} 23\right.$ and 25, respectively) compared to the positive control $\alpha$-tocopherol $\left(\mathrm{ED}_{50} 27 \mu \mathrm{M}\right)$.

The roots of Pycnanthus angolensis (Myristicaceae) afforded four new cyclolignene derivatives, named pycnanthulignenes A$\mathrm{D}$ (145-148). ${ }^{57}$ Pycnanthulignenes $\mathrm{A}$ and $\mathrm{C}$ showed moderate antimicrobial activities against a panel of drug-resistant 
<smiles>COc1cc2c(c(O)c1OC)-c1c(cc(OC(C)=O)c(OC)c1O)C[C@@H](C)[C@@H](C)C2</smiles><smiles>CCO[C@H]1c2cc(O)c(OC)c(OC)c2-c2c(cc(O)c(OC)c2OC)C[C@H](C)[C@@H]1C</smiles><smiles>COc1cc2c(c(OC)c1O)-c1c(cc3c(c1OC)OCO3)C[C@@H](C)[C@H](C)[C@H]2O</smiles>

94<smiles>COc1cc2c(c(OC)c1OC)-c1c(cc(OC)c(OC)c1OC)C[C@@H](C)C(C)=C2</smiles>

96
93

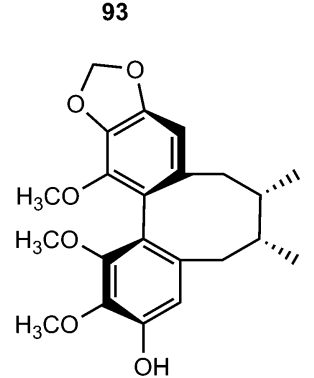

95<smiles>COc1cc2c(c(O)c1OC)-c1c(cc(O)c(OC)c1OC)C[C@@H](C)[C@@H](C)C2</smiles>

97

pathogens with an MIC of $29 \mu \mathrm{M}$ for pycnanthulignene A against Staphylococcus aureus and $64 \mu \mathrm{M}$ for pycnanthulignene C against $S$. aureus, Escherichia coli, and Candida albicans. Bioassay-guided purification of the $\mathrm{CH}_{2} \mathrm{Cl}_{2}$ extract from the fruits of Cleistanthus indochinensis (Euphorbiaceae) afforded two aryltetralin lignans, cleistantoxin (149) and neocleistantoxin (150). ${ }^{58}$ These compounds were evaluated for their cytotoxicity. Cleistantoxin had strong activity against $\mathrm{KB}\left(\mathrm{IC}_{50}\right.$ $0.02 \mu \mathrm{M}), \mathrm{MCF}-7\left(\mathrm{IC}_{50} 0.04 \mu \mathrm{M}\right), \mathrm{MCF}-7 \mathrm{R}\left(\mathrm{IC}_{50} 0.01 \mu \mathrm{M}\right)$, and HT29 $\left(\mathrm{IC}_{50} 0.03 \mu \mathrm{M}\right)$ cancer cell lines while neocleistantoxin had only moderate cytotoxicity. The structure of cleistantoxin is similar to that of podophyllotoxin, which is well-known for its antiviral and antitumor properties. ${ }^{59}$

Four new arylnaphthalene lignans (151-154) were isolated from the aerial parts of Acanthus mollis (Acanthaceae) during its flowering season. Owing to the axial chirality, their structures, including absolute configurations, were determined by means of extensive spectroscopic data and computational chiroptical methods. Compounds 152-154 showed significant inhibition of the growth of crown gall tumors on potato disks. Furthermore, they exhibited significant antiproliferative activity against Paracentrotus lividus. ${ }^{60}$

Sun et $a l .{ }^{61}$ obtained the aryltetralin lignans, 4-acetyl-4demethyl-podophyllotoxin (155), sinolignan A (156) and sinolignan B (157) from the roots and rhizomes of Sinopodophyllum

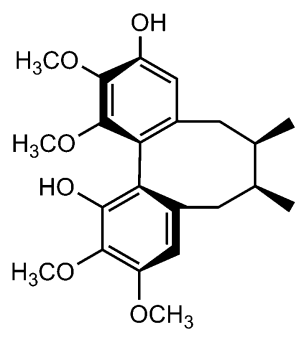

98<smiles>COc1cc2c(c(O)c1OC)-c1c(cc3c(c1OC)OCO3)C[C@@H](C)[C@](C)(O)[C@H]2O[Na]</smiles>

100<smiles>[R][C@@]1(O)c2cc(OC)c(OC)c(O)c2-c2c(cc3c(c2OC)OCO3)C[C@@H]1C</smiles>

102: $R=B z$ 103: $\mathrm{R}=\mathrm{Tig}$<smiles>COc1cc2c(c(O)c1OC)-c1c(cc3c(c1O)OCO3)[C@@H](O)[C@](C)(O)[C@@H](C)C2</smiles>

99<smiles>COc1cc2c(c(OC)c1OC)-c1c(cc(O)c(OC)c1OC)C[C@H](C)[C@@](C)(O)[C@@H]2O[14C](=O)O</smiles>

101<smiles>C=C1c2cc3c(c(OC)c2-c2c(cc(OC)c(OC)c2OC)C[C@H]1C)OCO3</smiles>

104 emodi (Berberidaceae). ${ }^{61}$ Compound 155 showed potent cytotoxicity against Hela and $\mathrm{KB}$ cell lines with $\mathrm{IC}_{50}$ values of 0.08 and $0.05 \mu \mathrm{M}$, respectively. Sargentodosides A-C (158-160) were isolated from ethanol extracts $(60 \%)$ of Sargentodoxa cuneata (Lardizabalaceae) together with a couple of racemic mixtures constituting sargentodognans $F$ (161) and G (162) bearing tyramine moieties. ${ }^{62}$ The aryltetralin-type lignan glycosides 163 and 164, isolated from the branches of Tabebuia chrysotricha (Martius ex De Candolle) Standley (Bignoniaceae), showed moderate DPPH radical-scavenging activity ( $\mathrm{IC}_{50}$ of 44 and 35 $\mu \mathrm{M}$, respectively) compared to Trolox used as a positive control $\left(\mathrm{IC}_{50}\right.$ of $\left.17 \mu \mathrm{M}\right){ }^{63}$

Other aryltetralin lignans include compound 165 and its methyl ether analog 166 isolated from Holostylis reniformis (Aristolochiaceae) $^{64}$ and the aryltetrahydronaphthalene (+)-cycloolivil formaldehyde condensate (167) obtained from the whole plants of Epimedium brevicornum (Berberidaceae) $.^{65} 4,5-$ Didemethylpodophyllotoxin $\quad 7^{\prime}-O-\beta$-D-glucopyranoside (168), one of the constituents of the $n$-butanol extract of roots and rhizomes of Sinopodophyllum emodi, showed in vitro cytotoxicity against four human cancer cell lines (Hela, K562, SH-SY5Y and CNE). ${ }^{66}$ The bark of Machilus robusta (Lauraceae) yielded four new lignans (169-172). ${ }^{25}$ At a concentration of $10 \mu \mathrm{M}, 169$ and 171 reduced DL-galactosamine-induced hepatocyte (WBF344 cells) damage with $77.2 \pm 4.1 \%$ and $64.0 \pm 5.4 \%$ inhibition, 
<smiles>COc1cc2c(c(OC)c1OC)-c1c(cc(O)c(OC)c1OC)C[C@@H](C)[C@@H](C)C2</smiles><smiles>COc1cc2c(c(O)c1OC)-c1c(cc(OC)c(OC)c1OC)C[C@@H](C)[C@@H](C)C2</smiles>

107<smiles>COc1cc2c(c(OC)c1OC)-c1c(cc(OC)c(OC)c1OC)C[C@@H](C)[C@@H](C)C2</smiles>

109<smiles>COc1cc2c(c(OC)c1OC)-c1c(cc(OC)c(OC)c1OC)C[C@@]1(C)O[C@]1(C)C2</smiles><smiles>COc1cc2c(c(OC)c1OC)-c1c(cc3c(c1OC)OCO3)C[C@@H](C)[C@H](O)C2</smiles><smiles>COc1c(O)c(OC(C)(O)F)cc2c1-c1c(cc3c(c1OC)OCO3)C[C@@H](C)[C@@H](C)C2</smiles>

110

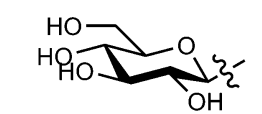

$\mathrm{Glc}=\beta-\mathrm{D}-$ glucopyranosyl respectively, while the positive control bicyclol gave a $67.0 \pm$ $4.6 \%$ inhibition.

Omar et al. ${ }^{67}$ published the first example of a lignan galloyl ester $(+)-2 \alpha$-O-galloyl lyoniresinol $3 \alpha-O-\beta$-D-xylopyranoside (173) from sapwood of Quercus mongolica var. crispula (Fagaceae). The structures and absolute configurations of lignan glycosides 174-178, recently isolated from the aerial parts of Lespedeza cuneata (Leguminosae), were elucidated on the basis of spectroscopic analyses. These compounds were tested for their antiulcerative colitis activity by dual luciferase report gene assay targeting $x b p 1$. Compounds 174, 176 and 178 could activate the transcription of $x b p 1$ to varying degrees with $\mathrm{EC}_{50}$ values of 0.17 $\pm 0.06,0.25 \pm 0.05$, and $0.12 \pm 0.03 \mu \mathrm{M}$, respectively. ${ }^{68}$

Arisantetralones A-D (179-182) are among the lignans isolated from the fruits of Schisandra arisanensis. ${ }^{43}$ The structure and stereochemistry of Arisantetralone A were confirmed by X-ray crystallographic analysis. Arisantetralone D exhibited significant inhibition of proliferation of peripheral blood mononuclear cells (PBMC) induced by phytohemaglutinin (PHA). The aryltetralin type lignan glycosides $55^{\prime}$-methoxy-(+)-isolariciresinol-4'-O- $\beta$-Dglucopyranoside (183), $5^{\prime}$-methoxy- $8^{\prime}$-hydroxyl-(+)-isolariciresinol-<smiles>COc1cc2c(c(OC)c1OC)-c1c(cc3c(c1OC)OCO3)C[C@H](C)[C@](C)(O)[C@H](O[18O])O2</smiles>

111<smiles>COc1cc2c(c(O)c1OC)-c1c(cc(OC)c(OC)c1OC)[C@H](O)[C@@H](OC(C)=O)[C@H](C)[C@H](C)[C@H]2O</smiles><smiles>COc1cc2c(c(O)c1OC)-c1c(cc3c(c1OC)OCO3)[C@@H](O)[C@@H](C)[C@H](O)[C@H](C)[C@H]2OC(C)(C)C</smiles>

117<smiles>[R]c1cc2c(c(OC)c1OC)-c1c(cc3c(c1OC)OCO3)C([R2])[C@@H](C)[C@@H](C)C2</smiles>

112: $\mathrm{R}_{1}=\mathrm{OCH}_{3}, \mathrm{R}_{2}=\mathrm{OCH}_{3}$ 113: $\mathrm{R}_{1}=\mathrm{OH}, \mathrm{R}_{2}=\mathrm{OCH}_{3}$ 114: $\mathrm{R}_{1}=\mathrm{OH}, \mathrm{R}_{2}=\mathrm{OAC}$<smiles>COc1cc2c(c(O)c1OC)-c1c(cc(OC)c(OC)c1OC)[C@H](OC)[C@@H](O)[C@H](C)[C@H]2OC(C)C</smiles><smiles>COc1cc2c(c(OC)c1OC)-c1c(cc3c(c1O)OCO3)[C@@H](O)[C@@H](C)[C@@H](O)[C@H](O)[C@H]2OC(C)=O</smiles>

118

4'-O- $\beta$-D-glucopyranoside (184), 5-methoxy-(+)-isolariciresinol-4'$O$ - $\beta$-D-glucopyranoside (185), and $8^{\prime}$-hydroxy- $(+)$-isolariciresinol-9$O$ - $\beta$-D-xylopyranoside (186) were isolated from the roots of $R h o$ diola crenulata (Crassulaceae). ${ }^{69}$

Pronaphthalide A (187), procumbenoside J (188) and juspurpudin (189) are two lignans and a secolignan from Justicia procumbens L. (Acanthaceae). ${ }^{70}$ Procumbenoside contains an apiofuranosyl acetonide residue in its structure. In its ${ }^{1} \mathrm{H}$ NMR spectrum, some signals existed as pairs due to the equilibrium between two conformational isomers resulting from the slow rotation of the sugar unit at room temperature around the glucosidic linkage with the aglycone. Juspurpudin is a rare type of secolignan, being part of a group of only a few other similar compounds reported so far. ${ }^{71}$ Its biosynthesis was suggested to occur via a typical lignan derivative taiwanin C, also isolated from the same plant (Scheme 4). It was proposed that taiwanin C could be transformed to an intermediate which shared a structural similarity with podophyllotoxin by the process of ring $\mathrm{B}$ reduction and benzylic oxidation. The following $\mathrm{C}-\mathrm{C}$ bond cleavage in the intermediate and formation of $\alpha, \beta$-unsaturated- $\gamma$-lactone would lead to juspurpudin. Compounds 187 and 188 exhibited potent cytotoxic activities in vitro against 


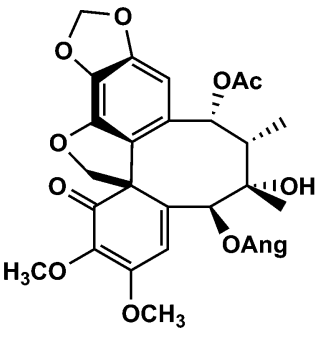

119

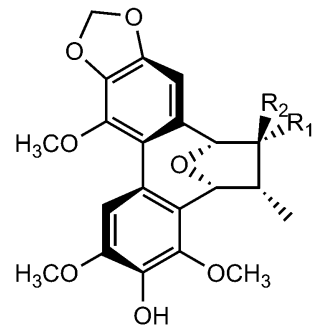

121: $\mathrm{R}_{1}=\mathrm{CH}_{3}, \mathrm{R}_{2}=\mathrm{H}$

122: $R_{1}=H, R_{2}=\mathrm{CH}_{3}$<smiles>COc1cc2c(c(OC)c1OC)-c1c(cc(OC)c(OC)c1OC)[C@H]1O[C@H](C2)[C@H]1C</smiles>

124<smiles>[CH]O[C@H]1c2cc(OC)c(OC)c(OC)c2-c2c(cc3c(c2O)OCO3)[C@@H]([18O])[C@H](C)[C@@H]1C</smiles>

120<smiles></smiles>

123

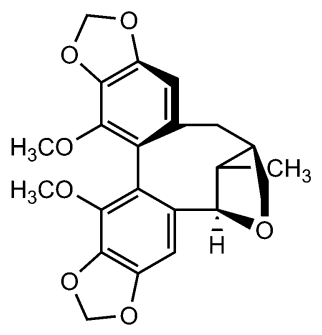

125<smiles>COc1cc2c(c(OC)c1OC)-c1c(cc3c(c1OC)OCO3)[C@@H]1O[C@H]2CC[C@@H]1C</smiles><smiles>COc1cc2c(c(OC)c1OC)O[C@H]1C[C@H]2[C@@H](C)[C@H]1O</smiles>

128

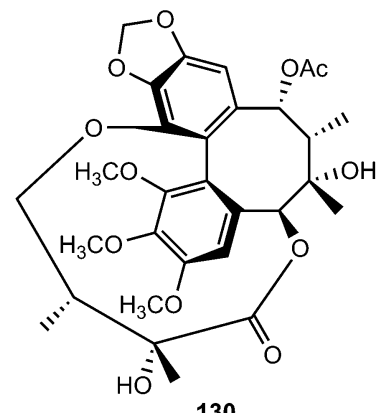

130<smiles>COc1cc2c(c(OC)c1OC)-c1c(cc3c(c1OC)OCO3)C[C@@H]1C[C@H]2O[C@H]1C</smiles>

127

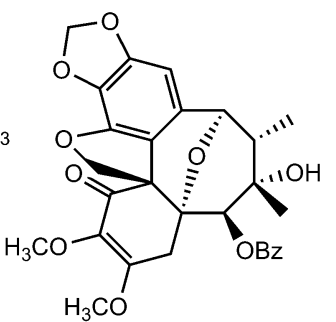

129<smiles>COC1=C(OC)C(=O)[C@@]2(C(=O)C1=O)c1c(cc3c(c1OC)OCO3)[C@@H](O)[C@]1(C)O[C@]12C</smiles>

131 sensitive human LoVo and BGC-823 cell lines with IC $_{50}$ values in the range of 0.11 to $0.53 \mu \mathrm{M}^{70}$

Linderanosides A (190) and B (191), isolated from the trunk of Lindera glauca (Lauraceae), had selective cytotoxicity against A498 cells, with $\mathrm{IC}_{50}$ values of 21 and $22 \mu \mathrm{M}$, respectively. ${ }^{72}$ A bioassay-guided fractionation and chemical investigation of the methanolic extract of Tilia amurensis Rupr. (Tiliaceae) trunk resulted in the isolation and identification two new lignan glycosides named tiliamurosides A (192) and B (193). Tiliamuroside B showed significant cytotoxicity against A549, SK-OV-3, SK-MEL-2, and HCT-15 cell lines with inhibitory concentration $\left(\mathrm{IC}_{50}\right)$ of $7.3,8.9,7.8$ and $6.2 \mu \mathrm{M}$, respectively. ${ }^{73}$

Saurunarin (194) is one of the previously unreported lignans from the aerial parts of Saururus chinensis (Saururaceae). ${ }^{74}$ Phytochemical investigation of the extracts from the leaves and twigs of Euonymus alatus (Celastraceae) having antihyperglycaemic, hyperlipidaemic and immune-stimulating activities $^{75}$ led to the isolation and structure elucidation of $\left(7 R, 8 R, 7^{\prime} R\right)-(+)$-lyoniresinol (195).$^{76}$ Saposide A (196), isolated from the maple sap of Acer saccharum (Aceraceae), showed moderate antioxidant activity on superoxide dismutase. ${ }^{77}$ The structure of the arylnaphthalene lignan lactone glycoside 7-O[(3,4-di-O-acetyl)- $\alpha$-L-arabinopyranosyl] diphyllin (197) obtained from Phyllanthus poilanei (Phyllanthaceae), together with 7-O[(3-O-acetyl)- $\alpha$-L-arabinopyranosyl]-diphyllin (198), was confirmed by analysis of its single-crystal X-ray diffraction data. These compounds exhibited cytotoxic activities against the HT29 cells with $\mathrm{IC}_{50}$ values of 0.17 and $1.8 \mu \mathrm{M}$, respectively. ${ }^{78}$ The lignan ester 199 was isolated from the leaves of Dodecadenia grandiflora (Lauraceae) and is believed to be derived from dimerization of two phenylpropanoyl esters of catechol glycoside units. ${ }^{79}$ It showed significant antihyperglycemic activity in streptozotocin-induced (STZ) diabetic rats, which is comparable to the standard drug metformin. ${ }^{79}$

The well-known ability of Cunninghamella echinulata to hydroxylate benzylic positions of aromatic substrates ${ }^{\mathbf{8 0}}$ prompted Messiano et $a l .{ }^{\mathbf{8 1}}$ to investigate the metabolism of aryltetralin lignans by this fungus. To this end, the aryltetralin lignan (-)-isogalbulin (200) was obtained in high overall yield by the treatment of (-)-8'-epi-aristoligone (201) with $\mathrm{NaBH}_{4} /$ methanol followed by hydrogenolysis $\left(\mathrm{H}_{2} / 10 \% \mathrm{Pd}\right.$ on $\left.\mathrm{C} / \mathrm{EtOH}\right)$. When 200 was incubated with $C$. echinulata for 20 days, the EtOAc extract of the resulting culture broth afforded seven new metabolites: (-)-8hydroxyisogalbulin (202), (-)-7-methoxyisogalbulin (203), (-)-4'$O$-demethyl-8-hydroxyisogalbulin (204), (-)-7-methoxy-8-hydroxyisogalbulin (205), (-)-4'-O-demethyl-7-methoxyisogalbulin (206), 
<smiles>CC(O)C1(C)Cc2cc(O)c(O)c(O)c2-c2c(cc(O)c(O)c2O)C1</smiles>

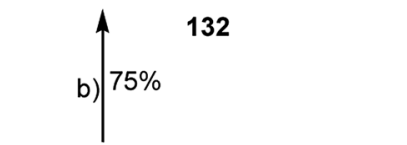<smiles>COc1cc2c(c(OC)c1OC)-c1c(cc(OC)c(OC)c1OC)C[C@](C)(O)[C@H](C)C2</smiles><smiles>COc1cc2c(c(OC)c1OC)-c1c(cc(OC)c(OC)c1OC)CC(C)(C(C)I)C2</smiles>

Scheme 3 Chemical modification of schisandrin. Reaction conditions: (a) 1.1 equiv. $\mathrm{BBr}_{3}$; (b) 6.5 equiv. $\mathrm{BBr}_{3}$; (c) 5.3 equiv. 9-iodo-9-BBN, $\mathrm{CH}_{2} \mathrm{OHCH}_{2} \mathrm{NH}_{2}$.

(-)-4',5-O-didemethylcyclogalgravin (207), and (-)-4'-O-demethylcyclogalgravin (208).

Podophyllotoxin has been in use for a while for treating venereal warts and also serves as an important precursor for the preparation of clinical antitumor drugs etoposide and teniposide. ${ }^{82,83}$ A growing worldwide demand for podophyllotoxin has exerted severe pressure on the plant resource. Wu and coworkers have reported a highly flexible and concise total synthesis of (+)-podophyllotoxin featured with an enantioselective sequential conjugate addition-allylation reaction. Starting from commercially available 3,4,5-trimethoxycinnamic acid, this new route leads to (+)-podophyllotoxin in only eight steps with $29 \%$ overall yield. ${ }^{84}$ First, 3,4,5-trimethoxycinnamic acid was converted to its $n$-butylester, and 6-bromopiperonal was treated with (+)-pseudoephedrine and directly converted to oxazolidine 209 as a single diastereoisomer. For Michael addition-alkylation, ${ }^{85}$

$N, N, N^{\prime}, N^{\prime}$-tetramethylethylenediamine

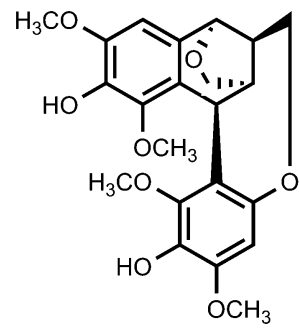

136<smiles>COc1cc2c(c(OC)c1O)[C@H]1c3c(cc(OC)c(O)c3OC)[C@@H]1[C@H]1CO[C@@H](C1)C2=O</smiles>

138<smiles>COc1cc([C@H]2c3c(cc(OC)c(O)c3OC)C=C(C=O)[C@@H]2CO)cc(OC)c1O</smiles>

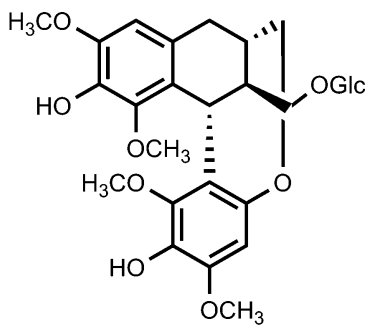

142<smiles>COC[C@@H]1C(C=O)=Cc2cc(OC)c(O)c(OC)c2[C@@H]1c1cc(OC)c(O)c(OC)c1</smiles><smiles>COc1cc2c(c(OC)c1O)[C@H]1c3c(OC)c(O)c(OC)cc3[C@H]3C[C@H](C3)[C@@H]1C(O)O2</smiles>

137<smiles>COc1cc([C@]23OC[C@@H](C[C@H]2O)c2cc(OC)c(O)c(OC)c23)cc(OC)c1O</smiles>

139<smiles>COc1cc2c(c(OC)c1O)[C@@H]1c3c(cc(OC)c(O)c3OC)OC3(OCl)[C@H](C2)C[C@H]3[C@H]1O</smiles>

141<smiles>COc1cc([C@H]2c3c(cc(OC)c(O)c3OC)C=C(C=O)[C@@H]2COCl)cc(OC)c1O</smiles>

143<smiles>COc1cc2c(cc1OC)[C@H](c1ccc(O)cc1)[C@H](C)C(C)=C2</smiles>

(TMEDA), a frequently used solvating agent in organolithium chemistry with observed beneficial effects on stereoselectivity, was added in order to optimize the stereoselectivity and aldehyde $\mathbf{2 1 0}$ was obtained with 65\% yield (Scheme 5). Aldehyde 210 was then submitted to an oxidative cleavage followed by an $\mathrm{L}^{-}$ 
<smiles>COc1cc2c(cc1OC)[C@@H](c1ccc3c(c1)OCO3)[C@H](C)C(C)=C2</smiles>

146<smiles>COc1c2c(c(O)c3c(-c4ccc(O)cc4)c(C)c(C)cc13)OCO2</smiles>

148<smiles>COc1c2c(cc3c1[C@H]1O[C@H](CO)[C@@H](C(=O)[C@H]3O)[C@H]1c1ccc3c(c1)OCO3)OCO2</smiles>

150

$\mathrm{R}_{1}$<smiles>[R20]c1cc2c(cc1C1=C3C(=C(OCC)c4ccc5c(c43)OCO5)COC1=O)OCO2</smiles>

$151 \quad \mathrm{H}$

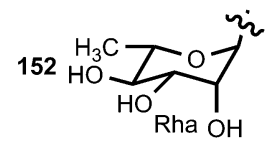

$\mathrm{H}$

153

$\mathrm{H}$
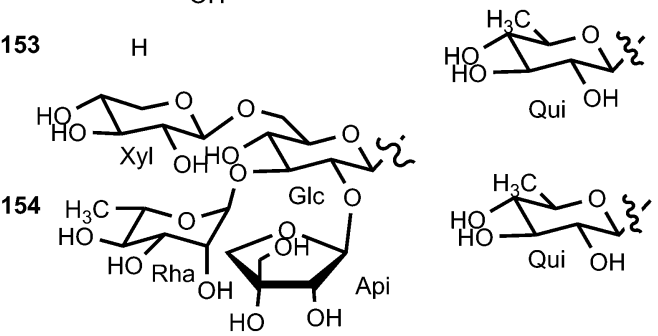

Rha: $\alpha$-L-rhamnopyranosyl

Glc: $\beta$-D-glucopyranosyl

Qui: $\beta$-D-quinovopyranosyl

Api: $\beta$-D-apiofuranosyl

Xyl: $\beta$-D-xylopyranosyl<smiles>COc1cc([C@H]2c3cc4c(cc3[C@@H](O)[C@@H]3COC(=O)[C@@H]23)OCO4)cc(OC)c1OC</smiles><smiles>COc1cc([C@H]2c3cc4c(cc3[C@@H](OC3OCC(O)C(CO)CO3)[C@H]3COC(=O)[C@H]23)OCO4)cc(OC)c1OC</smiles>

155<smiles>COc1cc([C@H]2c3cc4c(cc3[C@@H](O)[C@H]3COC(=O)[C@H]23)OCO4)cc(OC)c1O</smiles>

proline-mediated aldol cyclization and a selective oxidation with $\mathrm{MnO}_{2}$ to afford intermediate 211. After the tert-butyl ester group was hydrolyzed by treatment with hydrochloric acid in acetonitrile, an esterification with DCC provided (+)-podophyllotoxone (212) with around 90\% yield. Selective reduction with L-selectride provided ent-podophyllotoxin (213) with around $98 \%$ yield as a single isomer (Scheme 6).

Many arylnaphthalene lignans are components of traditional herbal remedies and have received increased attention over the past several decades owing to their cytotoxic, ${ }^{86}$ antiviral, ${ }^{87}$ fungicidal, antiprotozoal, and antiplatelet activities in cellbased assays. ${ }^{88,89}$ A silver-catalyzed one-pot synthesis of the arylnaphthalene lactone core using carbon dioxide, phenylpropargyl chloride, and phenylacetylene, previously demonstrated by Foley et al., ${ }^{90}$ was applied to the synthesis of the naturally occurring arylnaphthalene lignans retrochinensin (216), justicidin B (217), retrojusticidin B (218), chinensin (219), justicidin E (220), and taiwanin $C(\mathbf{2 2 1}) \cdot{ }^{91}$ By treating $3,4-$ methylenedioxyphenylpropargyl alcohol and 3,4-dimethoxyphenylpropargyl alcohol with thionyl chloride in $N, N$-dimethylacetamide (DMA), the desired phenylpropargyl chlorides 214a and 214b were generated with $96 \%$ and $84 \%$ yields, respectively. These substituted phenylpropargyl chlorides, together with phenylacetylenes 215a and 215b, could then be taken on to the multicomponent tandem coupling reaction as shown in Scheme 7.

\subsection{Dibenzylbutane, dibenzylbutyrolactol and dibenzylbutyrolactone derivatives}

The EtOAc soluble fraction of methanol extract of the roots of Kadsura coccinea yielded two dibenzylbutane lignans kadsurindutin E (222) and coccilignan A (223), even though their 
<smiles>[R]Oc1cc([C@H]2c3cc(OC)c(OC)cc3C[C@H](CO)[C@@H]2CO)cc([C@H]2c3cc(O)c(OC)cc3C[C@H](CO)[C@@H]2CO)c1OC</smiles><smiles>[R]O[C@H]1c2cc(OC)c(O)cc2[C@@H](c2ccc(OC)c(OC)c2)[C@H](C)[C@@H]1C</smiles><smiles>COc1cc([C@@H]2c3cc(O)c(OC)cc3C[C@]3(O)COCOC[C@H]23)ccc1O</smiles>

167<smiles>COc1cc([C@H]2c3cc4c(cc3[C@@H](OC(C)(F)F)[C@H]3COC(=O)[C@H]23)OCO4)cc(O)c1O</smiles><smiles>[R]C[C@H]1[C@@H](c2ccc(O)c(OC)c2)c2cc(O)c(OC)cc2C[C@H]1CO</smiles>

$\mathrm{R}$

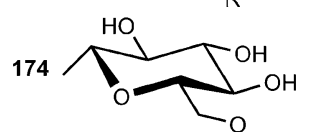<smiles>COc1cc([C@H]2c3cc(O)c(OC)cc3C[C@@H](CO)[C@H]2CO)ccc1O</smiles>

178<smiles>[R]c1cc([C@H]2c3cc(O)c(OC)cc3C[C@H](CO)[C@@H]2CO)cc(OC)c1O</smiles>

176: $\mathrm{R}=\mathrm{H}$ 177: $\mathrm{R}=\mathrm{OCH}_{3}$ 
<smiles>[R20]Oc1ccc([C@H]2c3cc([R20])c([R20])cc3C(=O)[C@@H](C)[C@@H]2C)cc1OC</smiles>

179: $R_{1}=H, R_{2}=\mathrm{CH}_{3}, R_{3}=H$

180: $R_{1}=\mathrm{CH}_{3}, \mathrm{R}_{2}=\mathrm{H}, \mathrm{R}_{3}=\mathrm{H}$

181: $R_{1}=H, R_{2}=C_{3}, R_{3}=C_{3}$<smiles>[R]c1cc([C@H]2c3c(cc(OC)c(O)c3[R])C[C@@]([R7])(CO)[C@@H]2CO)cc(OC)c1O</smiles>

183: $R_{1}=H, R_{2}=O C_{3}, R_{3}=H$

184: $\mathrm{R}_{1}=\mathrm{OH}, \mathrm{R}_{2}=\mathrm{OCH}_{3}, \mathrm{R}_{3}=\mathrm{H}$

185: $R_{1}=H, R_{2}=H, R_{3}=O_{3}$<smiles>COC[C@H]1[C@H](c2ccc(O)c(OC)c2)c2cc(O)c(OC)cc2C[C@@]1(O)CO</smiles>

186<smiles>O=C1OCc2cc3cc4c(cc3c(-c3ccc5c(c3)OCO5)c21)OCO4</smiles>

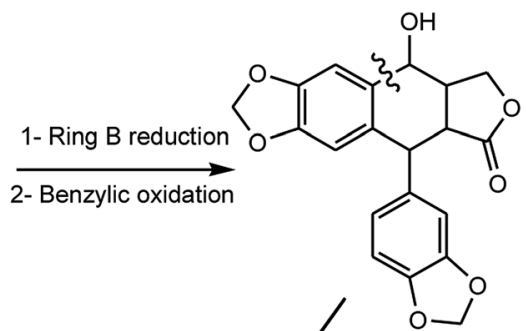

Taiwanin C<smiles>CCOC(=O)C1=C(CO)COC1=O</smiles>

Juspurpudin

Scheme 4 Proposed biogenesis of juspurpudin

absolute configurations remain to be determined. Compound 222 inhibited NO production in BV-2 cells with $\mathrm{IC}_{50}$ value of $24 \mu \mathrm{M} .^{47}$ Saurulignans A-E (224-228) were reported from Saururus chinensis, a Chinese medicinal plant used to cure hepatitis, pneumonia, edema, jaundice, and gonorrhea. ${ }^{74}$ Saurulignan E, characterized by a 2-methoxy1,4-benzoquinone moiety in its structure, showed significant inhibition of adenosine diphosphate-induced aggregation with an $\mathrm{IC}_{50}$ of $10 \mu \mathrm{M}$ and arachidonic acid-induced aggregation with an $\mathrm{IC}_{50}$ of $14 \mu \mathrm{M}$.<smiles>COc1ccc(-c2c3c(c(OC)c4cc(OC)c(OC)cc24)COC3=O)cc1O</smiles>

187<smiles>O=C1OCC(CO)=C1C(c1ccc2c(c1)OCO2)c1ccc2c(c1)OCO2</smiles>

189<smiles>COc1cc([C@H]2c3c(cc(OC)c(O)c3O)C[C@H](CO)[C@@H]2CO)cc(OC)c1O</smiles>

191<smiles>COc1cc([C@H]2c3c(cc(OC)c(O)c3O)C[C@H](CO)[C@@H]2CO)cc(OC)c1O</smiles>

190<smiles>COc1cc([C@H]2c3c(cc(OC)c(O)c3O)C[C@H](CO)[C@@H]2CO)ccc1O</smiles>

192<smiles></smiles>

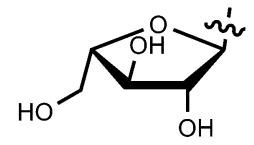

$\alpha$-L-arabinofuranosyl
Magnovatins A (229) and B (230) are secondary metabolites from the leaves of Magnolia ovata (Magnoliaceae). ${ }^{92}$ In order to determine the absolute configuration of these compounds, they were submitted to an acid-catalyzed cyclization, yielding the new lignans 229a and 230a, respectively. CD analysis of the products allowed deduction of the absolute configurations of the substrates given that C-7 undergoes inversion of configuration during the cyclization process ( $\mathrm{SN}_{2}$ mechanism). ${ }^{92} \mathrm{Mag}-$ novatin A was tested for free-radical scavenging activity using DPPH as well as for antimicrobial activity, but was inactive under the tested conditions. Phytochemical investigation of ethanol extract of bark of Machilus robusta (Lauraceae) led to the isolation of eight new lignans (231-238). ${ }^{25}$ Compounds 237 and 238 are uncommon $4^{\prime}, 8^{\prime \prime}$-oxy-8, $8^{\prime}$-sesquilignans that exhibited in vitro activity against HIV-1 replication with $\mathrm{IC}_{50}$ of 2.5 and 2 $\mu \mathrm{M}$, respectively. Furthermore, 231 reduced DL-galactosamineinduced hepatocyte (WBF344 cells) damage at $10 \mu \mathrm{M}$ and could additionally attenuate rotenone-induced PC12 cell damage by increasing the cell viability from $73.0 \pm 9.6 \%$ to $96.2 \pm 15.6 \%$. 
<smiles>COc1cc([C@@H]2c3cc(O)c(OC)cc3C[C@H]2CO)ccc1O</smiles><smiles>C[C@H]1Cc2c(O)cc3c(c2[C@@H](c2ccc4c(c2)OCO4)[C@H]1C)OCO3</smiles><smiles>COc1cc([C@H]2c3c(cc(OC)c(O)c3OC)C[C@H](CO)[C@H]2CO)cc(OC)c1O</smiles><smiles>[3H][Ge]OC[C@H]1[C@@H](CO)Cc2cc(OC)c(O)cc2[C@@H]1c1ccc(O)c(OC)c1</smiles>

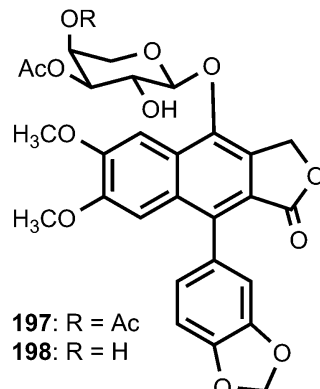
196<smiles></smiles>
199<smiles>[R6]Oc1ccc([C@H]2c3cc(OC)c(OC)cc3C([R])([R])[C@@]([R1])(C)[C@@H]2C)cc1OC</smiles>

200: $R_{1}=R_{5}=C_{3} ; R_{2}=R_{3}=R_{4}=H$

201: $R_{1}=R_{5}=C_{3} ; R_{2}, R_{3}=O, R_{4}=H$

202: $\mathrm{R}_{1}=\mathrm{R}_{5}=\mathrm{CH}_{3} ; \mathrm{R}_{2}=\mathrm{R}_{3}=\mathrm{H}, \mathrm{R}_{4}=\mathrm{OH}$

203: $R_{1}=R_{5}=C_{3} ; R_{2}=R_{4}=H ; R_{3}=O_{3}$

204: $\mathrm{R}_{1}=\mathrm{CH}_{3} ; \mathrm{R}_{2}=\mathrm{R}_{3}=\mathrm{R}_{5}=\mathrm{H} ; \mathrm{R}_{4}=\mathrm{OH}$

205: $\mathrm{R}_{1}=\mathrm{R}_{5}=\mathrm{CH}_{3} ; \mathrm{R}_{2}=\mathrm{H} ; \mathrm{R}_{3}=\mathrm{OCH}_{3} ; \mathrm{R}_{4}=\mathrm{OH}$

206: $\mathrm{R}_{1}=\mathrm{CH}_{3} ; \mathrm{R}_{2}=\mathrm{R}_{4}=\mathrm{R}_{5}=\mathrm{H} ; \mathrm{R}_{3}=\mathrm{OCH}_{3}$

The dibenzylbutane-type lignan 239 and saururin B 240 was identified from the roots of Schisandra sphenanthera ${ }^{93}$ and Saururus chinensis Bail (Saururaceae), ${ }^{94}$ respectively.

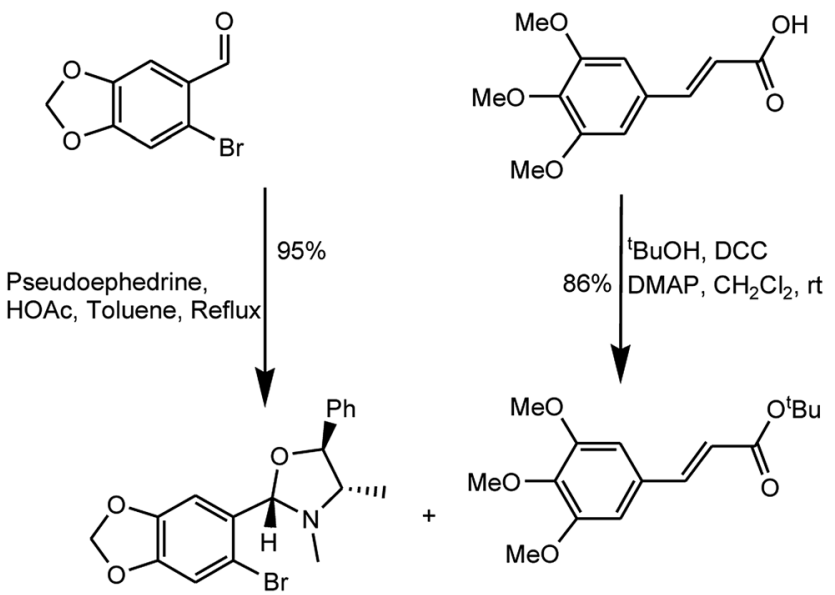

209

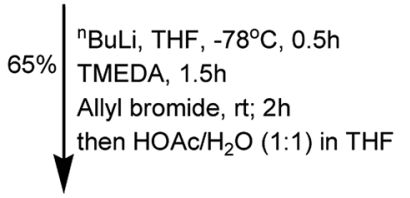<smiles>C=CC[C@H](C(=O)OCCCC)[C@H](c1cc(OC)c(OC)c(OC)c1)c1cc2c(cc1C=O)OCO2</smiles>

210

Scheme 5 Enantioselective sequential Michael addition-alkylation.

Schineolignins A-C (241-243) were isolated from the fruit of Schisandra chinensis and their relative stereochemistry could not be determined on the basis of ROESY spectrum because their $\mathrm{C}-\mathrm{C}$ bonds can rotate randomly. ${ }^{95}$ The substituted 1,4-biphenyl-2,3-dimethylbutane-type lignan tiegusanin N (244) was reported from Schisandra propinqua as a racemate. ${ }^{39}$ The two meso-nordihydroguaiaretic acid glycoside derivatives, larrealignans A (245) and B (246), isolated from Larrea tridentata (Zygophyllaceae), are believed to be the first representatives of lignan tetra- and tri-desmosides, respectively. They did not exhibit cytotoxicity even at a sample concentration of $20 \mu \mathrm{M} .{ }^{96}$ During the investigation of bioactive components of Liriodendron hybrid (Magnoliaceae), a pair of unprecedented enantiomeric lignans, $(+)$ - and (-)-liriodenols bearing a 1,1-disubstituted olefinic group was discovered. The above enantiomers were separated by HPLC to yield $8 R$-liriodenol $(\mathbf{2 4 7})$ and $8 S$-liriodenol (248). ${ }^{97}$ The cytotoxicity of these three lignans $(( \pm)-,(+)-$, and $(-)$-liriodenols) was evaluated in vitro against four selected human tumor cell lines. It was noticed that $(+)$-liriodenol showed more significant cytotoxic effects $\left(\mathrm{IC}_{50}\right.$ of $31,45,34$ and $29 \mu \mathrm{g}$ $\mathrm{mL}^{-1}$ against NIC-H460, BGC-823, SGC-7901 and MDA-MB- 
<smiles>C=CC[C@H](C(=O)OCCC)[C@H](c1cc(OC)c(OC)c(OC)c1)c1cc2c(cc1C=O)OCO2</smiles>

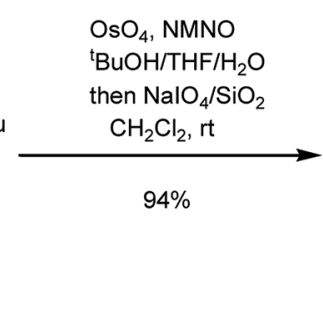

210<smiles>COc1cc([C@@H]2c3cc4c(cc3[C@@H](O)[C@H]3COC(=O)[C@H]23)OCO4)cc(OC)c1OC</smiles>

213<smiles>CCCCC(=O)[C@H](CC=O)[C@@H](c1cc(OC)c(OC)c(OC)c1)c1cc2c(cc1C=O)OCO2</smiles>

L-Proline, $\mathrm{CH}_{2} \mathrm{Cl}_{2}$

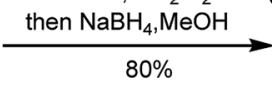<smiles>CCCCC(=O)[C@@H]1c2cc3c(cc2C(O)[C@H](CO)[C@@H]1c1cc(OC)c(OC)c(OC)c1)OCO3</smiles><smiles>COCCN(C)[18OH]</smiles>

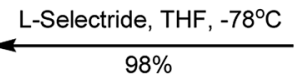<smiles>CCOc1c(OC)cc([C@H]2c3cc4c(cc3C(=O)[C@@H]3COC(=O)[C@H]32)OCO4)cc1OC</smiles>

Scheme 6 Enantioselective sequential Michael addition-alkylation.<smiles>[R20]c1ccc(C#CCC)cc1[R20]</smiles>

214a: $\mathrm{R}_{1}, \mathrm{R}_{2}=\mathrm{CH}_{2}$ 214b: $\mathrm{R}_{1}=\mathrm{R}_{2}=\mathrm{CH}_{3}$<smiles>[R20]Oc1cc2cc3c(c(-c4ccc(O[R20])c(O[R20])c4)c2cc1[R20])COC3=O</smiles>

216: $\mathrm{R}_{1}=\mathrm{CH}_{2}, \mathrm{R}_{2}=\mathrm{CH}_{3}(16 \%)$ 218: $\mathrm{R}_{1}=\mathrm{CH}_{3}, \mathrm{R}_{2}=\mathrm{CH}_{2}(31 \%)$ 220: $\mathrm{R}_{1}=\mathrm{R}_{2}=\mathrm{CH}_{2}(18 \%)$

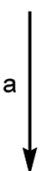<smiles>[R20]c1ccc(C#C)cc1[R20]</smiles>

215a: $\mathrm{R}_{1}, \mathrm{R}_{2}=\mathrm{CH}_{2}$ 205b: $\mathrm{R}_{1}=\mathrm{R}_{2}=\mathrm{CH}_{3}$<smiles>[R20]Oc1ccc(-c2c3c(cc4cc([R20])c([R20])cc24)COC3=O)cc1[R20]</smiles>

217: $\mathrm{R}_{1}=\mathrm{CH}_{3}, \mathrm{R}_{2}=\mathrm{CH}_{2}(16 \%)$

219: $\mathrm{R}_{1}=\mathrm{CH}_{2}, \mathrm{R}_{2}=\mathrm{CH}_{3}(26 \%)$

221: $R_{1}=R_{2}=\mathrm{CH}_{2}(18 \%)$

Scheme 7 Preparation of arylnaphthalene lignans 216-221; ${ }^{a}$ reagents: $\mathrm{SOCl}_{2}, \mathrm{DMA} ; \mathrm{K}_{2} \mathrm{CO}_{3}, 18$-crown-6, $4 \AA$ molecular sieves, DMA, $100{ }^{\circ} \mathrm{C}$.

231 , respectively) than the $( \pm)$ - and (-)-liriodenol. The spatial configuration of lignans in 8-positions might induce different cytotoxic activities on tumor cells.<smiles>COc1cc(CC(C)C(C)Cc2ccc3c(c2)OCO3)cc(O)c1O</smiles>

222<smiles>[R20]Oc1cc([R3])c(C[C@H](C)[C@@H](C)Cc2cc3c(cc2O)OCO3)cc1O[R20]</smiles>

224: $\mathrm{R}_{1}=\mathrm{CH}_{3}, \mathrm{R}_{2}=\mathrm{H}, \mathrm{R}_{3}=\mathrm{H}$

225: $\mathrm{R}_{1}=\mathrm{CH}_{3}, \mathrm{R}_{2}=\mathrm{H}, \mathrm{R}_{3}=\mathrm{OH}$

226: $\mathrm{R}_{1}=\mathrm{CH}_{3}, \mathrm{R}_{2}=\mathrm{CH}_{3}, \mathrm{R}_{3}=\mathrm{OH}$<smiles>COc1cc(CC(C)C(C)C(=O)c2cc(O)c(OC)c(OC)c2)cc(O)c1OC</smiles>

223<smiles>COC1=CC(=O)C(C[C@@H](C)[C@@H](C)Cc2cc3c(cc2O)OCO3)=CC1=O</smiles>

228

The EtOAc phase obtained from a methanol extract of the trunk of Abies holophylla (Pinaceae) exhibited inhibitory effects on NO production in murine microglia BV-2 cells. Successive chromatography through silica gel, Sephadex LH20 , and preparative HPLC of this extract resulted in isolation of three new 9,9'-epoxylignans, holophyllol A-C (249-251). Their structures were determined by spectroscopic methods, CD experiments, acid hydrolysis, and the use of 
<smiles>C[C@H](Cc1ccc2c(c1)OCO2)[C@@H](C)[C@H](O)c1ccc2c(c1)OCO2</smiles><smiles>COc1ccc(C[C@@H](C)[C@H](C)[C@H](O)c2ccc3c(c2)OCO3)cc1OC</smiles>

229

229a: $R_{1}=R_{2}=\mathrm{CH}_{2}$ 230a: $R_{1}=R_{2}=\mathrm{CH}_{3}$

231: $R_{1}=R_{2}=R_{4}=H, R_{3}=O H, R_{5}=O_{3}$ 232: $R_{1}=R_{2}=R_{4}=H, R_{3}=R_{5}=O H_{3}$ 233: $R_{1}=R_{2}=H, R_{3}=R_{5}=O_{3} C_{3}, R_{4}=C_{3}$ 234: $R_{1}=O A c, R_{2}=R_{4}=H, R_{3}=R_{5}=O H_{3}$ 235: $R_{1}=R_{4}=H, R_{2}=O A c, R_{3}=R_{5}=O_{3}$ 236: $R_{1}=R_{2}=R_{3}=R_{4}=R_{5}=H$<smiles>COc1cc(C[C@H](C)[C@@H](C)Cc2cc(OC)c(O[C@@H](C)[C@@H](O)c3ccc(O)c(OC)c3)c(OC)c2)ccc1O</smiles><smiles>COc1cc(O)cc([C@@H](O)[C@H](C)[C@@H](C)Cc2ccc3c(c2)OCO3)c1</smiles>

239<smiles>[R20]Oc1cc2c(cc1O[R20])[C@H](c1ccc3c(c1)OCO3)[C@H](C)[C@@H](C)C2</smiles><smiles>C[C@@H](Cc1cc2c(cc1O)OCO2)[C@H](C)Cc1cc2c(cc1O)OCO2</smiles>

240<smiles>[R]c1ccc(CC(C)C(C)Cc2cc(O)c(OC)c(OC)c2)cc1[R]</smiles>

241: $R_{1}=O H, R_{2}=H$ 242: $\mathrm{R}_{1}=\mathrm{OCH}_{3}, \mathrm{R}_{2}=\mathrm{OCH}_{3}$ 243: $\mathrm{R}_{1}=\mathrm{OH}, \mathrm{R}_{2}=\mathrm{OCH}_{3}$

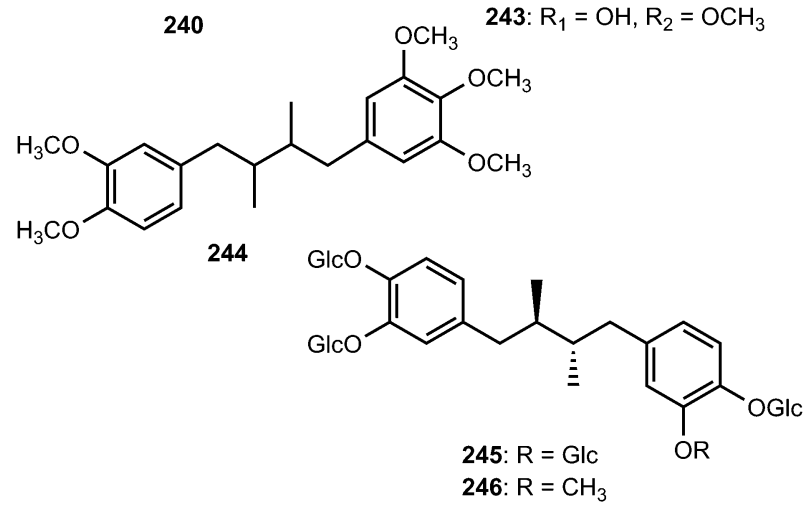<smiles>[Z16][Z16]#CC[C@H](C(=O)c1cc(OC)c(O)c(OC)c1)C(=O)[C@H](CO)C(=O)c1cc(OC)c(O)c(OC)c1</smiles><smiles>COc1cc(C[C@H]2[C@@H](OC)OC[C@H]2[C@H](O)c2ccc(O)c(OC)c2)ccc1O</smiles><smiles>COc1cc(C[C@H]2[C@@H](OC)OC[C@H]2[C@H](O)c2ccc(O)c(OC)c2)ccc1O</smiles>

249<smiles>COc1cc(C[C@H]2[C@@H](OC)OC[C@H]2[C@H](O)c2ccc(O)c(OC)c2)ccc1O</smiles>

251<smiles>O=C1OCC(Cc2ccc3c(c2)OCO3)=C1Cc1ccc2c(c1)OCO2</smiles>

252 (253-256). Their structures were determined by spectroscopic methods, HRCIMS, CD experiments, and chemical methods. Sanguinolignan A showed a moderate antileishmanial activity, but interestingly it had a very low cytotoxicity on macrophage and cancer or even normal cell lines. 4-O- $\beta$-D-Glucopyranosyl-7hydroxymatairesinol (257) and matairesinol 4-O- $\beta$-D- cellobioside (258) were isolated from Thellungiella salsuginea (Brassicaceae) ${ }^{\mathbf{1 0 0}}$ and Trachelospermum jasminoides (Lindl.) (Apocynaceae), ${ }^{\mathbf{1 0 1}}$ respectively. 
<smiles>O=C1OC[C@H]2[C@H](O)[C@H]1C(=O)C(=O)[C@H]2c1ccc2c(c1)OCO2</smiles>

253<smiles>COc1ccc([C@@H]2[C@@H]3COC(=O)[C@@H]3C(=O)[C@@H]2O)cc1OC</smiles>

255<smiles>COc1cc(C[C@H]2C(=O)OC[C@H]2Cc2ccc(OC)c(OC)c2)ccc1O</smiles>

257<smiles>O=C1OC[C@H]2[C@H](c3ccc4c(c3)OCO4)C(=O)[C@@]13C(=O)OC[C@H]23</smiles>

254<smiles>O=C1OC[C@@H]2C(=O)OC[C@H]1C2c1ccc2c(c1)OCO2</smiles><smiles>COc1cc(C[C@@H]2COC(=O)[C@@H]2Cc2ccc(OC(C)=O)c(OC)c2)ccc1O</smiles>

258
The previously unreported lignans $\left(8 S, 8^{\prime}-S\right)-4,3^{\prime}$-dihydroxy$3,4^{\prime}, 5^{\prime}$-trimethoxylignan-9',9-olide (259) and trans- $4^{\prime}, 8,8^{\prime}$-trihydroxy-3'-methoxy-3,4-methylenedioxylignan-9' ${ }^{\prime}$,9-olide

(260) were reported from the wood of Cunninghamia konishii (Taxodiaceae). ${ }^{\mathbf{1 0 2}}$ Eleven butyrolactone type lignans (261-271) were isolated from the fruits of Arctium lappa L. (Asteraceae). Compound $\mathbf{2 6 1}$ is a rare butyrolactone lignan with a 6-carboxyl2-pyrone moiety. Compounds 261, 266, 268, and 270 exhibited stronger anti-inflammatory effects than the positive control curcumin, particularly 261, which showed 75, 71, and $61 \%$ inhibition at 10,1 , and $0.1 \mu \mathrm{M}$, respectively. ${ }^{103}$

Secoisolariciresinol diglucosides (SDGs) (S,S)-SDG (277) (major isomer in flaxseed (Linum Usitatissimum) (Linaceae)) and $(R, R)$-SDG (278) (minor isomer in flaxseed) were synthesized from vanillin via secoisolariciresinol and a glucosyl donor through a concise route that involved chromatographic separation of diastereomeric diglucoside derivatives. ${ }^{\mathbf{1 0 4}}(S, S)$-SDG-1 is a potent antioxidant both in vitro and in vivo ${ }^{\mathbf{1 0 5 , 1 0 6}}$ and a powerful in vitro scavenging agent against hydroxyl free radicals. ${ }^{107}$ Vanillin was subjected to Stobbe condensation ${ }^{\mathbf{1 0 8}}$ with dimethyl succinate in the presence of lithium wire in refluxing methanol, and the resulting mixture of carboxylic acids was esterified with methanol under acidic conditions to furnish dimethyl ester $\mathbf{2 7 2}$ in $\mathbf{7 0 \%}$ overall yield (single isomer, unassigned olefin geometry). A second Stobbe condensation involving product with vanillin under the same lithium-<smiles>COc1cc(C[C@@H]2COC(=O)[C@H]2Cc2cc(O)c(OC)c(OC)c2)ccc1O</smiles><smiles>COc1cc(C[C@]2(O)C(=O)OC[C@@]2(O)Cc2ccc3c(c2)OCO3)ccc1O</smiles><smiles>COc1ccc(C[C@H]2COC(=O)[C@H]2Cc2cc(C(=O)O)oc(=O)c2)cc1OC</smiles><smiles>[R20]Oc1ccc(C[C@H]2C(=O)OC[C@H]2Cc2cc([R3])c(O[R2])c(OC)c2)cc1OC</smiles>

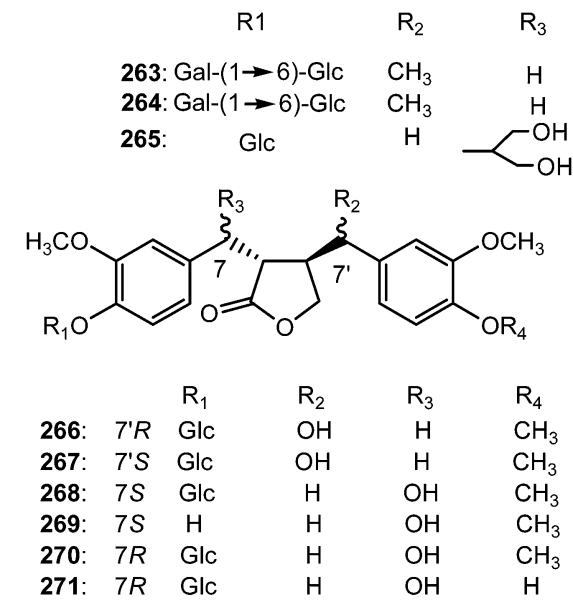

mediated conditions, followed by esterification with methanol under the same acidic conditions, led to diene 273 in $61 \%$ overall yield (single isomer, unassigned olefin geometry) (Scheme 8). The latter compound underwent diastereoselective hydrogenation ( $\mathrm{Pd} / \mathrm{C}, \mathrm{H}_{2}, 84 \%$ yield), phenolic benzylation ( $\mathrm{NaH}, \mathrm{BnBr}, 95 \%$ yield), and ester reduction $\left(\mathrm{LiAlH}_{4}, 93 \%\right.$ yield) to provide bis-benzyl secoisolariciresinol (274) whose relative stereochemistry was confirmed by X-ray crystallography. The glycosidation of $\mathbf{2 7 4}$ was achieved through the use of perbenzoyl-protected trichloroacetimidate under the influence of trimethylsilyl trifluoromethane sulfonate (TMSOTf), furnishing a diastereomeric mixture of inseparable bis- $\beta$-glucosides $(88 \%)$. Cleavage of the benzyl ethers by hydrogenolysis provided a mixture of diastereomeric bis-phenols (86\%), which proved 


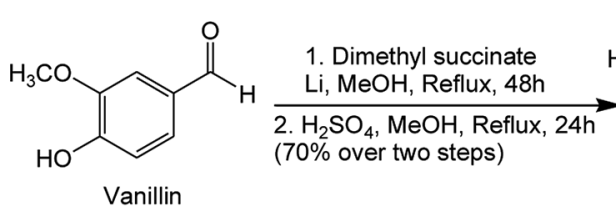<smiles>COC(=O)C/C(=C\c1ccc(O)c(OC)c1)C(=O)OC</smiles>
272

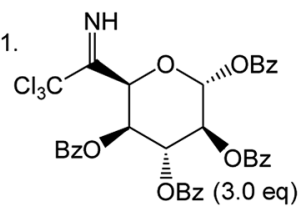

TMSOTf (.04 eq), $4 \AA$ sieves, $\mathrm{CH}_{2} \mathrm{Cl}_{2},-40$ to $25^{\circ} \mathrm{C}(88 \%)$

2. $\mathrm{Pd} / \mathrm{C}, \mathrm{MeOH}(86 \%)$

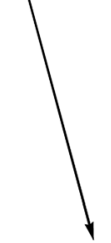

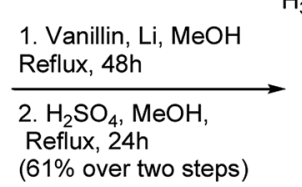

(61\% over two steps)<smiles>COC(=O)C(=Cc1ccc(O)c(OC)c1)C(=Cc1ccc(O)c(OC)c1)C(=O)OC</smiles>

273

1. $\mathrm{Pd} / \mathrm{C}, \mathrm{H}_{2}, \mathrm{MeOH}(84 \%)$<smiles>C=C(/C=C(\C)C[C@@H](C)CO)OC</smiles>

$\mathrm{BnO}$<smiles>C=C(O)/C=C\Cc1ccc(OC(C)C)c(OC)c1</smiles>
3. $\mathrm{LiAlH}_{4}, 0^{\circ} \mathrm{C}$ to $25^{\circ} \mathrm{C}(93 \%)$

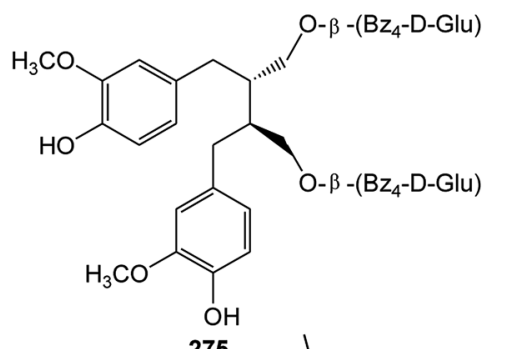

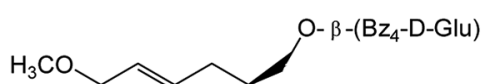

275<smiles></smiles><smiles>COc1cc(C[C@H](COC[C@H](O)[C@H](O)CO)[C@H](CO[C@H]2O[C@H](CO)[C@@H](O)[C@H](O)[C@H]2O)Cc2ccc(O)c(OC)c2)ccc1O</smiles>

$(S, S)-S D G(277)$<smiles></smiles>

276<smiles>COc1cc(C[C@H](CO[C@H]2O[C@H](CO)[C@@H](O)[C@H](O)[C@H]2O)[C@H](CO[C@H]2O[C@H](CO)[C@@H](O)[C@H](O)[C@H]2O)Cc2ccc(O)c(OC)c2)ccc1O</smiles>

$(R, R)$-SDG (278)

Scheme 8 Synthesis of secoisolariciresinol diglucosides (S,S)-SDG (258) and (R,R)-SDG (259).

separable by preparative thin layer chromatography (multiple elusions) to afford pure $\mathbf{2 7 5}$ and $\mathbf{2 7 6}$. Each perbenzoylated bisglucoside was treated with NaOMe in methanol to give the corresponding secoisolariciresinol diglucoside $(S, S)$-SDG (277) ( $88 \%$ yield) and $(R, R)$-SDG (278) (81\% yield) ${ }^{103}$ (Scheme 8$)$. The synthetic compounds $(S, S)$-SDG (277) and $(R, R)$-SDG (278) demonstrated powerful scavenging activities against hydroxyl (277: $\left.\mathrm{EC}_{50}=2.09 \pm 0.16 \mu \mathrm{M} ; 278: \mathrm{EC}_{50}=1.96 \pm 0.27 \mu \mathrm{M}\right)$, peroxyl (277: $\mathrm{EC}_{50}=2.20 \pm 0.10 \mu \mathrm{M} ; 278: \mathrm{EC}_{50}=3.03 \pm 0.04$ $\mu \mathrm{M})$ and DPPH $\left(277: \mathrm{EC}_{50}=157.54 \pm 21.30 \mu \mathrm{M} ; 278: \mathrm{EC}_{50}=\right.$ $123.63 \pm 8.67 \mu \mathrm{M})$ radicals. ${ }^{104}$

\subsection{Furofuran derivatives}

Epimagnolin B (279) is a furofuran lignan isolated from the flower buds of the medicinal plant Magnolia fargesii (Magnoliaceae). It was shown to inhibit the production of $\mathrm{NO}$ and $\mathrm{PGE}_{2}$ and the expression of respective enzyme iNOS and COX-2 through the suppression of $\mathrm{I}-\kappa \mathrm{B}-\alpha$ degradation and nuclear translocation of p65 subunit of NF-кB. ${ }^{109}$ Lactuberins A (280) and B (281) are constituents of Lactuca tuberosa, a wild edible plant species in Poland. Although furofuran lignans were previously reported from Lactuca indica and Lactuca sibirica, the 
two new natural products are the first reported ones from Lactuca species possessing axial/equatorial aryl groups in their 2,6 diaryl-3,7-dioxabi-cyclo[3.3.0] octane skeleton. ${ }^{110}$ Chushizisin I (282), a sesquilignan with partial pinoresinol- and dehydrodiconiferyl alcohol-type constituent units is among the lignans obtained from the fruits of Broussonetia papyrifera (Moraceae). ${ }^{111}$

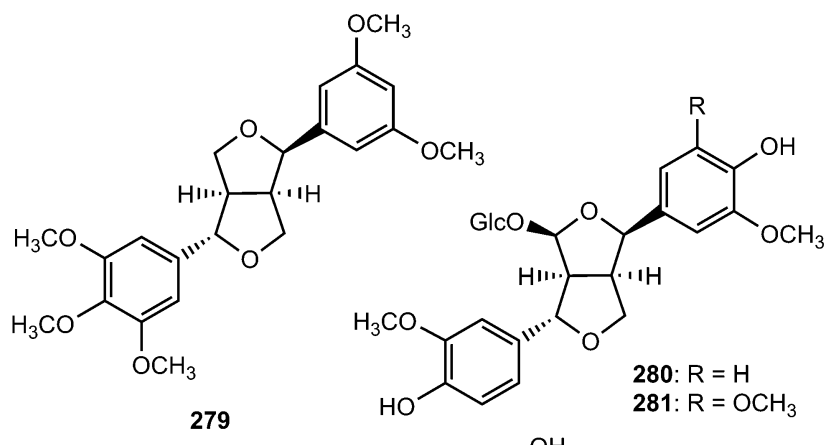<smiles>[R16]c1cc([C@H]2OC[C@H]3[C@H]2CO[C@H]3c2ccc(O)cc2)cc2c1O[C@H](c1ccc(O)cc1)[C@H]2CO</smiles>

Ten new furofuran lignans 283-292 were isolated from the ethanolic extract of the stem of Sinocalamus affinis (Poaceae). ${ }^{\mathbf{1 1 2}}$ The configurations of compounds 284-292 were elucidated by NMR and CD data analyses in combination with chemical transformations. The new sesamin type furofuran lignan, (-)-sesamin-2,2'-diol (293) was obtained from the aerial parts of Isodon japonicus (Lamiaceae), which are used for the treatment of gastrointestinal disorders, tumors, and inflammatory diseases. $^{\mathbf{1 1 3}}$ It showed relatively weaker inhibition of LPSinduced NO production in RAW264.7 cells than the positive control aminoguanidine. Acortatarinowin F (294a/294b) constitutes one of the pairs of lignan enantiomers isolated from the rhizomes of Acorus tatarinowii Schott (Araceae) through separation by chiral HPLC using a Daicel IC column. ${ }^{14}$ (-)-3,4,3', $4^{\prime}$-Tetrahydroxy-9, $7^{\prime}$ - $\beta$-epoxylignano-7 $\beta, 9^{\prime}$-lactone (295) is among the lignans isolated from the methanol extract from Morinda citrifolia. ${ }^{\mathbf{1 1 5}}$

Dipsalignan A-D (296-299), were reported from the roots of Dipsacus asper Wall (Caprifoliaceae). Compound 299 displayed weak activity against HIV-1 integrase. ${ }^{116}$ An investigation into the leaves of Vitex glabrata (Verbenaceae) led to the isolation khainaoside A (300), which showed potent inhibitory effects on estrogen-enhanced cell proliferation. The absolute configuration of the dioxabicyclooctyl ring was determined to be $7 R, 8 S, 7^{\prime} R, 8^{\prime} S$ from the negative Cotton effect at $227 \mathrm{~nm}$ in the CD spectrum. ${ }^{117}$

The furofuran lignan named colocasinol A (301) was reported from Colocasia antiquorum var. esculenta (Araceae), an edible vegetable in many tropical and subtropical regions of the world. ${ }^{118}$ Zanthoxylum podocarpum belongs to the genus Zanthoxylum of Rutaceae family, and its bark has been widely used

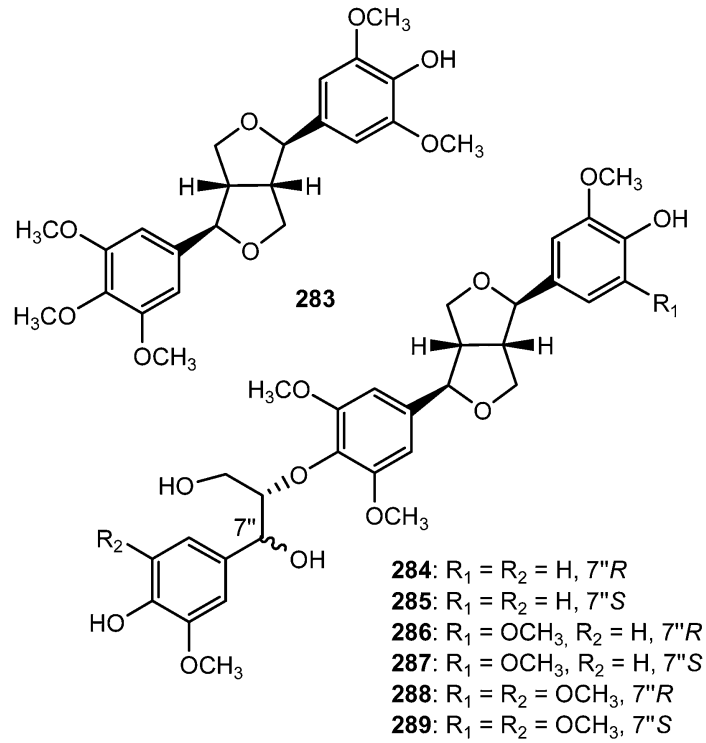

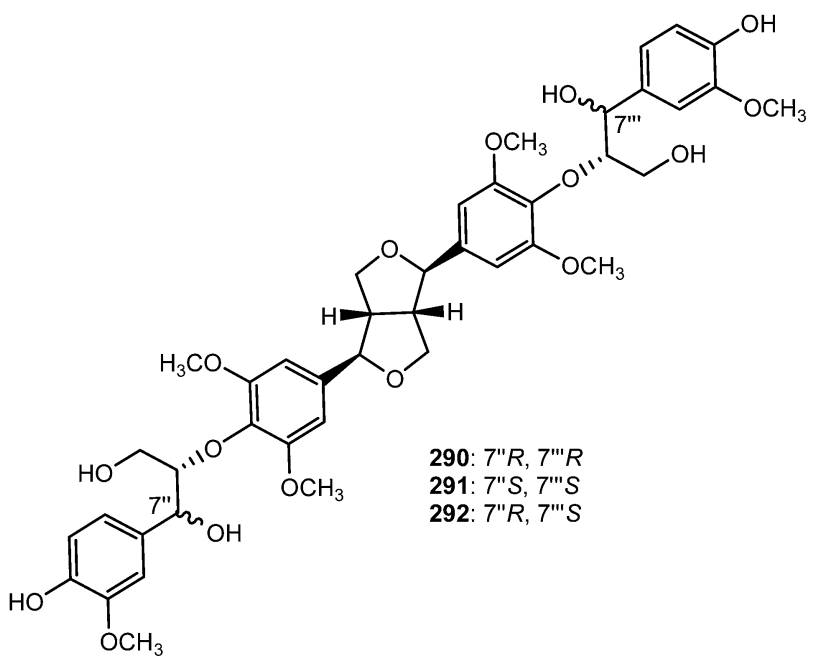<smiles>COc1cc(OC)cc([C@H]2OC[C@@H]3[C@@H](CO[C@H]3c3cc(OC)c(OC)c(OC)c3)[C@H]2c2ccc3c(c2O)OCO3)c1</smiles><smiles>COc1cc(OC)cc([C@H]2OC[C@@H]3[C@@H](CO[C@H]3c3cc(OC)c(OC)c(OC)c3)[C@H]2c2ccc(O)c(O)c2)c1</smiles> 
<smiles>[R]c1cc([C@H]2OC[C@]3(O)[C@@H](c4ccc(O)c(OC)c4)OC[C@]23O)cc(OC)c1O</smiles><smiles>COc1cc([C@@H]2OC[C@]3(O)[C@@H](c4cc(OC)c(O)c(OC)c4)OC[C@]23O)ccc1O</smiles>

as a folk medicine in PR China mainly for the treatment of rheumatoid arthritis and swelling. ${ }^{119}$ Zanthpodocarpins A (302) and B (303), isolated from its bark, are rare dilignans bearing an unusual $\alpha, \beta$-unsaturated ketone group from a natural resource. These compounds inhibited nitric oxide (NO) production in LPS stimulated RAW264.7 cells with $\mathrm{IC}_{50}$ of 5.3 and $12 \mu \mathrm{M}$, respectively. ${ }^{119,120}$ Two previously unreported dilignans bearing the same $\alpha, \beta$-unsaturated ketone group, bizanthplanispines A (304) and B (305), were recently isolated from the roots of Zanthoxylum planispinum Sieb. et Zucc (Rutaceae), ${ }^{\mathbf{1 2 1}}$ a deciduous shrub widely used as folk medicine for preventing toothache, stomachache and snake bites, treating colds and expelling round worms. The above compounds moderately reduced the proliferation of Hela cells with $\mathrm{IC}_{50}$ of 22 and $26 \mu \mathrm{g} \mathrm{mL} \mathrm{mL}^{-1}$, respectively.

\subsection{Furan derivatives}

The 7,7'-epoxylignans, ribesins A-D (306-309) and the tetrahydrofuran-type sesquilignans, ribesins E-G (310-312), were obtained from the leaves of Ribes nigrum (Grossulariaceae). Ribesins D and $\mathrm{G}$ demonstrated potent superoxide anion scavenging activities with $\mathrm{EC}_{50}$ of 1.2 and $1.1 \mu \mathrm{M}$, respectively. ${ }^{122} \mathrm{~A}$

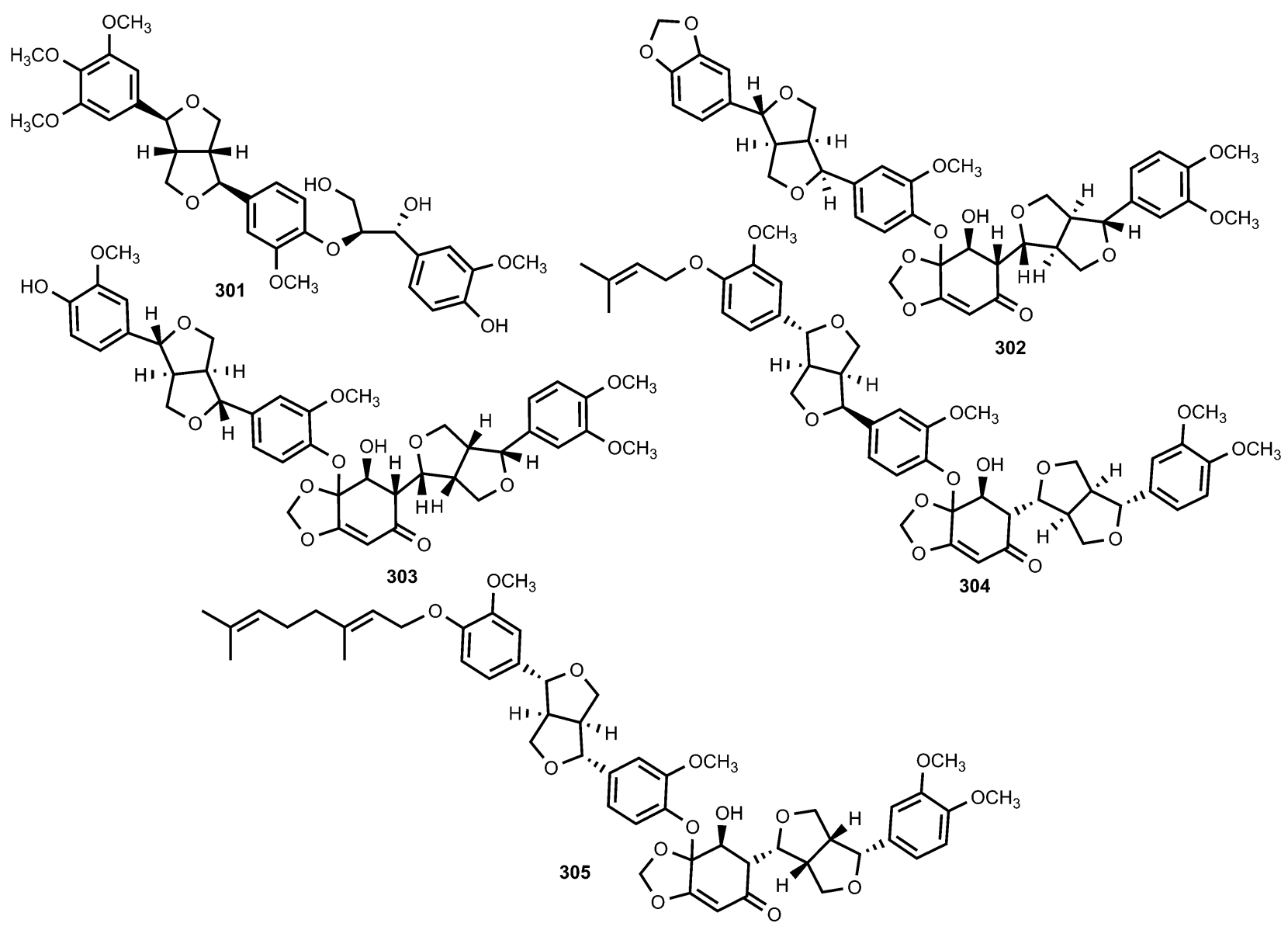


systematic bioactivity-guided isolation of the $70 \%$ aqueous acetone extract of Schisandra sphenanthera (Schisandraceae) roots led to the identification of eight new tetrahydrofuran lignans 313-320. Their absolute configuration were established on the basis of circular dichroism. Compound 320 showed the anti-oxidative haemolysis of human red blood cells (RBCs) activity with the $\mathrm{IC}_{50}$ of $35 \mu \mathrm{g} \mathrm{mL} \mathrm{m}^{-1}$, which is similar to that of vitamin $\mathrm{C}\left(33 \mu \mathrm{g} \mathrm{mL} \mathrm{m}^{-1}\right) .{ }^{93}$

The absolute configurations of tetrahydrofuranoid lignans 321-326 isolated from the fruit of Arctium lappa L. (Asteraceae) were confirmed using ROESY, the circular dichroic exciton chirality method, and $\mathrm{Rh}_{2}\left(\mathrm{OCOCF}_{3}\right)$ 4-induced $\mathrm{CD}$ spectrum analysis. They showed significantly stronger hepatoprotective activity against D-galactosamine-induced cytotoxicity in HL7702 hepatic cells than even the positive control (bicyclol) at a concentration of $1 \times 10^{-5}$ M. ${ }^{123}$ A bioassay-guided fractionation and chemical investigation of methanol extract of twigs of Lindera glauca (Sieb et Zucc.) Blume (Lauraceae) resulted in the isolation of three new lignan derivatives, named linderuca A (327), B (328), and C (329). The isolated compounds significantly inhibited NO production with $\mathrm{IC}_{50}$ of $12,9.4$, and $9.9 \mu \mathrm{M}$, respectively. ${ }^{\mathbf{1 2 4}}$

Saurufurins A-D (330-333) are secondary metabolites of Saururus chinensis. ${ }^{74}$ Furthermore, schinlignins A (334) and B (335) have also been isolated from $S$. chinensis. ${ }^{95}$ In addition to manglisin B, manglisins C-E (336-338) were isolated from the mature carpels of Manglietiastrum sinicum

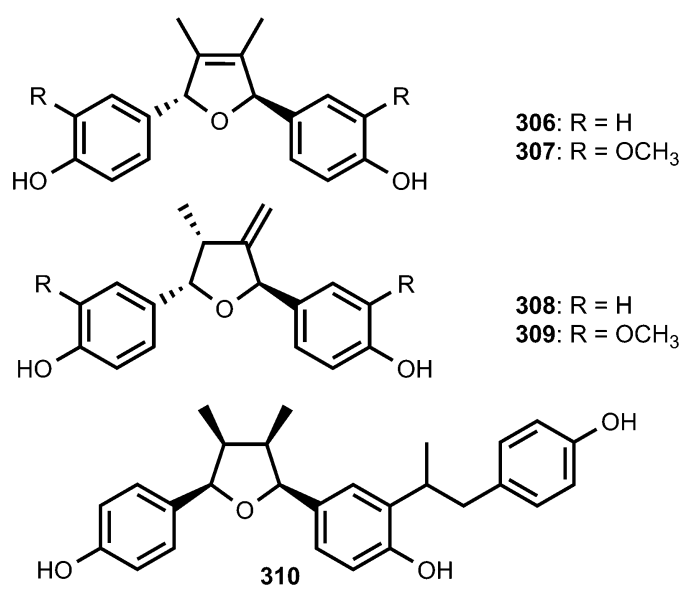<smiles>CC(Cc1ccc(O)cc1)c1cc([C@@H]2O[C@H](c3ccc(O)cc3)[C@H](C)[C@H]2C)ccc1O</smiles><smiles>CC(Cc1ccc(O)cc1)c1cc([C@@H]2O[C@H](c3ccc(O)c(O)c3)[C@@H](C)[C@H]2C)ccc1O</smiles>

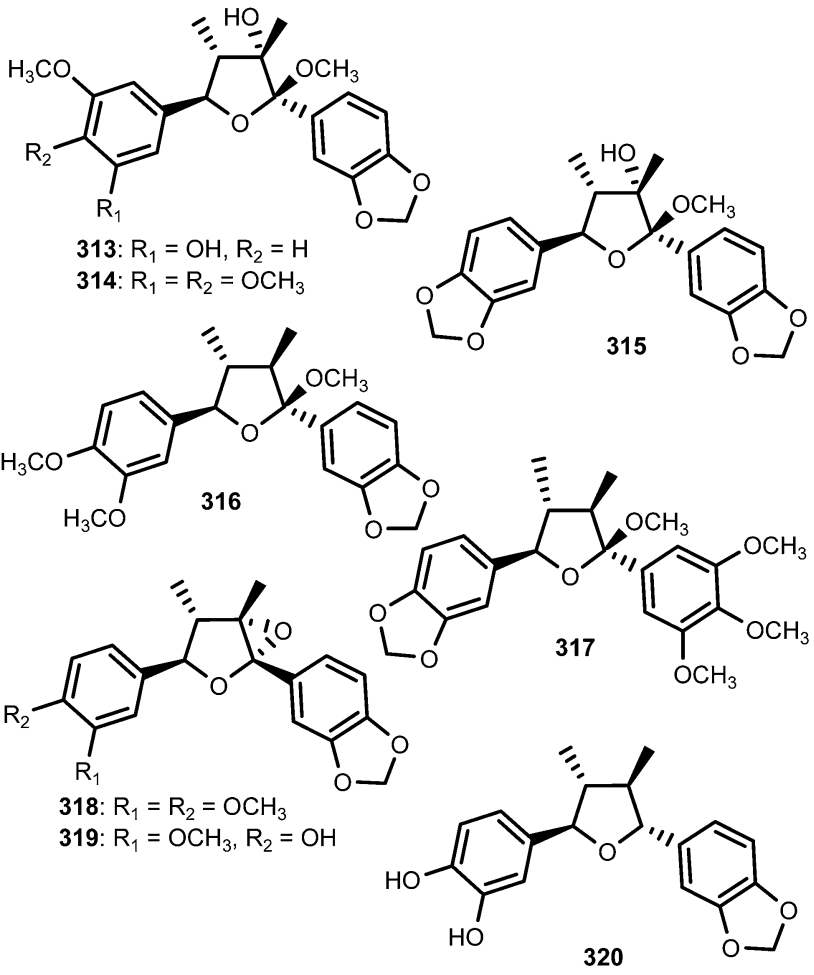

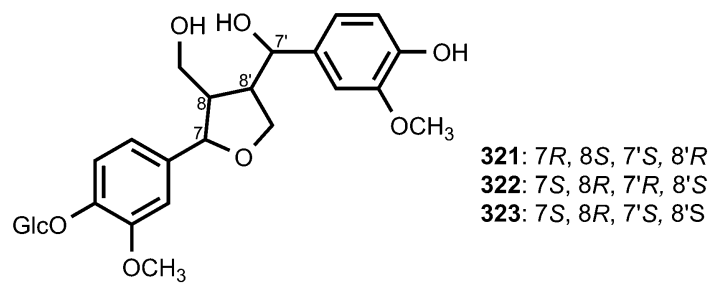

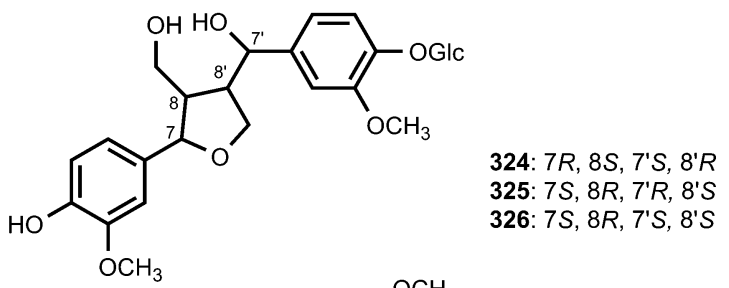

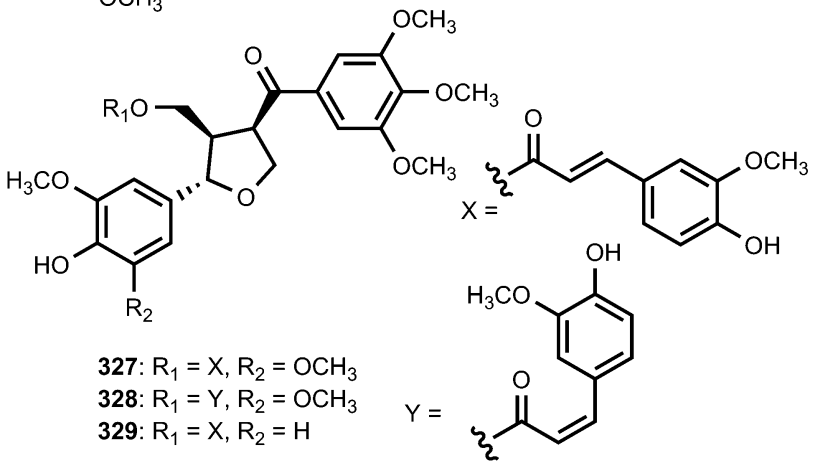


<smiles>[R]c1cc([C@H]2O[C@@H](c3cc(OC)c4c(c3)OCO4)[C@H](C)[C@@H]2C)cc(OC)c1OC</smiles><smiles>COc1cc([C@H]2O[C@@H](c3cc(O)c(OC)c(OC)c3)[C@H](C)[C@@H]2C)cc([C@@H]2O[C@@H](c3ccc(OC)c(OC)c3)[C@H](C)[C@H]2C)c1</smiles><smiles>[R2]c1cc([C@H]2O[C@@H](c3cc(O)c(OC)c(OC)c3)[C@H](C)[C@@H]2C)cc(OC)c1[R2]</smiles><smiles>COc1cc([C@H]2O[C@@H](c3ccc([C@@H]4OC[C@@H](Cc5cc(OC)c(O)c(OC)c5)[C@@H]4C)cc3OC)[C@H](C)[C@H]2C)ccc1O</smiles>

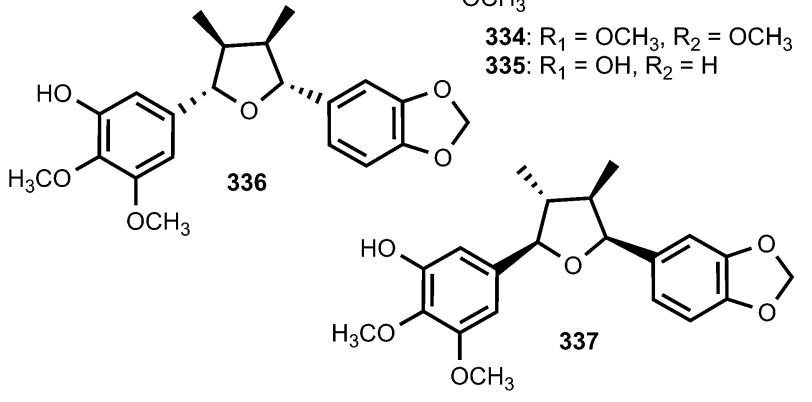<smiles>COc1cc([C@@H]2OC[C@H](C(=O)c3ccc(OC)c(OC)c3)[C@H]2CO)ccc1O</smiles>

(Magnoliaceae). ${ }^{49}$ Compounds 336 and 337 showed moderate antimicrobial activities (MIC 0.03-0.13 $\mu \mathrm{M}$ ) against Staphylococcus aureus, MRSA 82 $2^{\#}$, MRSA 92 $331^{\#}$. Additional previously unreported furan-type lignans include compounds 339 and 340, both isolated from the bark of Machilus robusta (Lauraceae), ${ }^{25}$ (+)-3-hydroxyveraguensin (341) from the leaves and the stem of Miliusa fragrans (Annonaceae), ${ }^{125}$ compound $\mathbf{3 4 2}$ from the fruits of Arctium lappa L. (Asteraceae), ${ }^{\mathbf{1 2 6}}$ and $\mathbf{3 4 3}$ from the methanol extract of Morinda citrifolia. ${ }^{\mathbf{1 1 5}}$

The investigation of methanol extract of the rhizomes of Acorus gramineus (Araceae) led to the isolation of two new tetrahydrofuran lignans, ligraminols A (344) and B (345) whose structures were determined by a combination of $1 \mathrm{D}$ and $2 \mathrm{D}$ NMR, HRMS, CD, and enzymatic hydrolysis. ${ }^{\mathbf{1 2 7}}$ These compounds were evaluated for their antiproliferative activities against three human cancer cell lines including A549, SK-OV-3, and SK-MEL-2 using the SRB bioassay. Ligraminol A was the most active against the SK-MEL-2 cell line with an $\mathrm{IC}_{50}$ value of 4.5 $\mu \mathrm{M}$. Chushizisins $\mathrm{G}$ (346) and $\mathrm{H}$ (347) are secondary metabolites reported from the fruits of Broussonetia papyrifera (Moraceae). ${ }^{\mathbf{1 1 1}}$ The new tetrahydrofuran lignan, (-)-diepiolivil (348), was isolated from a stem methanol-soluble extract of Cameraria latifolia (Apocynaceae); the absolute configuration of the 1,3-diol moiety was proposed from the CD spectrum induced with dimolybdenum tetraacetate in DMSO solution. ${ }^{\mathbf{2 8}}$ Beilschminol A (349) and the epoxylignan 350 were reported

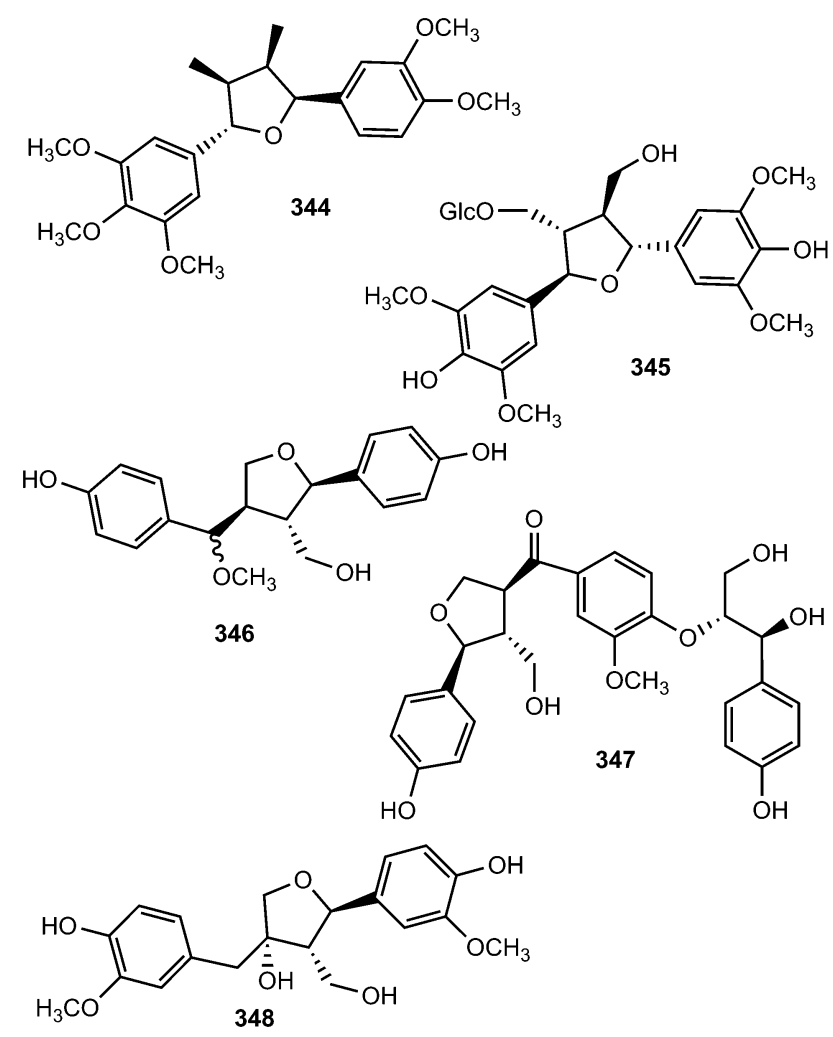


from Beilschmiedia tsangii (Lauraceae) ${ }^{\mathbf{1 2 9}}$ and Sinocalamus affinis ${ }^{112}$ respectively. The lignan epoxide (351) was isolated from the whole plant of Phillyrea angustifolia L. (Oleaceae) ${ }^{\mathbf{1 3 0}}$ while the sesquilignan (352) has been reported to be a constituent of fruits of Melia toosendan (Meliaceae) ${ }^{\mathbf{1 3 1}}$<smiles>COc1cc([C@H]2O[C@@H](c3cc(OC)c4c(c3)OCO4)[C@H](C)[C@@H]2C)cc(O)c1OC</smiles>

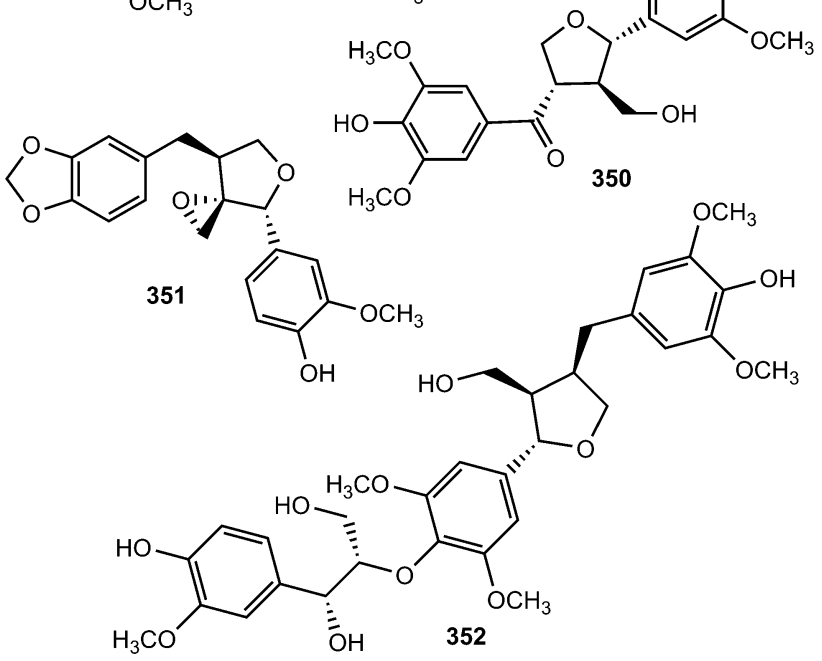

Activity-guided fractionation of Guaiacum officinale (Zygophyllaceae) heartwood extracts led to the isolation of four new spirocyclic lignans, named ramonanins A-D (353-356). ${ }^{132}$ These metabolites exhibited moderate in vitro cytotoxic activities against human breast cancer cell lines and induced cell death via apoptosis. More recently, ribesin $\mathrm{H}$ (357), bearing the same spirocyclic skeleton, was reported from the leaves of Ribes nigrum. ${ }^{122}$ The furano-2-oxaspiro[4,5]decane core of the ramonanins is unprecedented among known natural products; nonetheless, these compounds appear to be derived from a fairly straightforward oligomerization of four units of coniferyl alcohol-like precursors. Intriguingly, the ramonanins could be considered as dimers of two identical 1,3-di-(4hydroxy-3-methoxyphenyl)-substituted furans such as 358 (Scheme 9). ${ }^{132}$ The dimerization of 358, via a Diels-Alder-like mechanism, would directly lead to ramonanins A-D.

The bio-inspired total synthesis of the furan-type lignan tanegool (359) in four steps starting from ferulic acid was recently developed by Albertson and Lumb ${ }^{\mathbf{1 3 3}}$ based on the fact that lignan biosynthesis involves regio- and chemoselective oxidative coupling of propenyl phenols. They began their investigation by optimizing the $[2+2]$ photodimerization of $p$ nitro-ferulate ester $\mathbf{3 6 0}$ through irradiation of a suspension in hexane with a medium-pressure mercury lamp (Scheme 10). Reduction of the crude material with lithium aluminum hydride completed a 3-step synthesis of diarylcyclobutanediol 361, which proceeded with an overall yield of $74 \%$. The oxidative ring opening of $\mathbf{3 6 1}$ with phenyliodo diacetate led to natural product $( \pm)$-tanegool as a single diastereomer with a yield of up to $40 \%$.<smiles>C=C1[C@H](c2ccc(O)c(OC)c2)O[C@@H](c2ccc(O)c(OC)c2)[C@]12CCC1=C(C2)[C@@H](c2ccc(O)c(OC)c2)O[C@H]1c1ccc(O)c(OC)c1</smiles><smiles>C=C1[C@@H](c2ccc(O)c(OC)c2)O[C@]1(CC[C@@]12CCC3=C1[C@@H](c1ccc(O)c(OC)c1)O[C@@H]3C1=CC=C2OC(OC)=C1)c1ccc(O)c(OC)c1</smiles><smiles>C=C1[C@@H](c2ccc(O)c(OC)c2)O[C@@H](c2ccc(O)c(OC)c2)[C@]12CCC1=C(C2)[C@H](c2ccc(O)c(OC)c2)O[C@H]1c1ccc(O)c(OC)c1</smiles><smiles>C=C1[C@H](c2ccc(O)c(OC)c2)O[C@@H](c2ccc(O)c(OC)c2)[C@]12CCC1=C(C2)[C@@H](c2ccc(O)c(OC)c2)O[C@H]1c1ccc(O)c(OC)c1</smiles>

354<smiles>C=C1[C@H](c2ccc(O)cc2)O[C@@H](c2ccc(O)cc2)[C@]12CCC1=C(C2)[C@@H](c2ccc(O)cc2)O[C@H]1c1ccc(Br)cc1</smiles> 


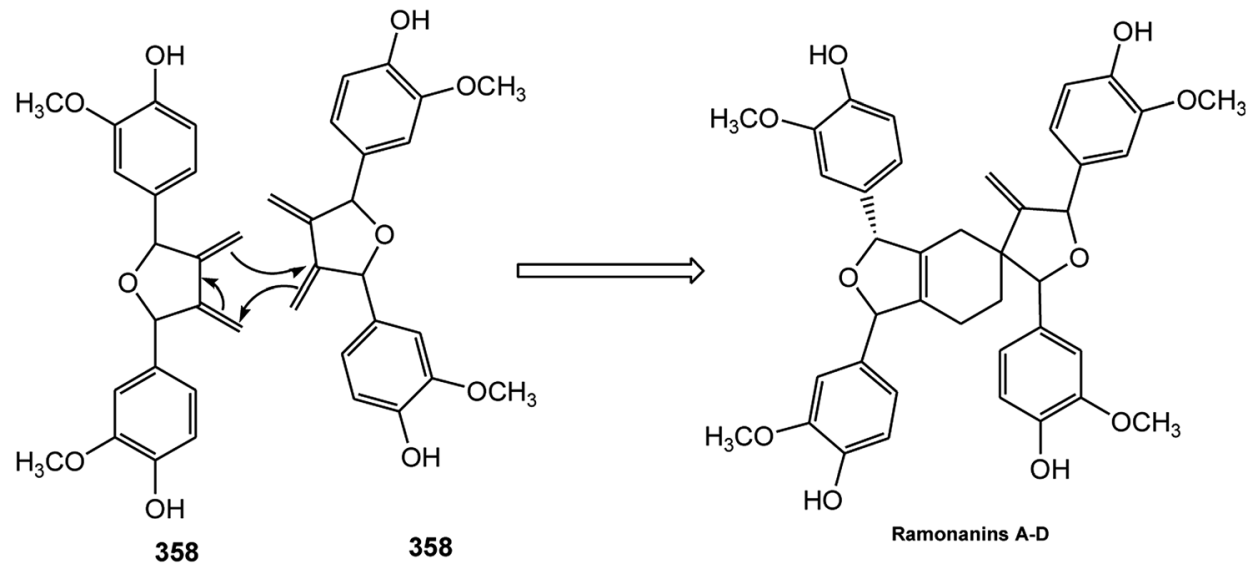

Scheme 9 Possible biogenesis of the ramonanins from putative diene precursor 358.<smiles>[R]OC=Cc1ccc(O)c(OC)c1</smiles>

1. EDC, $\square \begin{array}{r}\mathrm{R}=\mathrm{OH} \text {, ferulic acid } \\ \mathrm{DMAP}\end{array} \mathrm{R}=\mathrm{O}-\mathrm{C}_{6} \mathrm{H}_{4}-p-\mathrm{NO}_{2} 360$
2. Medium-pressure, Hg Lamp

3. $\mathrm{LiAlH}_{4}$

$\mathrm{HO}$

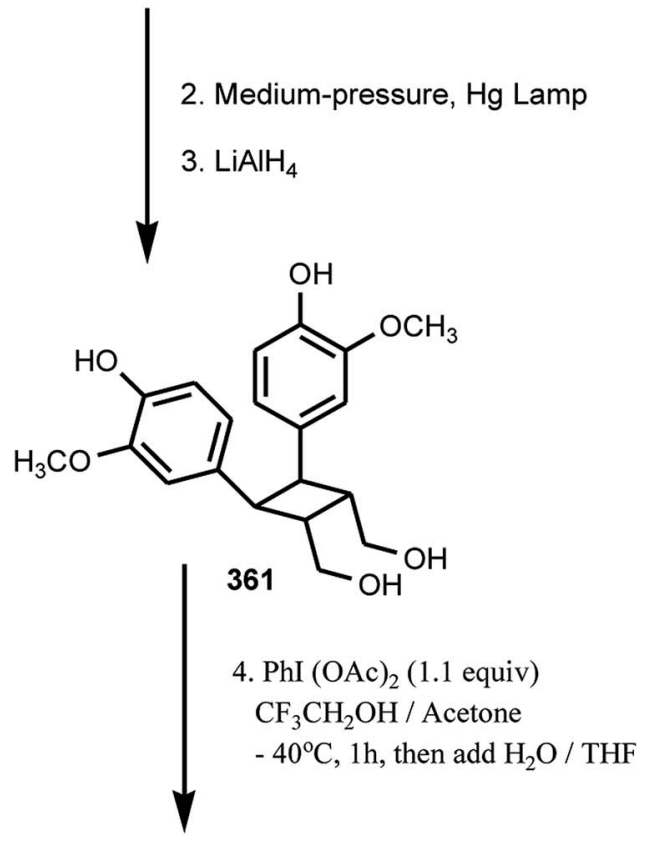

Scheme $10 \quad 4$-Steps synthesis of $( \pm)$-tanegool from ferulic acid.

\section{Neolignans}

\subsection{Benzofurans}

From the leaves of Miliusa mollis Pierre (Annonaceae), five new dihydrobenzofuran neolignans, namely 4'-O-methylmiliumollin, (362), 3'-methoxymiliumollin (363), miliumollin (364), 7-methoxymiliumollin (365) and miliumollinone (366), were isolated. Miliumollin, 3'-methoxymiliumollin and miliumollinone exhibited weak cytotoxicity against KB, MCF7 and NCI-H187 cells. ${ }^{134}$ Roots of Pittosporum glabratum Lindl. (Pittosporaceae) have been known for analgesic and antidotal properties in Chinese folk medicine. The structures and absolute stereochemistry of pittogosides A (367) and B (368) obtained from this plant were determined on the basis of spectroscopic analysis and chemical evidence, with a combination of circular dichroism. They were not active in a DPPH radical scavenging assay even at the concentration of $100 \mu \mathrm{M} .{ }^{\mathbf{1 3 5}}$ Methanol extract of the fruits of Vitex rotundifolia showed inhibitory effect on the nitric oxide (NO) production in RAW264.7 cells. The bioassayguided fractionation of the $\mathrm{CH}_{2} \mathrm{Cl}_{2}$-soluble fraction led to the isolation of two new neolignans 369 and 370 . Compound 369 was found to inhibit nitric oxide production with an $\mathrm{IC}_{50}$ of $21 \mu \mathrm{M}^{136}$

Bioassay-guided fractionation of the ethanolic extract of the stem of Aristolochia fordiana (Aristolochiaceae) led to the isolation of six new dihydrobenzofuran neolignans (371-376). ${ }^{137}$ The structures were established by spectroscopic methods, and their absolute configurations determined by analyses of the specific rotation and electronic circular dichroism data.

Phytochemical investigation of the methanol extract of Akebia quinata (Lardizabalaceae) afforded the neolignan glycosides akequintosides A (377) and B (378). The latter showed moderate inhibitory activity against IL-6 production in TNF- $\alpha$ stimulated MG-63 cells. $^{138}$ Meliasendanins B-D (379-381), exhibiting moderate ABTS radical-scavenging activity, are metabolites of Melia toosendan (Meliaceae) fruits. ${ }^{139}$ Saccharumoside A (382) is one of the glycosides isolated from the bark of Acer saccharum 
<smiles>[R]CC=CCCCC(C)=O</smiles><smiles>COc1cc(C(=O)OCC2C(O)C(O)C(O)C(O)C(Oc3c(OC)cc([C@@H]4Oc5c(OC)cc(CCCO)cc5[C@@H]4CO)cc3OC)C2[18O])cc(OC)c1O</smiles><smiles>COc1cc(CCCO)cc2c(COC(C)(C)C)c(-c3ccc(Cl)cc3)oc12</smiles><smiles>COc1cc([C@@H]2Oc3c(OC)cc(/C=C/C(O)OC)cc3[C@@H]2CO)ccc1O</smiles><smiles>COc1cc([C@@H]2Oc3c(OC)cc(/C=C\C(OC)OC)cc3[C@@H]2C)ccc1O</smiles>

(Aceraceae). It showed no cytotoxicity against two human colon tumorigenic (HCT-116 and Caco-2) cell lines and a nontumorigenic (CCD-18Co) cell line. ${ }^{\mathbf{1 4 0}}$ Phytochemical investigation of seeds of Euryale ferox (Nymphaeaceae) led to the isolation of two new sesquilignans, named euryalins A (383) and $\mathrm{B}$ (384). ${ }^{\mathbf{1 4 1}}$ Euryalin B exhibited strong effect against DPPH assay with $\mathrm{SC}_{50}$ values of $6.8 \mu \mathrm{M}$, comparable to that of the positive control (gallic acid or ascorbic acid). Strikingly, even though the structures of euryalins A and B are similar, except that compound A contains an additional methoxy group, their antioxidant activities are very different. These data suggested that the presence of OMe-5' might decrease the inhibitory activity.

The new acyclic phenylpropane lignanamide, named cisgrossamide K (385), was isolated from Colocasia antiquorum var. esculenta, (Araceae). This compound exerted moderate antimelanogenic activity on the cells without having high cell toxicity $\left(\mathrm{IC}_{50}=54 \mu \mathrm{M}\right.$ and $\left.\mathrm{LD}_{50}=164 \mu \mathrm{M}\right) .{ }^{118}$ Two neolignan glycosides 386 and 387 were isolated from the roots of Rhodiola crenulata $^{69}$ while compound 388 , characterized by a 1,2,3-<smiles>[R]c1cc(/C=C\C)cc2c1O[C@H](c1ccc3c(c1)OCO3)[C@H]2C</smiles>

374<smiles>C/C=C/c1cc(OC)c2c(c1)[C@H](C)[C@H](c1ccc(O)cc1)O2</smiles><smiles>C/C=C/c1ccc2c(c1)[C@@H](C)[C@H](c1ccc(OC)c(OC)c1)O2</smiles>

375<smiles>COc1cc([C@@H]2Oc3cc(CCCO)c(OC(Cl)(Cl)Cl)cc3[C@@H]2CO)ccc1O</smiles>

377<smiles>COC/C=C/c1cc2c(cc1OC([18OH])[18OH])[C@H](CO)[C@H](c1ccc(O)c(OC)c1)O2</smiles><smiles>COc1cc([C@H]2Oc3c(OC)cc(C(O)(O)[C@@H](O)CO)cc3[C@@H]2CO)ccc1O</smiles>

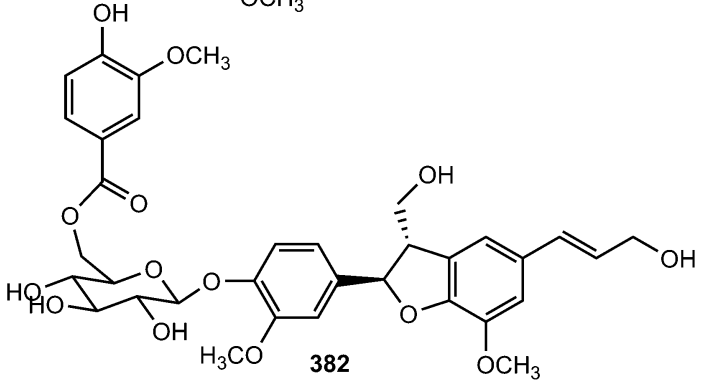<smiles>[R]c1cc([C@@H]2Oc3c(OC)cc(CCCO)cc3[C@@H]2CO)cc(OC)c1OC(CO)Cc1ccc(O)c(OC)c1</smiles> 
propantriol moiety, was obtained from the root bark of Illicium henryi (Illiciaceae). ${ }^{142}$ The fruits of Broussonetia papyrifera yielded chushizisins E (389) and F (390), which exhibited antioxidant activities against $\mathrm{H}_{2} \mathrm{O}_{2}$-induced impairment in PC12 cells with concentrations ranging from 0.16 to $100 \mu \mathrm{M}^{111}$<smiles>COc1cc([C@@H]2Oc3c(OC)cc(/C=C/C(=O)NCCc4ccc(O)cc4)cc3[C@H]2CO)ccc1O</smiles>

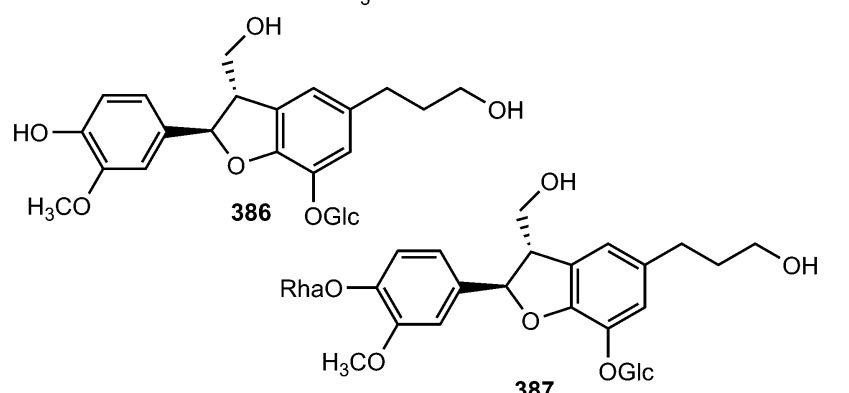<smiles>COc1cc([C@H]2[C@H](CO)c3cc(CCCO)cc(O)c3O[C@H]2c2cc(OC)c3c(c2)[C@H](CO)[C@@H](c2ccc(O)cc2)O3)ccc1OC(CO)CO</smiles>

Radulignan (391), a neolignan glycoside was obtained from polar extract of the roots of Lantana radula (Verbenaceae) growing in Brazil. ${ }^{143}$ The strong positive Cotton effect at $290 \mathrm{~nm}$ on its CD spectrum was indicative of a $7 S, 8 R$ configuration. It was tested for cytotoxicity against several cell lines (HL-60, K562, U937, CEM, KG-1, Jurkat, U266, and NCI-H929) and did not inhibit cell viability at $10 \mu \mathrm{M}$. $(7 R, 8 S)$-Cedrusinin 4-O- $\alpha$-L-rhamnoside (392) and (7R,8S)-cedrusin 4-O-(3-Omethyl- $\alpha$-L-rhamnoside) (393) were isolated from the trunk of Abies holophylla ${ }^{98}$ while ( $\left.7 R, 8 S\right)-3,5^{\prime}$-dimethoxy-4',7-epoxy-8,3'neolignane-5,9,9'-triol (394) inhibiting NO production in lipopolysaccharide-activated RAW264.7 macrophages $\left(\mathrm{IC}_{50^{-}}\right.$ value of $36 \mu \mathrm{M})$ was reported from the aerial parts of Leontopodium leontopodioides. ${ }^{\mathbf{1 4 4}}$ Linderanoside C (395) was characterized from the trunk of Lindera glauca. ${ }^{72}$ It was evaluated for its cytotoxicity against four human cell lines using sulforhodamine $\mathrm{B}$ assays in vitro and was shown to exhibit selective cytotoxicity against $\mathrm{A} 498$ cells with $\mathrm{IC}_{50}$ value of $23 \mu \mathrm{M}$. Benzofuran-type neolignans 396 and 397 are among the lignans obtained from the fruit of Arctium lappa L. ${ }^{\mathbf{1 2 3}}$<smiles>COc1cc([C@@H]2Oc3c(OC)cc(C(O)C(O)COC4CCCCC4)cc3[C@@H]2CO)ccc1Cl</smiles>

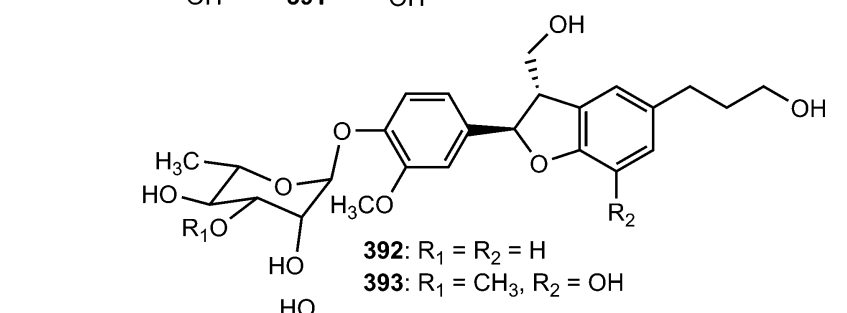<smiles>COc1cc(O)cc([C@@H]2Oc3c(OC)cc(CCCO)cc3[C@H]2CO)c1</smiles>

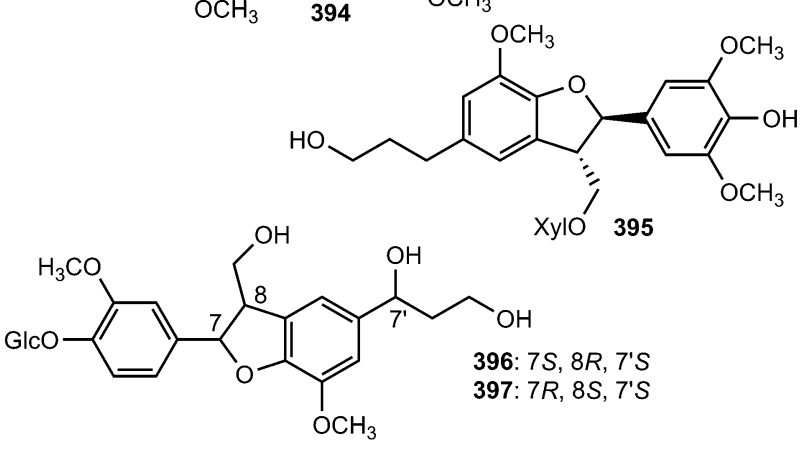

The absolute configuration of $\mathrm{C}-8^{\prime}$ in (-)-7'-dehydrosismbrifolin (398) and ( + )-7'-dehydrosismbrifolin (399) isolated from the fruits of Xanthium sibiricum (Asteraceae) was established using the $\mathrm{Mo}_{2}(\mathrm{OAc})_{4}$-induced circular dichroism (ICD). ${ }^{\mathbf{1 4 5}}$ Trogopterin A (400) was isolated from the feces of Trogopterus xanthipes Milne-Edwars (Petauristidae) which have been reported to promote blood circulation and resolve stasis. It exhibited moderate cytotoxic activities against HL-60 cells with $\mathrm{IC}_{50}$ of $46 \mu \mathrm{M} .{ }^{146}$ The lignan glycosides 401 and (+)-aquilignanoside A (402) were obtained from the fruits of Arctium lappa L. ${ }^{126}$ and Aquilaria sinensis (Thymelaeaceae), ${ }^{147}$ respectively. Compounds 403 and $\mathbf{4 0 4}$ are two neolignan glycoside enantiomers having extremely similar ${ }^{1} \mathrm{H}$ and ${ }^{13} \mathrm{C}$ NMR spectra isolated from the roots of Paeonia lactiflora (Ranunculaceae) after separation by chiral HPLC. ${ }^{148}$

The sesquineolignan prepicrasmalignan (405), was detected in the fruit wall of Cirsium eriophorum (L.) Scop (Asteraceae) using a combination of optimized acid treatments and complementary analytical methods (HPLC-MS, GC-MS, CD and NMR). ${ }^{149}$ Juniperigiside (406) was reported from the $\mathrm{CHCl}_{3}$ soluble fraction of the methanol extract of stem and leaves of the medicinal plant Juniperus rigida (Cupressaceae) ${ }^{\mathbf{1 5 0}}$ while compound $\mathbf{4 0 7}$ was obtained from Abies fabri (Pinaceae). ${ }^{151}$ The dihydrobenzofuranoid neolignan bearing a 1,3,4,5-tetrasubstituted benzene ring ococymosin (408) was characterized from the stem or bark of the Madagascan plant Ocotea cymosa (Lauraceae). ${ }^{152}$ It exhibited antiparasitic activity against the Dd2 strain of Plasmodium falciparum with an $\mathrm{IC}_{50}$ of $0.45 \mu \mathrm{M}$. 


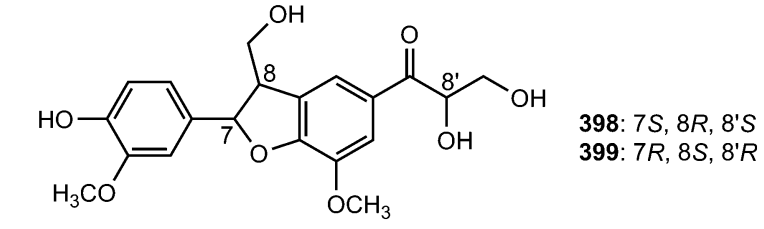<smiles>COC(=O)CCc1cc(O)c2c(c1)[C@@H](CO)[C@H](c1ccc(OC)c(O)c1)O2</smiles><smiles>COc1ccc([C@@H]2O[C@@H](c3ccc(Oc4ccc([C@H]5Oc6c(OC)cc(CCCO)cc6[C@@H]5C)cc4OC)cc3)c3c(OC)cc(CCCO)cc3[C@H]2C)cc1OC</smiles><smiles>CC[C@H](O)[C@H](C)c1cc([C@H]2Oc3c(OC)cc(/C=C/C=O)cc3[C@@H]2CO)cc(OC)c1O</smiles><smiles>COc1cc(CO)ccc1OCCOc1ccc([C@@H]2Oc3c(OC)cc(CCCO)cc3[C@@H]2CO)cc1OC</smiles><smiles>[R6]OC/C=C/c1cc(OC)c2c(c1)[C@@H](CO)[C@H](c1cc([R2])c([R7])c(OC)c1)O2</smiles>

409: $\mathrm{R}_{1}=\mathrm{R}_{2}=\mathrm{OCH}_{3}, \mathrm{R}_{3}=\mathrm{H} ; 7 \mathrm{R}, 8 \mathrm{~S}$ 410: $\mathrm{R}_{1}=\mathrm{OH}, \mathrm{R}_{2}=\mathrm{H}, \mathrm{R}_{3}=\mathrm{Et} ; 7 \mathrm{~S}, 8 \mathrm{R}$
Compounds 409 and 410 are constituents of the stem of Sinocalamus affinis (Poaceae). ${ }^{\mathbf{1 1 2}}$

The absolute configuration of the neolignan glycoside 411, isolated from the stem of Eurya japonica, was solved by ECD analysis which showed a positive Cotton effect at $232 \mathrm{~nm}$ and a negative effect at $217 \mathrm{~nm}$, indicating a $7 S, 8 R$ configuration. ${ }^{24}$ The sesquineolignan 412, possessing two dihydrobenzofuran moieties in its structure, is one of the secondary metabolites described from the fruits of Melia toosendan (Meliaceae). ${ }^{131}$ In traditional Chinese medicine, the hawthorn fruits of Crataegus pinnatifida (Rosaceae) are primarily used to improve circulation, remove blood stasis and treat indigestion, hyperlipidemia and hypertension. Seven new dihydrobenzofuran neolignans, pinnatifidanin CI-VII (413-419) exhibiting moderate cytotoxic and antioxidant activities were isolated from the seeds of this plant. ${ }^{153}$ Callislignan A (420) was reported from the leaves of Callistemon lanceolatus (Myrtaceae). It showed moderate antibacterial activity against $S$. aureus ATCC25923 and MRSA SK1. ${ }^{154}$

Monardic acids A (421), B (422) and C (423) were isolated from Monarda fistulosa L. (Lamiaceae) while lithospermic acid C (424) was reported from the roots of Lithospermum erythrorhizon (Boraginaceae). ${ }^{155}$ The absolute configuration of 421 was<smiles>[R4]C(CO)C(=O)c1cc(OC)c2c(c1)C(CO)C(c1cc(O)cc(OC)c1)O2</smiles>

413: $\mathrm{R}=\mathrm{H} ; 7 \mathrm{~S}, 8 \mathrm{R}$ 414: $\mathrm{R}=\mathrm{OH} ; 7 R, 8 \mathrm{~S} \quad \mathrm{HO}$<smiles>[R2]C(CO)C([R2])c1cc(OC)c2c(c1)C(CO)[C@H](c1ccc(O)c(OC)c1)O2</smiles>

415: $\mathrm{R}_{1}=\mathrm{OCH}_{3}, \mathrm{R}_{2}=\mathrm{OH}, 7 \mathrm{~S}, 8 R ; 7^{\prime}, 8^{\prime}$-threo 416: $\mathrm{R}_{1}=\mathrm{OCH}_{3}, \mathrm{R}_{2}=\mathrm{OH}, 7 R, 8 \mathrm{~S} ; 7^{\prime}, 8^{\prime}$-threo 417: $\mathrm{R}_{1}=\mathrm{OCH}_{2} \mathrm{CH}_{3}, \mathrm{R}_{2}=\mathrm{OH}, 7 \mathrm{~S}, 8 R ; 7^{\prime}, 8^{\prime}$-threo 418: $\mathrm{R}_{1}=\mathrm{OCH}_{2} \mathrm{CH}_{3}, \mathrm{R}_{2}=\mathrm{OH}, 7 R, 8 S ; 7^{\prime}, 8^{\prime}$-threo 419: $\mathrm{R}_{1}=\mathrm{OCH}_{2} \mathrm{CH}_{3}, \mathrm{R}_{2}=\mathrm{H}, 7 R, 8 \mathrm{~S}$<smiles>C/C=C/c1cc(O)c2c(c1)[C@H](C)[C@H](c1ccc(O)c(OC)c1)O2</smiles> 
confirmed by analysis of its hydrolysates, 7-epiblechnic acid and 2R-3-(3,4-dihydroxyphenyl)-2-hydroxypropanoic acid. The configuration in the dihydrobenzofuran moieties of 422-424 was extrapolated by using the phenylglycine methyl ester method and a Cotton effect at approximately 250-260 $\mathrm{nm}$ in their electronic circular dichroism spectra. ${ }^{155}$ The isolated compounds displayed moderate hyaluronidase inhibitory and histamine release inhibitory activities. Saposide B (425) is one of the lignan glycosides exhibiting moderate antioxidant activity

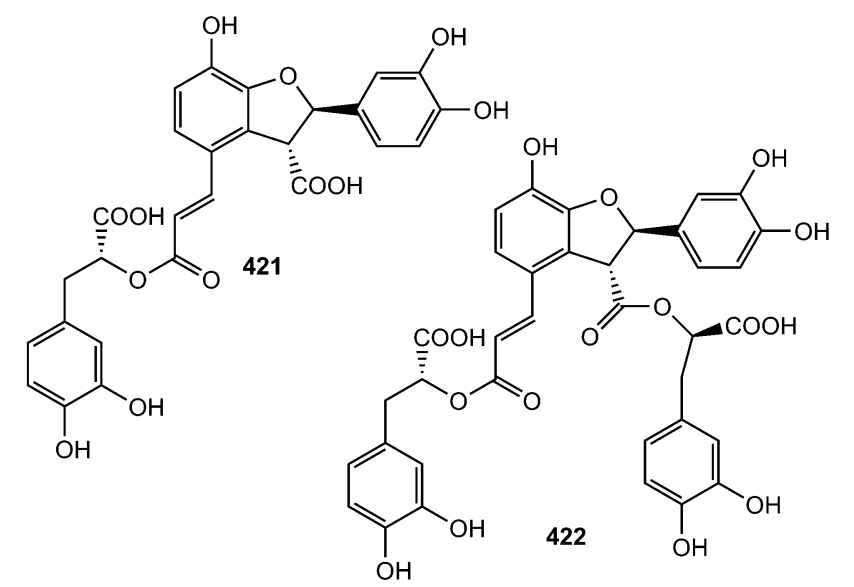<smiles>O=C(OC(Cc1ccc(O)c(O)c1)Cc1ccc(O)c(O)c1)O[C@H](Cc1ccc(O)c(O)c1)C(=O)O[C@@H](/C=C/c1ccc(O)c2c1[C@H](C(=O)O)[C@H](c1ccc(O)c(O)c1)O2)C(=O)O</smiles><smiles>COc1cc(/C=C/C(=O)OCCCc2cc(OC)c3c(c2)[C@@H](COC(=O)/C=C/c2ccc(O)cc2)[C@@H](c2ccc(O)c(OC)c2)O3)ccc1O</smiles>

on superoxide dismutase isolated from the maple sap of Acer saccharum $^{77}$ and Boehmenan $\mathrm{X}$ (426) was obtained from the bark of Durio carinatus. ${ }^{156}$

An efficient and practical asymmetric synthesis of the 2,3dihydrobenzo[b]furan neolignan acuminatin (427) was achieved by using trans-isoeugenol as the starting material by Lopez-Sanchez et al. ${ }^{157}$ The key step is an intramolecular $\mathrm{C}-\mathrm{H}$ insertion through a non-stabilized carbenoid, prepared by decomposition of a tosylhydrazone in the presence of an anthracenyl-derived cinchonidine quaternary ammonium salt as a chiral phase-transfer catalyst. First, the phenolic $\mathrm{OH}$ was protected with the ortho-directing group $N, N^{\prime}$-diethylcarbamate to form compound 428. Formilation in ortho position to give $\mathbf{4 2 9}$ was optimal when $s$-BuLi was used as a metallating agent and DMF as an electrophile. Aldehyde 429 was transformed into ketone $\mathbf{4 3 0}$ by a three-step process involving Grignard addition, Dess-Martin oxidation and hydrolysis of the carbamate group in alkaline media. Williamson etherification with 4-(iodomethyl)-1,2-dimethoxybenzene and treatment of $\mathbf{4 3 1}$ with tosylhydrazine yielded the desired tosylhydrazone $\mathbf{4 3 2}$ (Scheme 11). ${ }^{158}$ When the tosylhydrazone $\mathbf{4 3 2}$ is treated with potassium hexamethyldisilazane KHMDS in THF at $-80{ }^{\circ} \mathrm{C}$, cloudiness appears due to the formation of the potassium salt, which on heating, is unstable and decomposes in situ to form the diazo compound derivative (Scheme 12). ${ }^{157,158}$ In the presence of a metal catalyst, the diazo compound reacts with an activated $\mathrm{C}-\mathrm{H}$ bond through a carbenoid intermediate. The process inserts a 1,5-intramolecular carbon-hydrogen bond to form a five-member heterocycle through a well-established mechanism (Scheme 12). The reaction can be highly improved by the presence of phase-transfer catalysts, like quaternary ammonium salts, because they favor the transformation of the tosylhydrazone salt into the diazo compound and promote the solubility of rhodium catalysts. A series of rhodium salts were used but mixtures of cis/trans diastereoisomers were formed except for $\mathrm{Rh}_{2}\left(\mathrm{OCOCF}_{3}\right)_{4}$, which shows complete cis diastereoselectivity and 90\% yield. ${ }^{157}$

\subsection{Alkyl aryl ethers}

Hispidacine (433) is an 8,4'-oxyneolignan featuring incorporation of an unusual 2-hydroxyethylamine moiety at C-7 which induces moderate vasorelaxant activity in rat aorta isolated from the stem-bark and leaves of Malaysian Ficus hispida Linn (Moraceae). ${ }^{\mathbf{1 5 9}}$ Myrifralignans A-E (434-438) were reported from the seeds of Myristica fragrans Houtt (Myristicaceae). ${ }^{\mathbf{1 6 0}}$ Compounds 436-438 exhibited potent inhibitory activity against the production of nitric oxide (NO) in the RAW264.7 cell line stimulated by lipopolysaccharide. Repeated column chromatography of the $70 \%$ ethanol extract of the seeds of Crataegus pinnatifida (Rosaceae) resulted in the isolation of nine new 8-O$4^{\prime}$ neolignans, pinnatifidanin BI-IX (439-447). Pinnatifidanin BVIII displayed potent cytotoxic activity against the cancer cell line $\mathrm{U} 937$ with an $\mathrm{IC}_{50}$ of $2.7 \mu \mathrm{M}^{161}$ 
<smiles>C/C=C/c1ccc(OCC)c(OCC)c1</smiles><smiles>C/C=C/c1cc(C=O)c(C(=O)OCC)c(OC)c1</smiles><smiles>C/C=C/c1cc(OC)c(OCc2ccc(OC)c(OC)c2)c(C(C)=NCCN)c1</smiles>

432

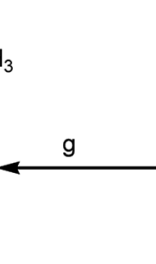<smiles>C/C=C/c1cc(OC)c(OCc2ccc(OC)c(OC)c2)c(C(C)=O)c1</smiles>

431

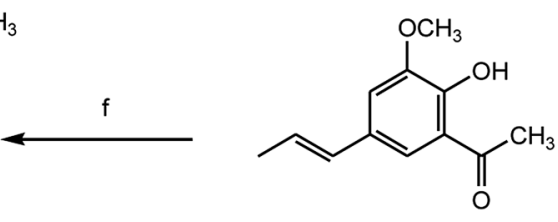

430

Scheme 11 Preparation of tosylhydrazone from trans-isoeugenol. Reagents and conditions: (a) $\mathrm{Et}_{2} \mathrm{NCOCl}$, pyridine, $100{ }^{\circ} \mathrm{C}, 90 \%$; (b) $\mathrm{s}$ - $\mathrm{Bu} \mathrm{Li}$, DMF, TMEDA, THF, $-90{ }^{\circ} \mathrm{C}, 85 \%$; (c) $\mathrm{Mg}, \mathrm{CH}_{3} \mathrm{l}, \mathrm{Et}_{2} \mathrm{O}, 0{ }^{\circ} \mathrm{C}, 93 \%$; (d) Dess-Martin oxidation, 95\%; (e) $\mathrm{NaOH}, \mathrm{EtOH}, 4,85 \%$; (f) $\mathrm{K}_{2} \mathrm{CO}_{3}, 4$-(iodomethyl)-1,2-dimethoxybenzene, $\mathrm{Me}_{2} \mathrm{CO}, \Delta, 85 \%$; (g) $\mathrm{TsNHNH}_{2}, \mathrm{MeOH}, \Delta, 92 \%$.

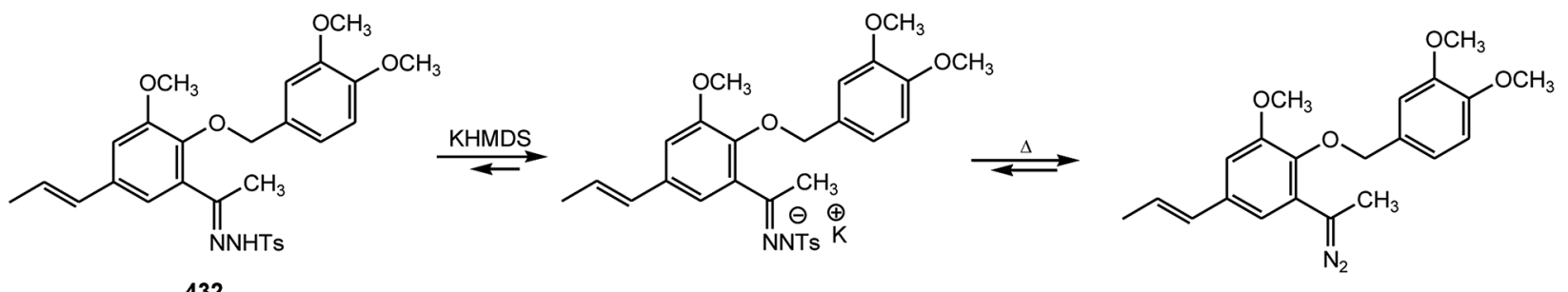

432<smiles>C/C=C/c1cc(OC)c2c(c1)C(C)C(c1ccc(OC)c(OC)c1)O2</smiles>

427

Scheme 12 Pathway for the $\mathrm{C}-\mathrm{H}$ insertion reaction through rhodium carbenoids by decomposition of tosylhydrazone 409 . Reagents and conditions: $\mathrm{KHMDS}$ was added at $-80^{\circ} \mathrm{C}$ to a THF solution of 409 ; then stirred for 30 min at $25^{\circ} \mathrm{C}$; next, $1 \%$ mol Rh(॥) catalyst and $n$-Bu $\mathrm{NBBr}_{4}$ were added and refluxed for $12 \mathrm{~h}$.

Fruits of Broussonetia papyrifera (Moraceae) have been used in traditional Chinese medicine for the treatment of age-related disorders. In order to find compounds that are responsible for the antioxidant effects of this plant, Mei et al. ${ }^{111}$ isolated chushizisins A-D (448-451). Chushizisins A, $\mathrm{B}$ and $\mathrm{D}$ showed DPPH radical-scavenging activities with $\mathrm{IC}_{50}$ of 237,156 , and $274 \mu \mathrm{M}$, respectively. Callislignan B (452) is a lignan reported from the leaves of Callistemon lanceolatus. It exhibited antibacterial activity against $S$. aureus ATCC25923 and MRSA SK1 with a MIC of $8 \mathrm{mg} \mathrm{mL}{ }^{-1}{ }^{154}$ Ligraminol E $4-O-\beta$-D-xyloside (453) is a secondary metabolite isolated from the trunk of Abies holophylla.$^{98}$ Phytochemical investigation of the methanol extracts prepared from leaves and stem of Miliusa fragrans led to the isolation of (-)-miliusfragranol A (454) and (-)-miliusfragranol B (455). ${ }^{125}$ Since no $\mathrm{CD}$ data of 8-O-4'-neolignans with established absolute configurations were available at that time, the absolute configurations of compounds $\mathbf{4 5 4}$ and 455 were not determined during this investigation. ${ }^{125}$

Syringa velutina Kom. (Oleaceae) has been widely cultivated in the northern parts of China and Korea for its medicinal applications to treat infectious fevers, counteract 
<smiles>C/C=C/c1cc(OC)c(O[C@H](C)[C@H](O)c2ccc3c(c2)OCO3)c(OC)c1</smiles><smiles>COc1ccc([C@@H](Oc2c(OC)cc(/C=C/C=O)cc2OC)[C@H](C)OC(C)(C)CO)cc1OC</smiles>

435<smiles>C=CCc1cc(OC)c(OC(C)[C@H](O)c2cc(OC)c(O)c(OC)c2)c(OC)c1</smiles><smiles>COc1cc([C@@H](C)[C@@H](C)Oc2c(OC)cc(/C=C/C=O)cc2OC)cc(OC)c1O</smiles>

437

inflammations, dampness and acute icteric hepatitis. The neolignan glycosides, (7S,8R)-guaiacylglycerol-8-O-4'-sinapyl ether $9^{\prime}-O-\beta$-D-glucopyranoside $(\mathbf{4 5 6})$ and $(7 S, 8 R)$-syringylglycerol-8-O-4'-sinapyl ether 9 '-O- $\beta$-D-glucopyranoside (457) were reported from this medicinal plant. ${ }^{162}$ Ligraminols C-E (458460) are three previously unreported neolignans from the rhizomes of Acorus gramineus (Araceae). Ligraminols C and D showed weak inhibitory activity against the proliferation of the human cancer A549 cell lines with $\mathrm{IC}_{50}$ of 9.5 and $8.3 \mu \mathrm{M}$, respectively. ${ }^{127}$

Acorus gramineus Soland (Araceae) is an aquatic perennial herbaceous plant widely distributed in Korea, Japan, and China. The plant's rhizomes have been used as a traditional medicine in China for the treatment of various disorders including cognitive problems, sedation, stomach ache, and oedema. ${ }^{163} \mathrm{~A}$ bioassay-guided fractionation and chemical investigation of the methanol extract of rhizomes of this plant resulted in the isolation and identification of thirteen phenolic derivatives including two new 8-O-4'-neolignans, surinamensinols A (461) and B (462). The newly isolated compounds showed antiproliferative activities against A549, SKOV-3, SK-MEL-2, and HCT-15 cell lines with $\mathrm{IC}_{50}$ values in the range of 4.2 to $26 \mu \mathrm{M} .{ }^{164}$ The neolignans threo-

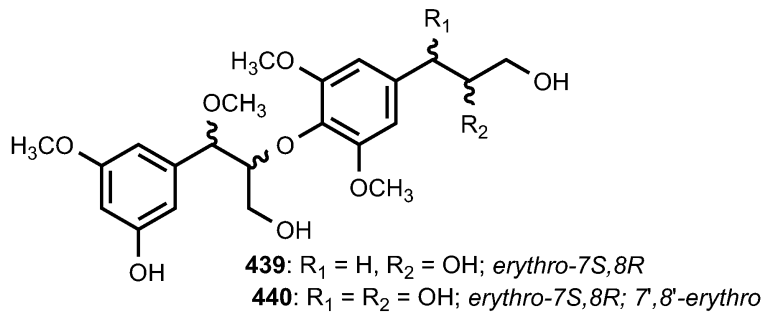<smiles>COc1cc(O)cc([C@@H](OC)[C@H](CO)Oc2c(OC)cc([C@@H](O)CCO)cc2OC)c1</smiles><smiles>COc1cc([C@@H](OC)[C@H](CO)Oc2ccc(CCCO)cc2OC)ccc1O</smiles><smiles>COc1cc([C@@H](O)[C@H](CO)Oc2c(O)cc(CCCO)cc2OC)ccc1O</smiles><smiles>COc1cc([C@@H](OC)[C@H](CO)Oc2ccc(/C=C/C=O)cc2OC)ccc1O</smiles><smiles>COC/C=C/c1ccc(O[C@H](CO)[C@H](OC)c2ccc(O)c(OC)c2)c(OC)c1</smiles>

guaiacylethoxyglycerol- $\beta-O-4^{\prime}$-coniferyl aldehyde ether (463) and erythro-guaiacylethoxyglycerol- $\beta$ - $O-4^{\prime}$-coniferyl aldehyde ether (464) are secondary metabolites of Melia toosendan. ${ }^{131}$ Compound 464 exhibited moderate agonistic activity on MT1 with agonistic rate of $21 \%$ at about $1 \mathrm{mM} .{ }^{147} \mathrm{Jeong}$ et al. ${ }^{76}$ reported the isolation of neolignans $\mathbf{4 6 5}$ and $\mathbf{4 6 6}$ from the leaves and twigs of the medicinal plant Euonymus alatus. Their absolute configurations have not been fully determined because the amounts obtained were too small.

The structures of compounds 467-471 isolated from the roots of Rhodiola crenulata were elucidated by spectroscopic data and chemical evidence supporting that they are optical isomers of two 8-O-4' neolignan glycosides. ${ }^{69}$ Two neolignans 472 and 473 related to guaiacylglycerol- $\beta$-coniferyl ether with two isovaleroyloxy groups were identified from the roots of Nannoglottis carpesioides (Asteraceae). ${ }^{165}$ They showed moderate radical-scavenging activity with $\mathrm{IC}_{50}$ of 22 and $17 \mu \mathrm{M}$, respectively. Miliusamollin (474) was among the lignans isolated from the leaves of Miliusa mollis Pierre ${ }^{134}$ while compounds 475 and 476 were obtained from the fruit of Arctium lappa $\mathrm{L} .{ }^{123}$ The 8-O- $4^{\prime}$ neolignan (477) was reported from the ethanolic extract of the stem of Aristolochia fordiana. ${ }^{137}$ 
<smiles>COc1cc(/C=C/CO)ccc1OC(CO)C(O)c1ccc(O)cc1</smiles><smiles>COc1cc(CCCO)ccc1OC(CO)C(O)c1ccc(O)cc1</smiles><smiles>C/C=C/c1ccc(OC(C)C(O)c2ccc(O)c(OC)c2)c(O)c1</smiles><smiles>C/C=C/CO</smiles><smiles>C=CCc1ccc(OC(C)Cc2ccc(O)c(OC)c2)c(OC)c1</smiles>

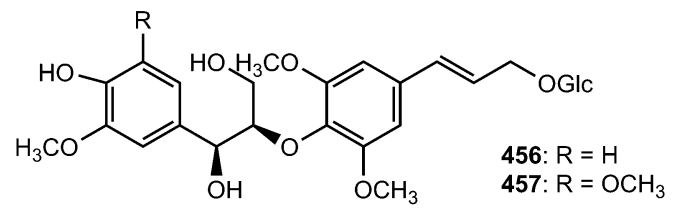<smiles>C/C=C\c1ccc(O[C@H](C)[C@H](OC(C)=O)c2ccc(OC)c(OC)c2)c(OC)c1</smiles><smiles>COc1ccc(C[C@@H](CO)Oc2ccc(CCCO)cc2OC)cc1OC</smiles><smiles>COc1cc(C[C@@H](CO)Oc2ccc(CCCO)cc2OC)ccc1O</smiles><smiles>COc1cc(CCCO)ccc1O[C@H](C)[C@@H](O)c1cc(OC)c(OC)c(OC)c1</smiles><smiles>CCO[C@H](c1ccc(O)c(OC)c1)[C@@H](CO)Oc1ccc(/C=C/C=O)cc1OC</smiles>

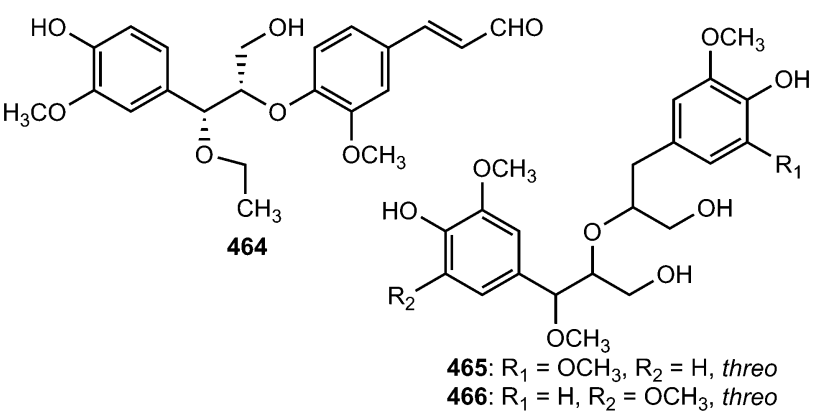

Systematic investigation of the rhizomes of Smilax trinervula (Smilacaceae) led to the isolation of compounds $\mathbf{4 7 8}$ and 479. The absolute configuration of $\mathbf{4 7 8}$ was deduced from CD data analysis while the stereochemistry of C-8 in $\mathbf{4 7 9}$ was not confirmed. These compounds showed no cytotoxic activity against five cancer cell lines (SH-SY5Y, SGC-7901 and HCT116). ${ }^{166}$ Symplocosneolignan 480 was characterized from the $n$ butanol soluble fraction of the methanol extract of Symplocos cochinchinensis var. philippinensis (Symplocaceae). ${ }^{167}$ Ethanol extract of the fruits of Arctium lappa L yielded $\mathbf{4 8 1}$ and $\mathbf{4 8 2}^{\mathbf{1 2 5}}$ while camellioside A (483) has been isolated from the leaves and branches of Camellia amplexicaulis (Theaceae). ${ }^{168}$

The pair of new 8-O-4'-type neolignan enantiomers $( \pm)$-acortatarinowin $\mathrm{D}(\mathbf{4 8 4 a} / \mathbf{4 8 4} \mathbf{b})$ was separated from the ethyl acetate soluble fraction of $95 \%$ methanol extract of Acorus tatarinowii Schott by chiral HPLC using a Daicel IC column. ${ }^{114}$ Compound $\mathbf{4 8 5}$ was reported from the stem or bark of Ocotea cymosa ${ }^{152}$ Its configuration was tentatively assigned as $S$ based on its positive optical rotation, as for synthetic $(S)$-virolongin B, a closely related compound even though the magnitude of the rotations differed significantly. Compounds 486-489 are stereoisomers sharing a common planar structure isolated from the roots of Paeonia lactiflora by chiral HPLC. The latter was found to show the optimal $A \beta_{1-42}$ aggregation inhibition potency $(81 \%$ at $20 \mu \mathrm{M}){ }^{148}$

The new guaiacylglycerol-feruloyl derivatives 490 and 491 were obtained from the roots of Medicago truncatula (Fabaceae). The guaiacylglycerol-feruloyl moiety of these compounds is 
<smiles>COc1cc(C(O)C(CO)Oc2ccc(CCCO)cc2OC)ccc1O</smiles><smiles>[R2]c1cc(CCCO)ccc1OC(CO)C(O)c1ccc(OC2CCCCO2)c(OC)c1</smiles><smiles>COC(=O)CC(C)C</smiles>

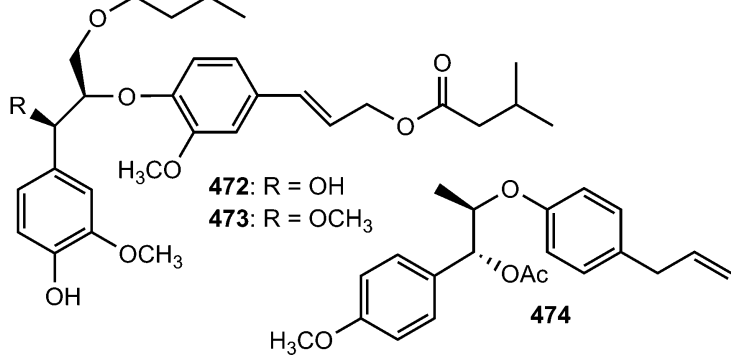<smiles>COc1ccc(C(=O)C(CO)Oc2ccc(C(O)CCO)cc2OC)cc1OC</smiles>

475: $8 R, 7^{\prime} S$<smiles>C#[C+]O[C@H](c1ccc2c(c1)OCO2)[C@@H](C)Oc1ccc(/C=C/C)cc1</smiles>

a neolignan derivative obtained from the oxidative dimerization of two coniferyl alcohol units. ${ }^{169}$ Investigation of chemical constituents from the bark of Durio carinatus (Bombacaceae) led to the isolation of threo-carolignan $\mathrm{X}$ (492), and erythro-carolignan X (493) while bark of Durio oxleyanus yielded threo-carolignan Y (494) and erythro-carolignan Y (495). ${ }^{156}$ The structures and stereochemistry of these compounds were solved by MS and NMR methods including NOESY and HSQC-HECADE and by interpretation of CD data. The dichloromethane extract from the leaves of Magnolia garrettii (Magnoliaceae) collected in Austria afforded two dimeric lignans, garrettilignans A (496) and $\mathrm{B}$ (497), each substituted with two additional $p$-allylphenolic moieties. ${ }^{170}$ Although the relative configuration of C-7 and C-8 of the propyl chain was not assigned, the occurrence of dineolignans bearing additional 4-allylphenyl moieties as described herein for garrettilignans $\mathrm{A}$ and $\mathrm{B}$ has not been reported previously.

\subsection{Benzodioxanes}

Because of the wide range of interesting biological activities exhibiting by this class of secondary metabolites, Pilkington and Barker ${ }^{171}$ have published recently a review on the synthesis and biology of 1,4-benzodioxane lignan natural products. The methanol extracts prepared from the leaves and stem of Miliusa fragrans were subjected to biological activity evaluation and<smiles>COc1cc(CCCO)cc(Cl)c1O[C@@H](O)[C@H](O)c1cc(OC)c(OC(F)(F)F)c(OC)c1</smiles><smiles>COc1cc(CC(CO)Oc2ccc(CCCO)cc2O)cc(OC)c1OC(F)(F)Cl</smiles><smiles>COc1cc(CCCO)cc(OC)c1O[C@H](C)[C@@H](O)c1cc(OC)c(OC(C)([O])[OH2+])c(OC)c1</smiles><smiles>COc1cc([C@@H](O)[C@H](CO)Oc2ccc(CCCO[GeH3])cc2OC)ccc1O</smiles><smiles>COc1cc(C(=O)[C@H](CO)Oc2ccc(CCCO)cc2OC)ccc1OC1CCCCC1</smiles><smiles>COCCCc1ccc(O[C@H](CO)[C@H](O)c2ccc(O)c(OC)c2)c(O)c1</smiles>

were found to possess inhibitory activity against both herpes simplex virus and cancer cells. Chemical examination of these extracts resulted in the isolation of five benzodioxane neolignans namely (+)-3-O-demethyleusiderin (498) C, (+)-4-Odemethyleusiderin C (499), (-)-miliusfragrin (500), (-)-4-Omethylmiliusfragrin (501) and (+)-eusiderin A (502). ${ }^{\mathbf{1 2 5}}$ Compound 499 showed recognizable anti-herpetic activity whereas 498, 499 and 500 exhibited appreciable cytotoxicity against some cancer cells. $(7 R, 8 R)-5-O$-Demethylbilagrewin (503) is one of the aromatic compounds isolated from the heartwood of the medicinal plant Santalum album (L.) (Santalaceae). It exhibited strong cytotoxic activity against HL-60 cells with $\mathrm{IC}_{50}$ of $1.5 \pm 0.02 \mu \mathrm{M} .{ }^{172}$ Other benzodioxanes include the glycoside $\mathbf{5 0 4}$ from the root bark of Illicium henryi, ${ }^{\mathbf{1 4 2}}$ eusiderin $\mathrm{N}$ (505) from the stem of Eurya japonica, ${ }^{24}$ and compound 506 from the methanol extract of Morinda citrifolia. ${ }^{\mathbf{1 1 5}}$

Bae and $\mathrm{Kim}^{173}$ undertook a convenient enzymatic transformation of caffeic acid with polyphenol oxidase originating from pear which afforded two 1,4-benzodioxane-type neolignans caffeicinic acid (507), and isocaffeicinic acid (508). Compound $\mathbf{5 0 7}$ significantly enhanced inhibitory activity against cyclooxygenase-2 (COX-2) when compared to parent caffeic acid with an $\mathrm{IC}_{50}$ of $7.5 \mu \mathrm{M}$. 
<smiles>C=CCc1cc(OC)c(O[C@H](CO)[C@H](O)c2ccc(OC)c(OC)c2)c(OC)c1</smiles>

485<smiles>COc1cc([C@H](O)[C@H](C)Oc2ccc(CCCO)cc2O)ccc1O</smiles><smiles>COc1cc([C@@H](O)[C@@H](C)Oc2ccc(CCCO)cc2O)ccc1O</smiles><smiles>COc1cc([C@@H](O)[C@@H](C)Oc2ccc(CCCO)cc2O)ccc1O</smiles>

\subsection{Biphenyl neolignans}

Streblus asper (Moraceae) is used by traditional healers as a remedy for hepatitis B virus in South China; notably, a plethora of biological activities have been reported with its extracts against dysentery, toothache, gingivitis, as well as having antibacterial and anti-inflammatory efficacies. The $n$ butanol soluble portion of a methanol extract of the stem bark of this plant was repeatedly purified by chromatography to afford 22 compounds including five neolignans: $\left(7^{\prime} S, 8^{\prime} S\right)$-transstreblusol A (509), $\left(7^{\prime} R, 8^{\prime} S\right)$-erythro-streblusol B (510), $\left(7^{\prime} S, 8^{\prime} S\right)$ threo-streblusol B (511), $8^{\prime} R$-streblusol C (512), and $\left(8 R, 8^{\prime} R\right)$ streblusol D (513). The stereochemistry at the chiral centers was determined using CD spectra, as well as analyses of coupling constants and optical rotation data. The new compounds exhibited anti-hepatitis $\mathrm{B}$ virus activity with $\mathrm{IC}_{50}$ ranging from 38 to $396 \mu \mathrm{M} .{ }^{174}$ Chen et al. ${ }^{175}$ reported $\left(7 R, 8 S, 7^{\prime} R, 8^{\prime} S\right)$-erythrostrebluslignanol $\mathrm{H}$ (514) from the same plant species while biseugenol A (515) was isolated from the bark of Litsea costalis (Lauraceae). ${ }^{\mathbf{1 7 6}}$

Strebluslignanol $\mathrm{F}(\mathbf{5 1 6})$ and $\left(7^{\prime} R, 8^{\prime} S, 7^{\prime \prime} R, 8^{\prime \prime} S\right)$-erythro strebluslignanol G (517) are two biphenyl neolignan dimers<smiles>[R]C(=O)/C=C/c1ccc(OC(CO)C(O)c2ccc(O)c(OC)c2)c(OC)c1</smiles>

490: $\mathrm{R}=$

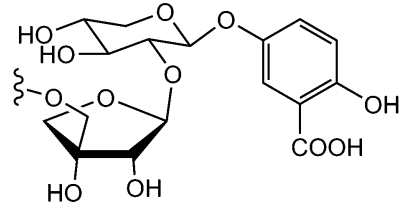

491: $\mathrm{R}=$<smiles>[Z]OCC(O)COC(OC(O)C(C(=O)O)C(O)C(O)C(=O)O)C(O)CO[Z]</smiles>

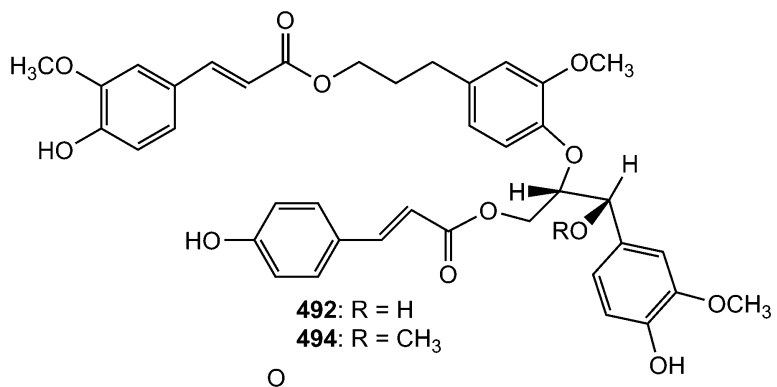<smiles>[R]O[C@H](c1ccc(O)c(OC)c1)[C@@H](COC(=O)/C=C/c1ccc(O)cc1)Oc1ccc(CCCOC(=O)/C=C/c2ccc(O)c(OC)c2)cc1OC</smiles>

obtained from the ethyl acetate soluble part of methanol extract from the roots of Streblus asper. ${ }^{177}$ The configuration was determined using CD spectra, as well as analyses of coupling constants and optical rotation data. They could be derived biogenetically via dehydration of $7^{\prime}, 8^{\prime}$-dihydroxyl and $4,4^{\prime}$-dihydroxyl groups of two strebluslignanols, respectively to form a dimer. Compound 517 exhibited significant antihepatitis $\mathrm{B}$ virus activity with an $\mathrm{IC}_{50}$ of $1.6 \mu \mathrm{M} .{ }^{177}$ Diallylcatechol (518), exhibiting moderate inhibitory effects on the aggregation of human platelet induced by collagen $\left(\mathrm{IC}_{50}\right.$ of $64 \mu \mathrm{M}$ ), is among the important secondary metabolites reported from Piper taiwanense (Piperaceae). ${ }^{\mathbf{1 7 8}}$ Neglignans C (519) and D (520), obtained from the acetone extract of the stems of Schisandra neglecta, are biphenyl neolignans characterized by the presence of 2-oxopropyl groups ${ }^{\mathbf{4 0}}$ considered as 7,8-secodibenzocyclooctadienes. Neglignan D exhibited cytotoxicity against the NB4 and SHSY5Y cancer cell lines with $\mathrm{IC}_{50}$ of 3 and $3.3 \mu \mathrm{M}$. 
<smiles>C=CCc1ccc(Oc2cc(CC=C)cc(O)c2OCC(O)C(O)c2cc(O)c(O)c(Oc3cc(CC=C)cc(Oc4ccc(CC=C)cc4)c3Oc3ccc(CC=C)cc3)c2)cc1</smiles>

496<smiles>C=CCc1ccc(Oc2cc(CC=C)cc(Oc3cc([C@H](O)CO)cc(O)c3OCC(O)Oc3cc(CC=C)cc(Oc4ccc(CC=C)cc4)c3O)c2O)cc1</smiles>

497

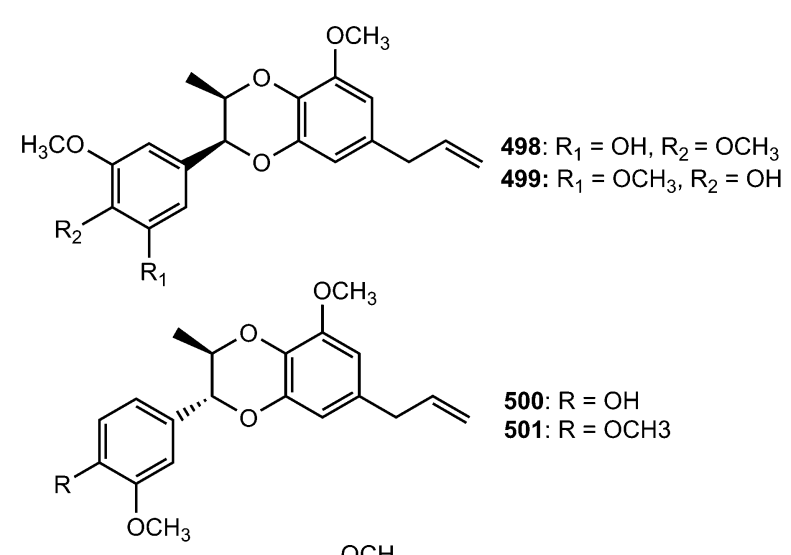<smiles>C=CCc1cc(OC)c2c(c1)O[C@H](c1cc(OC)c(OC)c(OC)c1)[C@H](C)O2</smiles>

\subsection{Other neolignans}

The macrophyllin-type bicyclo[3.2.1]octanoid neolignans ocophyllols A-C (521-523) were isolated from the leaves of Ocotea macrophylla Kunth (Lauraceae). They exhibited inhibition of platelet activating factor (PAF)-induced aggregation of rabbit platelets. ${ }^{179}$ Phytochemical exploration carried out on the leaves of Nectandra amazonum (Lauraceae) also afforded three new macrophyllin-type bicyclo[3.2.1]octanoid neolignans,<smiles>COc1cc([C@H]2Oc3c(O)cc(CCCO)cc3O[C@@H]2COC(C)(C)C)ccc1Oc1cc(CCCO)cc2c1O[C@H](c1cc(O)c(O)c(OC)c1)[C@H](C)O2</smiles><smiles>C=CCc1ccc(O)c(-c2cc([C@H]3O[C@@H]3C)ccc2O)c1</smiles><smiles>C=CCc1ccc(O)c(-c2cc([C@@H](OCC)[C@@H](C)O)ccc2O)c1</smiles><smiles>C=CCc1ccc(O)c(-c2cc([C@@H](C(C)=O)[C@@H](C)O)ccc2O)c1</smiles>
511<smiles>C=CCc1ccc(O)c(-c2cc(C(=O)[C@@H](C)O)ccc2O)c1</smiles><smiles>CS(=O)(=O)c1cc(C[C@@H](O)CO)ccc1-c1cc(C[C@@H](O)CO)ccc1O</smiles><smiles>C[C@@H](O)[C@H](O)c1ccc(O)c(-c2cc([C@H](O)C(C)(C)C)ccc2O)c1</smiles>

nectamazins A-C (524-526) whose absolute configuration was assigned on the basis of CD spectra supported by NOESY correlations. ${ }^{180}$ The new compounds showed inhibition of PAFinduced aggregation of rabbit platelets; nectamazin A (524) was found to be the most potent PAF-antagonist, even though the activity was slightly lower $\left(\mathrm{IC}_{50}\right.$ of $1.4 \mu \mathrm{M}$ ) than the positive control ginkgolide $\mathrm{B}$, a known PAF-antagonist obtained from 
<smiles>C=CCc1ccc(O)c(-c2ccc(C3O[C@H](C)[C@@H](C)O[C@H]3C)cc2-c2c(O)ccc(CC=C)c2-c2cc(CC=C)ccc2O)c1</smiles>

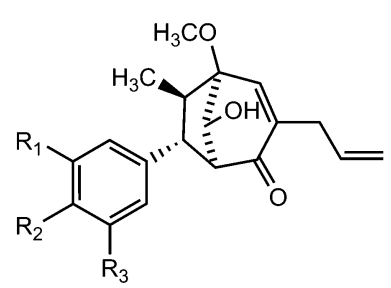

521: $\mathrm{R}_{1}, \mathrm{R}_{2}=\mathrm{OCH}_{2} \mathrm{O} ; \mathrm{R}_{3}=\mathrm{H}$ 522: $\mathrm{R}_{1}=\mathrm{R}_{2}=\mathrm{OCH}_{3} ; \mathrm{R}_{3}=\mathrm{H}$ 523: $\mathrm{R}_{1}=\mathrm{R}_{2}=\mathrm{R}_{3}=\mathrm{OCH}_{3}$

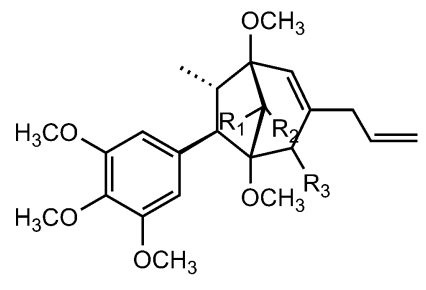

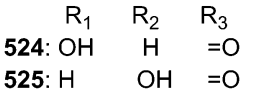
526: $\mathrm{OH} \quad \mathrm{H}$ exo $\mathrm{OH}$<smiles>[R]c1cc([Z]2[C@H](CC=C)CC3(OCO3)[C@H]2C)cc2c1OCO2</smiles>

527: $\mathrm{R}=\mathrm{H}$ 528: $\mathrm{R}=\mathrm{OH}$<smiles></smiles>

530<smiles>C=CC[C@]12C[C@]3(OCOC3=CC1=O)[C@@H](C)[C@H](c1cc(OC)c(OC)c(OC)c1)C2=O</smiles>

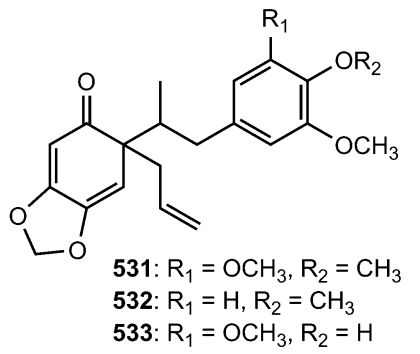

Ginkgo biloba. The bark of the Madagascan plant Ocotea cymosa afforded compounds 527-530 together with the 6'-oxo-8.1'lignans cymosalignans $\mathrm{A}-\mathrm{C}$ (531-533) and didymochlaenone $\mathrm{C}$ (534).$^{152}$ Compounds 527-530 belong to a rare group of bicyclo [3.2.1] octanoid neolignans possessing a 7.1'.8.3' coupling with unique features such as the deoxygenated C-2' between the bridge heads and the methylenedioxy group on the cyclohexenone ring. The relative and absolute configurations of 531533 were not assigned. ${ }^{142}$

Biseugenol B (535) and isostrebluslignanaldehyde (536) are constituents of Litsea costalis ${ }^{176}$ and Streblus asper, ${ }^{177}$ respectively. Bioassay-guided fractionation of roots of Piper taiwanense led to isolation of four previously unreported neolignans namely neotaiwanensol A (537), neotaiwanensol B (538), taiwandimerol A (539) and taiwandimerol B (540). ${ }^{178}$ Compounds 539 and 540 showed moderate inhibitory effects on the aggregation of human platelet induced by collagen with $\mathrm{IC}_{50}$ of 56 and $72 \mu \mathrm{M}$, respectively.

Prebalanophonin (541) is one of the main neolignans detected in Cirsium eriophorum using a combination of optimized acid treatments and complementary spectroscopic (HPLC-MS, GC-MS, CD and NMR) methods. ${ }^{149}$ A pair of rare C7C8-type neolignan enantiomers trivially named (+)-acortatarinowin E (542a) and (-)-acortatarinowin E (542b) was obtained from the rhizomes of Acorus tatarinowii Schott after separation using a chiral HPLC column. ${ }^{144}$ Trogopterins B (543) and C (544) are among the lignans obtained from the feces of Trogopterus xanthipes Milne-Edwars. ${ }^{146}$ They exhibited moderate cytotoxic activities against HL-60 cells with $\mathrm{IC}_{50}$ of 35 and $42 \mu \mathrm{M}$, respectively.<smiles>C=CCc1cc(OC)c(O[C@]23CC(CC=C)C(=O)C=C2OCO3)c(OC)c1</smiles><smiles>C=CCc1ccc(OC)c(Oc2cc(CC=C)ccc2OC)c1</smiles>

535<smiles>C=CCc1ccc(Oc2ccc(/C=C/C=O)cc2)c(/C=C/Cc2cc(O)c(O)cc2CC=C)c1</smiles><smiles>C=CCc1cc(O)c(O)cc1C(C=C)c1ccc(O)c(O)c1</smiles><smiles>[R]c1ccc(O)c(Oc2ccc(C(O)C(O)COC)cc2O)c1</smiles>

539: $\mathrm{R}=\mathrm{CH}_{2} \mathrm{CH}=\mathrm{CH}_{2}$ (threo) 540: $\mathrm{R}=\mathrm{CH}=\mathrm{CHCH}_{2} \mathrm{OCH}_{3}$ (threo) 
<smiles>COc1cc(/C=C/C=O)cc([C@@H](CO)[C@@H](O)c2cc(OC)c(OC)c(OC)c2)c1O</smiles><smiles>COC(=O)CCc1cc(O)cc([C@H](CO)Cc2cccc(O)c2)c1</smiles>

$542 b$<smiles>COC[C@H]1c2ccc(O)cc2C[C@H](CO)[C@H]1c1cccc(O)c1</smiles><smiles>[R]c1cc([C@@H](OC)[C@H](C/C=C/c2ccc(O)cc2)C(=O)OC)ccc1O</smiles>

Five new 8-9' linked neolignans, conchigeranals A-E (545549) were isolated from the whole plant of Alpinia conchigera (Zingiberaceae). ${ }^{\mathbf{1 8 1}}$ However, the relative stereostructures of 547-549 were not determined. Compounds 548 and 549 exhibited cytotoxicity against A549 cell lines with $\mathrm{IC}_{50}$ of 12 and $10 \mu \mathrm{g} \mathrm{mL}{ }^{-1}$, respectively. Two 2,4'-epoxy-8,5'-neolignans, penthorins A (550) and B (551), were isolated from an ethyl acetate soluble portion of a hepatoprotective water decoction of<smiles>C/C=C\c1cc2c(cc1O)Oc1c(ccc(O)c1OC)C(=O)[C@@H](C)c1cc(O)c(OC)c(c1)Oc1c-2ccc(O)c1OC</smiles>

Penthorum chinese (Saxifragaceae). Their structures and absolute configurations were elucidated by extensive spectroscopic analyses and electronic circular dichroism (ECD) calculations. Interestingly, this was the second report on occurrence of $2,4^{\prime}$ epoxy-8, $5^{\prime}$-neolignans in plants. The latter showed in vitro protective activities against acetaminophen-induced hepatocyte injury at $5 \mu \mathrm{M} .{ }^{182}$ Do Vale et al. ${ }^{183}$ reported the unusual caffeic acid derived bicyclic[2.2.2] octane neolignan, rufescenolide (552) from the stem of Cordia rufescens (Boraginaceae).

The neolignan glucosides saccharnans A (553) and B (554) possessing a rare skeleton were isolated from the desugared sugar cane (Saccharum officinarum) extract. ${ }^{\mathbf{1 8 4}}$ Phytochemical investigation of the chloroform and ethyl acetate-soluble extracts of the leaves of Vitex quinata (Verbenaceae) afforded a new $\delta$-truxinate derivative, dimethyl $3,4,3^{\prime}, 4^{\prime}$-tetrahydroxy- $\delta$ truxinate (555), which did not show any efficacy against a panel of three selected human cancer cells. ${ }^{185}$ Compound 556, also believed to be derived from dimerization of two phenylpropanoyl esters of catechol glycoside units, was obtained from the leaves of Dodecadenia grandiflora. ${ }^{79}$<smiles>[R20]Oc1ccc(/C=C2/C(=O)O[C@H](CO)[C@H]2c2cc(OC)c([R20])c(OC)c2)cc1</smiles>

553: $R_{1}=H, R_{2}=G l c$ 554: $R_{1}=G l c, R_{2}=H$<smiles>CCCCC(C)(C)C</smiles>

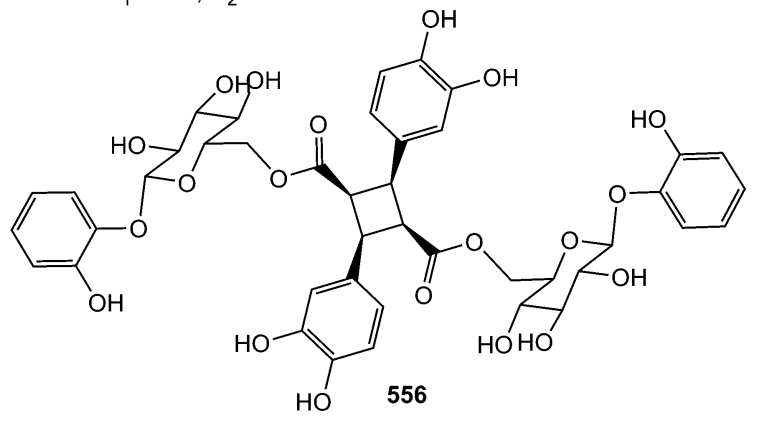

\section{Miscellaneous}

Tsangin C (557) is a secolignan reported from the roots of Beilschmiedia tsangii. ${ }^{129}$ Closely related compounds 558 and 559 were also characterized from the mature carpels of Manglietiastrum sinicum. ${ }^{49}$ They were derived from tetrahydrofuran lignans via oxidative cleavage of the C7-C8 bond. Secondary metabolites 560 and 561 are norbenzodioxane neolignans resulting from a phytochemical study of Morinda citrifolia..$^{\mathbf{1 1 5}}$ The dihydrobenzofuran type dinorneolignans, myrisfrageals A (562) and B (563), were isolated from the dried ripe seeds of Myristica fragrans Houtt. (Myristicaceae) and their absolute configurations determined by optical rotations and CD data. They showed inhibition of NO production in lipopolysaccharide activated murine monocyte macrophage RAW264.7 with $\mathrm{IC}_{50}$ of 76 and $45 \mu \mathrm{M}$, respectively. ${ }^{186}$ Ocophyllals A (564) and B (565) 
are dinor-benzofuran neolignan aldehydes isolated from the leaves of Ocotea macrophylla Kunth. ${ }^{179}$ The $7^{\prime}, 8^{\prime}, 9^{\prime}$-trinor- and $8^{\prime}, 9^{\prime}$-dinor-8,4-oxyneolignans 566 and 567, respectively and the $8^{\prime}, 9^{\prime}$-dinor-4, $8^{\prime \prime}$-oxy-8, $3^{\prime}$-sesquineolignan 568 are some of compounds isolated from stem of Sinocalamus affinis. ${ }^{112}$ Schischinone 569 is a 6,7-seco-homolignan, obtained from Schisandra chinensis (Turcz.) Baill. ${ }^{37}$ to derive biosynthetically from the eupadienone-type lignans as represented in Scheme 13. ${ }^{48}$ The isolated compounds were tested for their cytotoxic against HepG2 and Bcl7404 cell lines using an MTT assay. Gymnothelignan $\mathrm{C}$ exhibited moderate cytotoxicity against HepG2 and Bcl7404 cells with $\mathrm{IC}_{50}$ of 15 and $17 \mu \mathrm{g} \mathrm{mL} \mathrm{m}^{-1}$, respectively.<smiles>COc1cc(C(=O)O[C@@H](c2cc(OC)c(OC)c(OC)c2)[C@H](C)C(C)=O)cc(OC)c1OC</smiles>

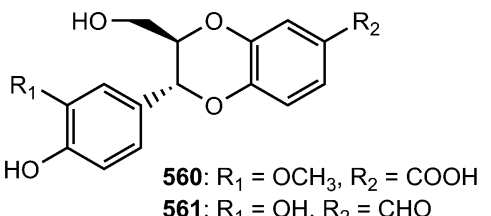

560: $\mathrm{R}_{1}=\mathrm{OCH}_{3}, \mathrm{R}_{2}=\mathrm{COOH}$
561: $\mathrm{R}_{1}=\mathrm{OH}, \mathrm{R}_{2}=\mathrm{CHO}$<smiles>COc1cc(C(=O)O[C@@H](c2cc(O)c(OC)c(OC)c2)[C@H](C)C(C)=O)cc(O)c1OC</smiles><smiles>[R]C[R16](=O)OC</smiles><smiles>COc1cc(C(=O)O[C@H](c2cc(O)c(OC)c(OC)c2)[C@H](C)C(C)=O)ccc1O</smiles><smiles>[R]c1cc(-c2oc3c(OC)cc(C=O)cc3c2C)cc([R])c1[R]</smiles>

564: $\mathrm{R}_{1}, \mathrm{R}_{2}=\mathrm{OCH}_{2} \mathrm{O} ; \mathrm{R}_{3}=\mathrm{H}$ 565: $\mathrm{R}_{1}=\mathrm{R}_{2}=\mathrm{R}_{3}=\mathrm{OCH}_{3}$

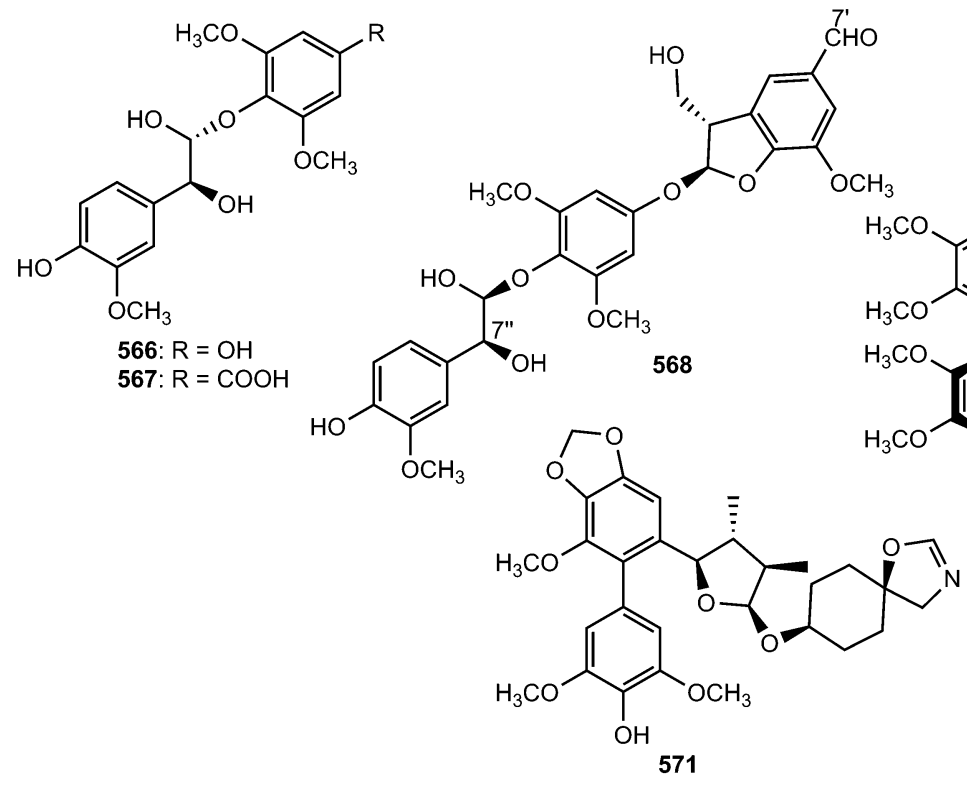

571<smiles>COc1cc(-c2c([C@@H]3O[C@@H]4O[C@H]5CC[C@]6(CN=CO6)C[C@H]5[C@H]4[C@H]3C)cc3c(c2OC)OCO3)cc(OC)c1O</smiles>

Gymnothelignans A-K (570-580), N (581) and O (582), bearing tetrahydrofuran with variable conformations, were isolated from Gymnotheca chinensis. ${ }^{48}$ The absolute configurations of these compounds were assigned using X-ray single crystal diffraction and chemical transformations. Gymnothelignans $\mathrm{N}$ and $\mathrm{O}$ are eupodienone lignans, a class of secondary metabolites previously isolated only from the Australian shrubs Eupomatia bennettii and Eupomatia laurina. ${ }^{187,188}$ The unusual tetrahydrofuran patterns in gymnothelignan A-K was believed
Two new eupodienone lignans, named gymnothelignans $\mathrm{T}$ (583) and gymnothelignan U (584), were also obtained from the endemic medicinal plant $G$. chinensis. Compound 583 showed moderate cytotoxic activity when tested against HCT15, HCT116, A549, MCF-7 and HepG2 cells with $\mathrm{IC}_{50}$ values above $50 \mu \mathrm{M} .{ }^{188}$ The absolute configuration of manglisin A (585) from the mature carpels of Manglietiastrum sinicum was assigned as $7 R, 8 R$ on the basis of X-ray diffraction using the Flack parameter $[0.06(9)]$ and $\mathrm{Cu} \mathrm{K} \alpha$ radiation. ${ }^{49}$ 
<smiles>COc1cc(-c2c([C@@H]3O[C@H](OC)[C@@H](C)[C@H]3C)cc(OC)c(OC)c2OC)cc(OC)c1O</smiles><smiles>COc1cc(-c2c([C@@H]3O[C@H](OC)[C@@H](C)[C@H]3C)cc3c(c2OC)OCO3)cc(OC)c1O</smiles><smiles>COc1cc(-c2c([C@@H]3O[C@H](OC)[C@@H](C)[C@H]3C)cc3c(c2OC)OCO3)cc(OC)c1O</smiles>

Systematic investigation on the EtOAc extract from Schisandra sphenanthera fruit was performed during a search for HSV-2 and adenovirus inhibitors leading to the rare lignan 586 which exhibited moderate inhibition. ${ }^{189}$ In addition to dibenzocyclooctadienes, norlignans named marphenols C-F (587-590) were isolated from the fruits of Schisandra wilsoniana. ${ }^{36} 5^{\prime} \alpha$ Hydroxy-4'-methoxy-sauchinone (591) and $5^{\prime} \beta$-hydroxy- $4^{\prime}$ methoxy-sauchinone (592) are from Saururus chinensis (Lour.) Baill. (Saururaceae), a perennial herb widely cultivated in China<smiles>[R]c1cc2c(c([R])c1[R])C1(C=C(OC)C(=O)C(OC)=C1)C(=O)[C@H](C)C(C)(C)[C@H]2O</smiles>

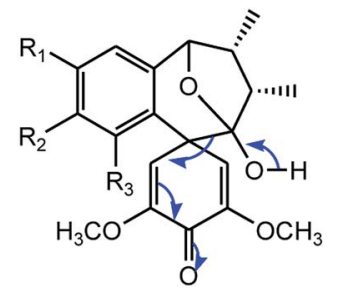

Gymnothelignan A-K

Reduction Substitution<smiles></smiles>

Scheme 13 Plausible biosynthetic pathways to gymnothelignans A-K.<smiles>COc1cc(-c2c([C@@H]3O[C@H](O)[C@@H](C)[C@H]3C)cc(OC)c(OC)c2OC)cc(OC)c1O</smiles>

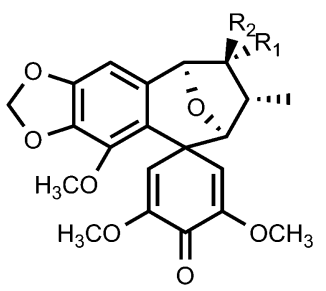

581: $\mathrm{R}_{1}=\mathrm{H}, \mathrm{R}_{2}=\mathrm{CH}_{3}$ 582: $\mathrm{R}_{1}=\mathrm{CH}_{3}, \mathrm{R}_{2}=\mathrm{H}$<smiles>COC1=C[C@@]2(C=CC1=O)[C@@H]1C=C[C@@]2(O)c2c(cc3c(c2OC)OCO3)[C@H](C)[C@@H]1C</smiles><smiles>COc1cc(C(c2ccc(OC)c(OC)c2)C(C)C(C)COC(C)=O)ccc1O</smiles><smiles>COCCCOC(C)=C(COC)OC</smiles><smiles></smiles>

583<smiles>COC1=CC2(C=C(OC)C1=O)C[C@H](C)[C@@H](C)Cc1cc3c(c(OC)c12)OCO3</smiles><smiles>[R]c1cc(C(O)C(C(=O)O)C(CO)CO)cc(OC)c1[R]</smiles>

587: $\mathrm{R}_{1}=\mathrm{OH}, \mathrm{R}_{2}=\mathrm{H}$ 588: $\mathrm{R}_{1}=\mathrm{OCH}_{3}, \mathrm{R}_{2}=\mathrm{OH}$<smiles>[R]c1ccc(C(=Cc2ccc(OC)c(O)c2)C(C(=O)O)C(CO)CO)cc1[R]</smiles>

589: $\mathrm{R}_{1}=\mathrm{OCH}_{3}, \mathrm{R}_{2}=\mathrm{OH}$

590: $R_{1}=R_{2}=O \mathrm{CH}_{2} \mathrm{O}$

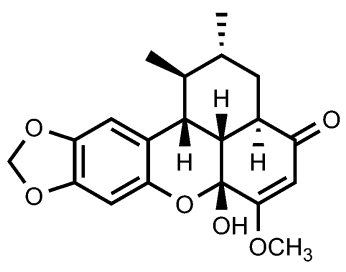

592

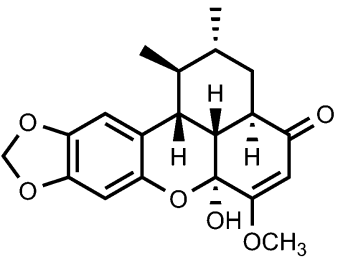

591

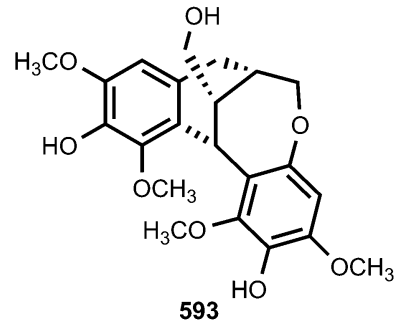


and southern Korea where it is used as folk medicine for the treatment of inflammation, jaundice and gonorrhea. The latter exhibited selective inhibitory activity on (diacylglycerol acyltransferase) DGAT1 with $\mathrm{IC}_{50}(87.5 \pm 1.3 \mu \mathrm{M})$, an enzyme which catalyzes the final step of the triacylglycerol synthesis pathway in mammalian cells by using diacylglycerol and fatty acyl CoA as substrates. ${ }^{190}$ The unusual cyclolignan (593) was also isolated from the stem of Sinocalamus affinis. ${ }^{\mathbf{1 1 2}}$

Two new sesqui-neolignans with novel conjugation patterns, simonols A (594) and B (595) were isolated from the ethanol extract of the fruits of Illicium simonii (Illiciaceae). Their structures were elucidated by spectroscopic methods including 1D and 2D NMR, HRESIMS, and calculation of ECD using density functional theory (DFT). Simonol A has a unique motif of a 5,5dihydropyran with a hemiketal carbon, while simonol B possesses two dihydrofuran rings in the same direction. ${ }^{191}$ Compound 594 showed moderate inhibitory activities comparable to 5-fluorouracil against the cancer cell lines NCI-H460, SMMC-7721, MCF-7, and BGC-823 ( IC $_{50}$ of 18, 17, 46 and $36 \mu \mathrm{M}$, respectively). The ethyl acetate fraction of Acorus tatarinowi Schott (Araceae) exhibited antihyperglycemic activity. Activityguided isolation furnished three novel sesquinlignans, tatanans A-C (596-598) with the unprecedented carbon skeleton as characterized by a unique $\mathrm{C} 8-\mathrm{C} 7^{\prime}$ linkage pattern. ${ }^{192}$ Their structures were established by spectroscopic techniques and single-crystal X-ray analysis. Tatanans A-C were evaluated for their in vitro antidiabetic activities, including GK activity,

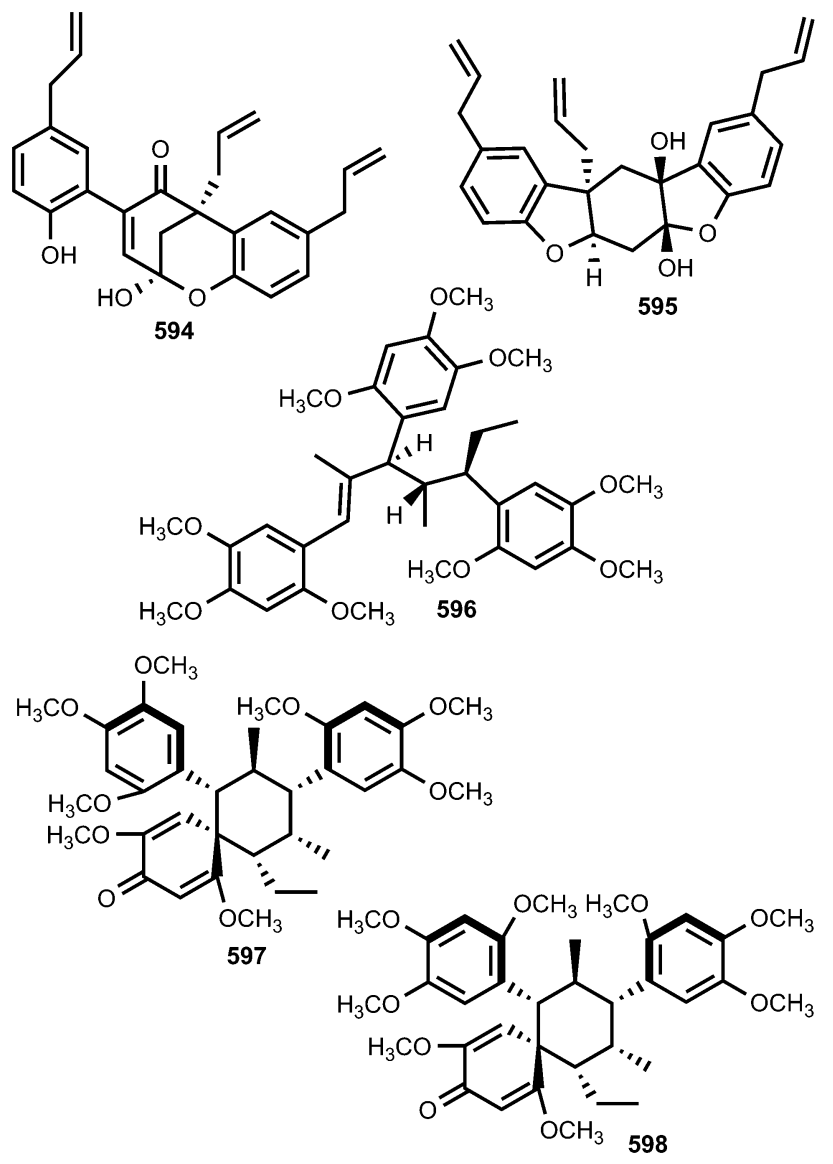

dipeptidyl-peptidase-4 (DPP-4) antagonist activity, $\alpha$-glycosidase inhibitory activity, $\mathrm{Na}^{+}$-glucose cotransporter (SGLT) antagonist activity, and aldose reductase inhibitory activity. Their activities were more potent than that of GKA22, one of the most potent GK activators reported in vitro to date, serving as a positive control. In addition, all metabolites were inactive against DPP4, $R$-glycosidase, SGLT, and aldose reductase. ${ }^{192}$

$( \pm)$-Torreyunlignans A-D $(\mathbf{5 9 9 a} / \mathbf{b}-602 \mathbf{a} / \mathbf{b})$ are four pairs of new 8-9' linked neolignan enantiomers featuring a rare $(E)-2$ styryl-1,3-dioxane moiety isolated from the trunk of Torreya yunnanensis (Taxaceae). ${ }^{193}$ The structures were determined by combined spectroscopic and chemical methods, and the absolute configurations elucidated by ECD calculations. Lignans featuring a C-8-C-9' linked skeleton are rarely found in nature, as only 18 examples of this chemotype have been reported. All of the enantiomers exhibited inhibition against phosphodiesterase-9A with $\mathrm{IC}_{50}$ values ranging from 5.6 to $15 \mu \mathrm{M} .{ }^{193}$<smiles>COc1ccccc1/C=C/[C@H]1CO[C@H](/C=C/c2ccccc2OC)O[C@H](c2ccc(OC)c(OC)c2)O1</smiles>
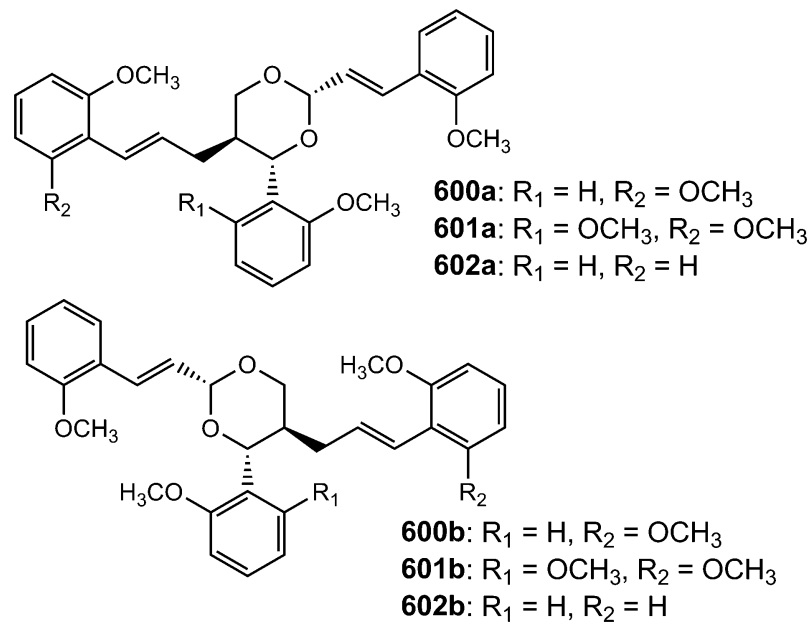

The neolignan chimarrhinin $\mathbf{6 0 3}$ with an unprecedented squeleton was obtained from the leaves of Chimarrhis turbinata, a Rubiaceae plant species. The antioxidant activity of the new derivative was investigated using $\mathrm{DPPH}$ and $\mathrm{an}^{\mathrm{IC}} \mathrm{IC}_{50}$ of $7.5 \pm 0.5$ $\mu \mathrm{M}$ was obtained. This result may be related to the presence of two catechol groups in the molecule. ${ }^{\mathbf{1 9 4}}$ Hovenins A-D (604-607) constitute two pairs of diastereomeric flavonolignans (a class of 
lignans biosynthetically produced by the oxidative coupling of a flavonoid and a phenylpropanoid) from the seeds of Hovenia acerba (Rhamnaceae). ${ }^{195}$ Their absolute configurations were determined with the aid of 2D NMR, and CD spectroscopy. These compounds showed better activity than silybin (SLB), and exhibited moderate inhibition on the production of NO and IL-6 in LPS-stimulated RAW264.7 cells with $\mathrm{IC}_{50}$ values ranging from 45 to $63 \mu \mathrm{M} .^{195}$

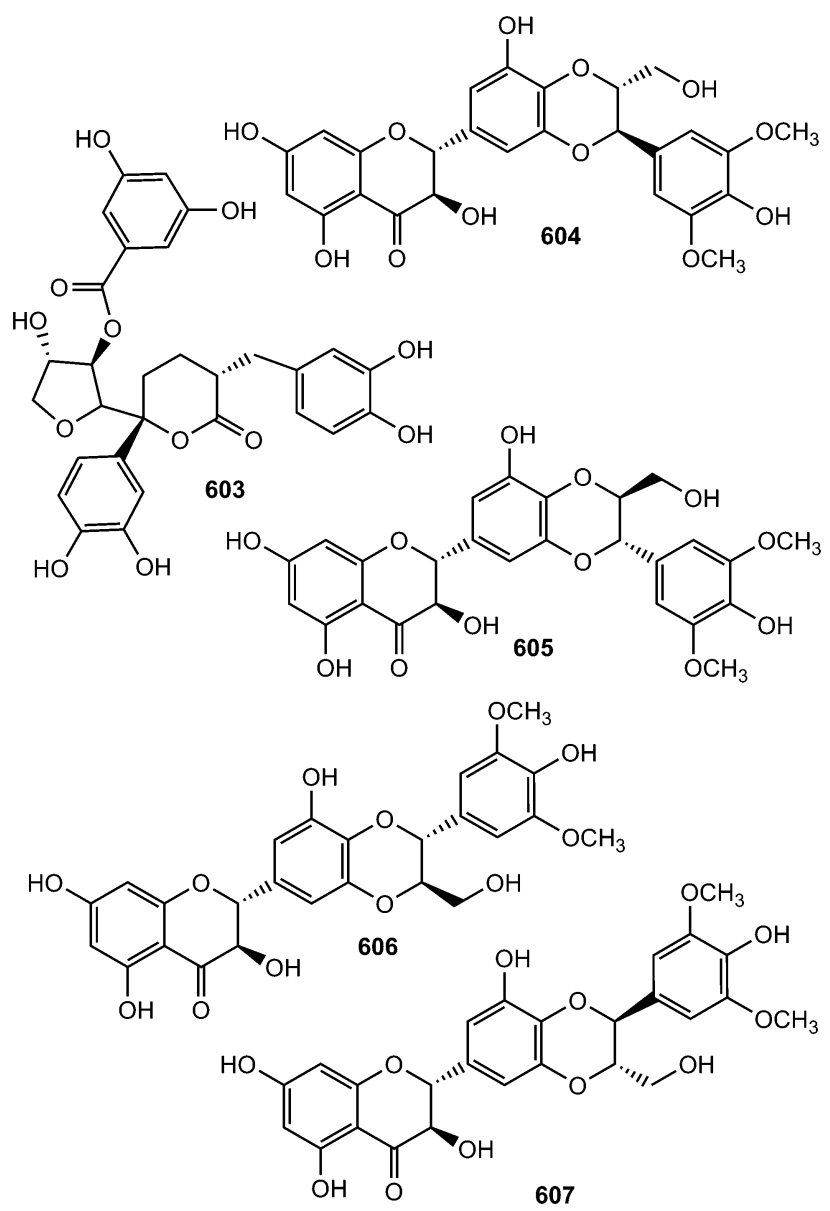

Other previously unreported flavonolignans include compounds 608-611 isolated from the ethanolic extract of the stem of Sinocalamus affinis ${ }^{\mathbf{1 1 2}}$ and anthelminthicol A (612) from the EtOAc extract of the seeds of Hydnocarpus anthelminthica (Flacourtiaceae). ${ }^{\mathbf{1 9 6}}$ The coumarinolignan cleomiscosin A methyl ether (613) was isolated from the methanolic extract of seeds of Hyoscyamus niger (Solanaceae). ${ }^{197}$ Uragogin (614), the first example of a triterpeneneolignan ester hetero-Diels-Alder adduct built with a dioxane bridge, was isolated from the EtOH extract of the stem of Crossopetalum uragoga (Celastraceae). Since the biosynthesis of dimeric and trimeric triterpenes containing a 1,4-dioxane bridge, which are chemotaxanomic markers of the Celastraceae species, has been hypothesized via DielsAlderase systems, uragogin could be formed by the reaction of trans-coniferyl acetate with caffeoyl-olean-12-ene as orthoquinone (Scheme 14). ${ }^{198}$

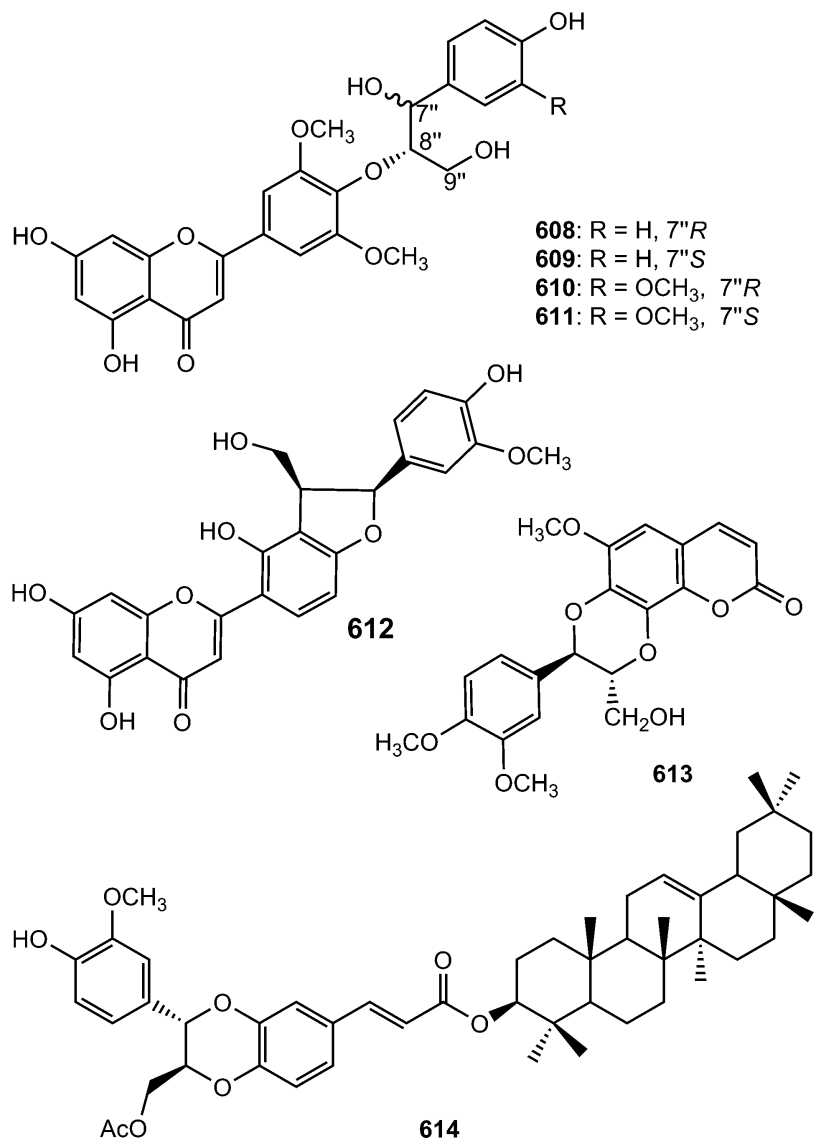

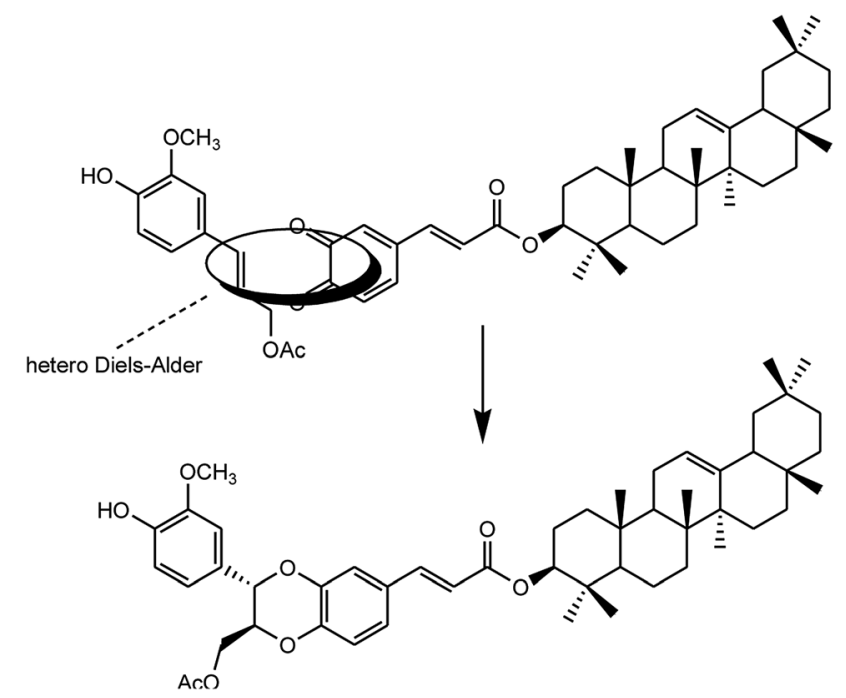

Scheme 14 Proposed biosynthesis of the 1,4-dioxane ring in uragogin.

\section{Outlook}

This review presents 564 examples of lignans and neolignans, including 131 dibenzocyclooctadienes from plants, reported between 2009 and 2015. Their relevant bioactivities are also indicated. In terms of structural diversity, the lignan and 
neolignan class of secondary metabolites has been enriched with some unprecedented carbon skeletons. For instance, ramonanins A-D (353-356) isolated from Guaiacum officinale, ${ }^{\mathbf{1 3 2}}$ or tatanans A-C (596-598) isolated from Acorus tatarinowi Schott $^{\mathbf{1 9 2}}$ have inimitable skeletons, while uragogin (614) represents the first example of a triterpene-neolignan ester hetero-Diels-Alder adduct built with a dioxane bridge. ${ }^{198}$ Furthermore, four rare furofuran dilignans, bearing an unusual $\alpha, \beta$-unsaturated ketone group, were isolated from Zanthoxylum podocarpum ${ }^{119,120}$ and Zanthoxylum planispinum. ${ }^{121}$ In addition to the new popophyllotoxin derivatives cleistantoxin (149) and 4-acetyl-4-demethyl-podophyllotoxin (155), the benzodioxanetype lignan $(7 R, 8 R)-5$-O-demethylbilagrewin (503) exhibited strong cytotoxic activity while $\left(7^{\prime} R, 8^{\prime} S, 7^{\prime \prime} R, 8^{\prime \prime} S\right)$-erythro strebluslignanol $G$ (517) showed significant anti-hepatitis B virus activity. These demonstrate the remarkable variety of lignans not only encompassing different and unique chemical scaffolds, but also exhibiting various functionalities worth exploitation by the pharmaceutical industries. For example, many of these compounds could be used as lead pro-drugs and further developed as new anticancer or antimicrobial agents, particularly at a time when microbial resistance is emergently causing global problems with few options of tackling the problem.

Despite the isolation and characterization of numerous lignans and neolignans in the last decade, a lot of work remains to be accomplished on this class of secondary metabolites particularly because they represent a huge resource of bioactive compounds. Since these compounds could mostly be obtained in small amounts from plants, one of the main challenges that need to be addressed in the future is their total synthesis in order to allow further bioactivity studies. However, lignans and neolignans are characterized by the stereoselective oxidative coupling of two phenylpropane units; the presence of chiral centres is an interesting challenge that needs to be overcome on a case-by-case basis for synthesizing these remarkable classes of compounds. Notably, during the last few years, total synthesis of several biologically active lignans and neolignans has already been achieved. This includes, for instance, a highly flexible and concise total synthesis of (+)-podophyllotoxin featuring an enantioselective sequential conjugate addition-allylation reaction, ${ }^{\mathbf{8 4}}$ a silver-catalyzed one-pot synthesis of a series of naturally occurring arylnaphthalene lignans, ${ }^{91}$ and an efficient and practical asymmetric synthesis of the 2,3-dihydrobenzo[b]furan neolignan acuminatin. ${ }^{157}$ Admittedly however, much remains to be learned about the biosynthetic pathway(s) leading to production of some of the recently-reported lignans/neolignans, which could be used in devising their total synthesis.

Another alternative source of lignans and neolignans could be their production from plant-associated microflora, in particular a diverse group of fungi and bacteria, called endophytes, which colonize living, internal plant tissues without causing abrupt, visible symptoms of disease within the hosts. In fact, the pharmacologically active arylnaphthalene lignan podophyllotoxin is already shown to be produced by several endophytic fungi, including Alternaria tenuissima isolated from Sinopodophyllum emodi (Wall.) Ying, ${ }^{199}$ and Mucor fragilis isolated from Sinopodophyllum hexandrum (Royle) Ying. ${ }^{200}$
Furthermore, some of us isolated and characterized the endophytic fungus Aspergillus fumigatus from the medicinal plant Juniperus communis, which is capable of producing the analogue of podophyllotoxin, called deoxypodophyllotoxin. ${ }^{201}$ Although this approach of using endophytes has been exploited by various researchers for sourcing known as well as novel lignans, commercial success is still limited due to low content of desired metabolites produced in vitro, recalcitrant nature and slow growth rate of many endophytes, genotypic variations, chemical instability, and complicated bioprocess design and downstream processing, among others. ${ }^{202}$

\section{Acknowledgements}

R. B. T. gratefully acknowledges the Alexander von Humboldt Foundation for granting a Georg Forster Research Fellowship for a research stay at the Institute of Environmental Research (INFU), Department of Chemistry and Chemical Biology, TU Dortmund. We are grateful to Prof. Dr Gail M. Preston (Department of Plant Sciences, University of Oxford, United Kingdom) for critically reviewing our manuscript and providing invaluable comments. We thank the anonymous reviewers for their critical comments and valuable advises. Notably, we have rounded off the bioactivities we report herein to two significant digits (wherever applicable) as recommended by one of the anonymous reviewers, which still convey the accuracy and comparability of the activities taking into consideration the variable nature and sensitivity of the assays.

\section{Notes and references}

1 C. Tringali, Bioactive Compounds from Natural Sources Isolation, Characterisation and Biological Properties, Corrado Tringali, first published 2001, Taylor \& Francis, New York, 2001.

2 J.-Y. Pan, S.-L. Chen, M.-H. Yang, J. Wu, J. Sinkkonen and K. Zoud, Nat. Prod. Rep., 2009, 26, 1251-1292.

3 R. Bernini, G. Gualandi, C. Crestini, M. Barontini, M. C. Belfiore, S. Willför, P. Eklund and R. Saladino, Bioorg. Med. Chem., 2009, 17, 5676-5682.

4 G. P. Moss, Pure Appl. Chem., 2000, 72, 1493-1523.

5 H. Satake, E. Ono and J. Murata, J. Agric. Food Chem., 2013, 61, 11721-11729.

6 H. Satake, T. Koyama, S. E. Bahabadi, E. Matsumoto, E. Ono and J. Murata, Metabolites, 2015, 5, 270-290.

7 A. Tsopmo, F. M. Awah and V. Kuete, in Medicinal Plant Research in Africa, ed. V. Kuete, Elsevier, Amsterdam, 2013, vol. 1, ch. 12, pp. 435-478.

8 T. Vogt, Mol. Plant, 2010, 3, 2-20.

9 A. A. Dar and N. Arumugam, Bioorg. Chem., 2013, 50, 1-10. 10 H. J. Kim, E. Ono, K. Morimoto, T. Yamagaki, A. Okazawa, A. Kobayashi and H. Satake, Plant Cell Physiol., 2009, 50, 2200-2209.

11 T. Umezawa, S. K. Ragamustari, T. Nakatsubo, S. Wada, L. Li, M. Yamamura, N. Sakakibara, T. Hattori, S. Suzuki and V. L. Chiang, Plant Biotechnol., 2013, 30, 97-109. 
12 S. K. Ragamustari, M. Yamamura, E. Ono, T. Hattori, S. Suzuki, H. Suzuki, D. Shibata and T. Umezawa, Plant Biotechnol., 2014, 31, 257-267.

13 K. Morimoto and H. Satake, Biol. Pharm. Bull., 2013, 36, 1519-1523.

14 S. K. Ragamustari, T. Nakatsubo, T. Hattori, E. Ono, Y. Kitamura, S. Suzuki, M. Yamamura and T. Umezawa, Plant Biotechnol., 2013, 30, 375-384.

15 J. V. Marques, K.-W. Kim, C. Lee, M. A. Costa, G. D. May, J. A. Crow, L. B. Davin and N. G. Lewis, J. Biol. Chem., 2013, 288, 466-479.

16 X. M. Gao, J. X. Pu, S. X. Huang, L. M. Yang, H. Huang, W. L. Xiao, Y. T. Zheng and H. D. Sun, J. Nat. Prod., 2008, 71, 558-563.

17 Y. C. Shen, Y. C. Lin, Y. B. Cheng, M. Y. Chiang, S. S. Liou and A. T. Khalil, Phytochemistry, 2009, 70, 114-120.

18 M. Chen, X. Xu, B. Xu, P. Yang, Z. Liao, S. L. MorrisNatschke, K.-H. Lee and D. Chen, Molecules, 2013, 18, 2297-2306.

19 Y. H. Kuo, H. C. Huang, L. M. Y. Kuo and C. F. Chen, J. Org. Chem., 1999, 64, 7023-7027.

20 D. E. Sok, H. S. Cui and M. R. Kim, Recent Pat. Food, Nutr. Agric., 2009, 1, 87-95.

21 A. Sibylle, S. Tatsuo, S. Marlen, R. Dagmar-Ulrike, P. Birgit and B. Volker, Arch. Gynecol. Obstet., 2012, 285, 1145-1151.

22 M. DellaGreca, S. Zuppolini and A. Zarrelli, Phytochem. Rev., 2013, 12, 717-731.

23 A. Khoddami, M. A. Wilkes and T. H. Roberts, Molecules, 2013, 18, 2328-2373.

24 L.-M. Y. Kuo, L.-J. Zhang, H.-T. Huang, Z.-H. Lin, C.-C. Liaw, H.-L. Cheng, K.-H. Lee, S. L. Morris-Natschke, Y.-H. Kuo and H.-O. Ho, J. Nat. Prod., 2013, 76, 580-587.

25 Y. Li, W. Cheng, C. Zhu, C. Yao, L. Xiong, Y. Tian, S. Wang, S. Lin, J. Hu, Y. Yang, Y. Guo, Y. Yang, Y. Li, Y. Yuan, N. Chen and J. Shi, J. Nat. Prod., 2011, 74, 1444-1452.

26 H. Liu, J. Zhang, X. Li, Y. Qi, Y. Peng, B. Zhang and P. Xiao, Phytomedicine, 2012, 19, 1234-1241.

27 T. J. Schmidt, S. Hemmati, M. Klaes, B. Konuklugil, A. Mohagheghzadeh, I. Ionkova, E. Fuss and A. W. Alfermann, Phytochemistry, 2010, 71, 1714-1728.

28 N. Cukelj, I. Jakasa, H. Sarajlija, D. Novotni and D. Curic, Talanta, 2011, 84, 127-132.

29 F. Bonzanini, R. Bruni, G. Palla, N. Serlataite and A. Caligiani, Food Chem., 2009, 117, 745-749.

30 G. Yuan, Y. Liu, T. Li, Y. Wang, Y. Sheng and G. Ming, Molecules, 2011, 16, 3713-3722.

31 J.-H. Yang, H.-Y. Zhang, J. Wen, X. Du, J.-H. Chen, H.-B. Zhang, W.-L. Xiao, J.-X. Pu, X.-C. Tang and H.-D. Sun, J. Nat. Prod., 2011, 74, 1028-1035.

32 J.-H. Yang, H.-Y. Zhang, J. Wen, X. Du, W. Wang, W.-L. Xiao, J. Wen, J.-X. Pu, X.-C. Tang and H.-D. Sun, Tetrahedron, 2011, 64, 4498-4504.

33 K. Dong, J.-X. Pu, H.-Y. Zhang, X. Du, X.-N. Li, J. Zou, J.-H. Yang, W. Zhao, X.-C. Tang and H.-D. Sun, J. Nat. Prod., 2012, 75, 249-256.
34 G.-Y. Yang, Y.-K. Li, R.-R. Wang, X.-N. Li, W.-L. Xiao, L.-M. Yang, J.-X. Pu, Y.-T. Zheng and H.-D. Sun, J. Nat. Prod., 2010, 73, 915-919.

35 W.-H. Ma, Y. Lu, H. Huang, P. Zhou and D.-F. Chen, Bioorg. Med. Chem. Lett., 2009, 19, 4958-4962.

36 G.-Y. Yang, R.-R. Wang, H.-X. Mu, Y.-K. Li, X.-N. Li, L.-M. Yang, Y.-T. Zheng, W.-L. Xiao and H.-D. Sun, J. Nat. Prod., 2013, 76, 250-255.

37 Y. Xue, X. Li, X. Du, X. Li, W. Wang, J. Yang, J. Chen, J. Pu and H. Sun, Phytochemistry, 2015, 116, 253-261.

38 Y. Ikeya, H. Taguchi, I. Yosioka, Y. Iitaka and H. Kobayashi, Chem. Pharm. Bull., 1979, 27, 1395-1401.

39 X.-N. Li, J.-X. Pu, X. Du, L.-M. Yang, H.-M. An, C. Lei, F. He, X. Luo, Y.-T. Zheng, Y. Lu, W.-L. Xiao and H.-D. Sun, J. Nat. Prod., 2009, 72, 1133-1141.

40 X.-M. Gao, R.-R. Wang, D.-Y. Niu, C.-Y. Meng, L.-M. Yang, Y.-T. Zheng, G.-Y. Yang, Q.-F. Hu, H.-D. Sun and W.-L. Xiao, J. Nat. Prod., 2013, 76, 1052-1057.

41 X.-M. Gao, D.-Y. Niu, C.-Y. Meng, F.-Q. Yao, B. Zhou, R.-R. Wang, L.-M. Yang, Y.-T. Zheng, Q.-F. Hu, H.-D. Sun and W.-L. Xiao, J. Braz. Chem. Soc., 2013, 24, 2021-2027.

42 M. Chen, X. M. Xu, Z. H. Liao, L. Dong, L. Li and C. Z. Huang, Molecules, 2008, 13, 548-555.

43 Y.-B. Cheng, M.-T. Chang, Y.-W. Lo, C.-J. Ho, Y.-C. Kuo, C.-T. Chien, S.-Y. Chen, S.-S. Liou, Y.-H. Kuo and Y.-C. Shen, J. Nat. Prod., 2009, 72, 1663-1668.

44 D. Hu, Z. Yang, X. Yao, H. Wang, N. Han, Z. Liu, Y. Wang, J. Yang and J. Yin, Phytochemistry, 2014, 104, 72-78.

45 H. M. Kim, B. Ryu, J. S. Lee, J. H. Choi and D. S. Jang, Chem. Pharm. Bull., 2015, 63, 746-751.

46 G.-Y. Yang, P. Fan, R.-R. Wang, J.-L. Cao, W.-L. Xiao, L.-M. Yang, J.-X. Pu, Y.-T. Zheng and H.-D. Sun, Chem. Pharm. Bull., 2010, 58, 734-737.

47 L. Fang, C. Xie, H. Wang, D.-Q. Jin, J. Xu and Y. Guo, Phytochem. Lett., 2014, 9, 158-162.

48 D. He, L. Ding, H. Xu, X. Lei, H. Xiao and Y. Zhou, J. Org. Chem., 2012, 77, 8435-8443.

49 J.-Y. Ding, C.-M. Yuan, M.-M. Cao, W.-W. Liu, C. Yu, H.-Y. Zhang, Y. Zhang, Y.-T. Di, H.-P. He, S.-L. Li and X.-J. Hao, J. Nat. Prod., 2014, 77, 1800-1805.

50 W. Schühly, B. Gröblacher, J. Neyer, W. M. F. Fabian, F. R. Fronczek and O. Kunert, Phytochemistry, 2010, 71, 1787-1795.

51 Y.-C. Lin, Y.-B. Cheng, C.-C. Liaw, I.-W. Lo, Y.-H. Kuo, M. Y. Chiang, C. H. Chou and Y.-C. Shen, Molecules, 2013, 18, 6573-6583.

52 Y. Ikeya, H. Taguchi, I. Yosioka and H. Kobayashi, Chem. Pharm. Bull., 1979, 27, 1383-1394.

53 M. Blunder, E. M. Pferschy-Wenzig, W. M. F. Fabian, A. Hüfner, O. Kunert, R. Saf, W. Schühly and R. Bauer, Bioorg. Med. Chem., 2010, 18, 2809-2815.

54 A. Fürstner and G. Seidel, J. Org. Chem., 1997, 62, 23322336.

55 K. Kashima, K. Sano, Y. S. Yun, H. Ina, A. Kunugi and H. Inoue, Chem. Pharm. Bull., 2010, 58, 191-194. 
56 L.-M. Y. Kuo, L.-J. Zhang, H.-T. Huang, Z.-H. Lin, C.-C. Liaw, H.-L. Cheng, K.-H. Lee, S. L. Morris-Natschke, Y.-H. Kuo and H.-O. Ho, J. Nat. Prod., 2013, 76, 580-587.

57 E. C. N. Nono, P. Mkounga, V. Kuete, K. Marat, P. G. Hultin and A. E. Nkengfack, J. Nat. Prod., 2010, 73, 213-216.

58 V. T. T. Thanh, V. C. Pham, H. D. T. Mai, M. Litaudon, F. Gueritte, P. Retailleau, V. H. Nguyen and V. M. Chau, J. Nat. Prod., 2012, 75, 1578-1583.

59 Q. L. Ying, Y. Liu and T. Xuan, Curr. Bioact. Compd., 2007, 3, 37-66.

60 T. Rezanka, P. Rezanka and K. Sigler, Phytochemistry, 2009, 70, 1049-1054.

61 Y.-J. Sun, Z.-L. Li, H. Chen, X.-Q. Liu, W. Zhou and H.-M. Hua, Bioorg. Med. Chem. Lett., 2011, 21, 3794-3797.

62 X. Zeng, H. Wang, Z. Gong, J. Huang, W. Pei, X. Wang, J. Zhang and X. Tang, Fitoterapia, 2015, 101, 153-161.

63 S. Takahashi, S. Kawakami, S. Sugimoto, K. Matsunami and H. Otsuka, Am. J. Plant Sci., 2015, 6, 676-684.

64 M. D. P. Pereira, M. R. Ferreira, G. B. Messiano, I. P. Ceravolo, L. M. X. Lopes and A. U. Krettli, Phytochem. Lett., 2015, 13, 200-205.

65 H. Z. Li, G. J. Luo, H. M. Li, X. L. Li and R. T. Li, Chin. Chem. Lett., 2011, 22, 85-87.

66 C. Q. Zhao, Y. Y. Zhu, S. Y. Chen and Y. Ogihara, Chin. Chem. Lett., 2011, 22, 181-184.

67 M. Omar, Y. Matuo, H. Maeda, Y. Saito and T. Tanaka, Phytochem. Lett., 2013, 6, 486-490.

68 J. Zhou, C.-J. Li, J.-Z. Yang, J. Ma, L.-Q. Wu, W.-J. Wang and D.-M. Zhang, Phytochemistry, 2016, 121, 58-64.

69 Y.-N. Yang, Z.-Z. Liu, Z.-M. Feng, J.-S. Jiang and P.-C. Zhang, J. Agric. Food Chem., 2012, 60, 964-972.

70 H. Jin, H.-L. Yin, S.-J. Liu, L. Chen, Y. Tian, B. Li, Q. Wang and J.-X. Dong, Fitoterapia, 2014, 94, 70-76.

71 J.-L. Wu, S. Jun-ichi and A. Masayoshi, J. Nat. Prod., 2006, 69, 790-794.

72 W. S. Suh, K. H. Kim, H. K. Kim, S. U. Choi and K. R. Lee, Helv. Chim. Acta, 2015, 98, 1087-1094.

73 K. H. Kim, E. Moon, S. Y. Kim, S. U. Choi and K. R. Lee, Food Chem. Toxicol., 2012, 50, 3680-3686.

74 W.-J. Tsai, C.-C. Shen, T.-H. Tsai and L.-C. Lin, J. Nat. Prod., 2014, 77, 125-131.

75 S. H. Park, S. K. Ko and S. H. Chung, J. Ethnopharmacol., 2005, 102, 326-335.

76 E. J. Jeong, J. H. Cho, S. H. Sung, S. Y. Kim and Y. C. Kim, Bioorg. Med. Chem. Lett., 2011, 21, 2283-2286.

77 K. Yoshikawa, S. Tani, C. Baba and T. Hashimoto, Molecules, 2013, 18, 9641-9649.

78 Y. Ren, D. D. Lantvit, Y. Deng, R. Kanagasabai, J. C. Gallucci, T. N. Ninh, H.-B. Chai, D. D. Soejarto, J. R. Fuchs, J. C. Yalowich, J. Yu, S. M. Swanson and A. D. Kinghorn, J. Nat. Prod., 2014, 77, 1494-1504.

79 M. Kumar, P. Rawat, N. Rahuja, A. K. Srivastava and R. Maurya, Phytochemistry, 2009, 70, 1448-1455.

80 H. L. Holland, E. J. Bergen, P. C. Chenchaiah, S. H. Khan, B. Munoz, R. W. Ninniss and D. Richards, Can. J. Chem., 1987, 65, 502-507.
81 G. B. Messiano, E. M. K. Wijeratne, L. M. X. Lopes and A. A. L. Gunatilaka, J. Nat. Prod., 2010, 73, 1933-1937.

82 Y.-Q. Liu, L. Yang and X. Tian, Curr. Bioact. Compd., 2007, 3, 37-66.

83 A. M. Rojas-Sepúlveda, M. Mendieta-Serrano, M. Y. Antúnez Mojica, E. Salas-Vidal, S. Marquina, M. L. Villarreal, A. M. Puebla, J. I. Delgado and L. Alvarez, Molecules, 2012, 17, 9506-9519.

84 Y. Wu, J. Zhao, J. Chen, C. Pan, L. Li and H. Zhang, Org. Lett., 2009, 11, 597-600.

85 C. Agami, S. Comesse and C. Kadouri-Puchot, J. Org. Chem., 2002, 67, 1496-1500.

86 H. Joseph, J. Gleye, C. Moulis, L. J. Mensah, C. Roussakis and C. Gratas, J. Nat. Prod., 1988, 51, 599-600.

87 C. W. Chang, M. T. Lin, S. S. Lee, K. C. S. C. Liu, F. L. Hsu and J. Y. Lin, Antiviral Res., 1995, 27, 367-374.

88 J. Gertsch, R. T. Tobler, R. Brun, O. Sticher and J. Heilmann, Planta Med., 2003, 69, 420-424.

89 J. R. Weng, H. H. Ko, T. L. Yeh, C. H. Lin and C. N. Lin, Arch. Pharm. Pharm. Med. Chem., 2004, 337, 207-212.

90 P. Foley, N. Eghbali and P. T. Anastas, Green Chem., 2010, 12, 888-892.

91 P. Foley, N. Eghbali and P. T. Anastas, J. Nat. Prod., 2010, 73, 811-813.

92 L. F. L. Barros, A. Barison, M. J. Salvador, R. De Mello-Silva, E. C. Cabral, M. N. Eberlin and M. A. Stefanello, J. Nat. Prod., 2009, 72, 1529-1532.

93 K. Jiang, Q.-Y. Song, S.-J. Peng, Q.-Q. Zhao, G.-D. Li, Y. Li and K. Gao, Fitoterapia, 2015, 103, 63-70.

94 J. S. Lee, M. S. Huh, Y. C. Kim, M. Hattori and T. Otake, Antiviral Res., 2010, 85, 425-428.

95 Y.-B. Xue, Y.-L. Zhang, J.-H. Yang, X. Du, J.-X. Pu, W. Zhao, X.-N. Li, W.-L. Xiao and H.-D. Sun, Chem. Pharm. Bull., 2010, 58, 1606-1611.

96 A. Yokosuka, Y. Matsuo, M. Jitsuno, K. Adachi and Y. Mimaki, Chem. Pharm. Bull., 2011, 59, 1467-1470.

97 D.-T. Yang, S.-S. Lin, J.-H. Chen, S.-T. Yuan, J.-S. Shi, J.-S. Wang and A.-Q. Jia, Bioorg. Med. Chem. Lett., 2015, 25, 1976-1978.

98 C. S. Kim, O. W. Kwon, S. Y. Kim and K. R. Lee, J. Nat. Prod., 2013, 76, 2131-2135.

99 B. J. Cabanillas, A.-C. Le Lamer, D. Castillo, J. Arevalo, R. Rojas, G. Odonne, G. Bourdy, B. Moukarzel, M. Sauvain and N. Fabre, J. Nat. Prod., 2010, 73, 1884-1890.

100 M. S. C. Pedras and Q.-A. Zheng, Phytochemistry, 2010, 71, 581-589.

101 C. Zhu, L. Jing, N. Yu, X. Yang and Y. Zhao, Acta Pharm. Sin. $B, 2013,3,109-112$.

102 C.-I. Chang, Y.-C. Li, C.-C. Kuo, C.-Y. Chao, H.-S. Chang, J.-H. Wu, S.-Y. Wang and Y.-H. Kuo, Nat. Prod. Commun., 2013, 8, 1-2.

103 Y.-Y. Yang, X.-Y. Huang, Z.-M. Feng, J.-S. Jiang and P.-C. Zhang, J. Agric. Food Chem., 2015, 63, 7958-7966.

104 O. P. Mishra, N. Simmons, S. Tyagi, R. Pietrofesa, V. V. Shuvaev, R. A. Valiulin, P. Heretsch, K. C. Nicolaou and M. Christofidou-Solomidou, Bioorg. Med. Chem. Lett., 2013, 23, 5325-5328. 
105 J. Rajesha, K. N. Murthy, M. K. Kumar, B. Madhusudhan and G. A. Ravishankar, J. Agric. Food Chem., 2006, 54, 3794-3799.

106 S. S. Moree and J. Rajesha, Mol. Cell. Biochem., 2013, 373, 179-187.

107 K. Prasad, Mol. Cell. Biochem., 1997, 168, 117-123.

108 E. Lee, V. S. J. Ahamed, M. S. Kumar, S. W. Rhee, S.-S. Moon and I. S. Hong, Bioorg. Med. Chem. Lett., 2011, 21, 62456249.

109 J. Y. Kim, H. J. Lim, D. Y. Lee, J. S. Kim, D. H. Kim, H. J. Lee, H. D. Kim, R. Jeon and J.-H. Ryu, Bioorg. Med. Chem. Lett., 2009, 19, 937-940.

110 A. Stojakowska, K. Michalska, J. Malarz, A. Beharav and W. Kisiel, Food Chem., 2013, 138, 1250-1255.

111 R.-O. Mei, Y.-H. Wang, G.-H. Du, G.-M. Liu, L. Zhang and Y.-X. Cheng, J. Nat. Prod., 2009, 72, 621-625.

112 L. Xiong, C. Zhu, Y. Li, Y. Tian, S. Lin, S. Yuan, J. Hu, Q. Hou, N. Chen, Y. Yang and J. Shi, J. Nat. Prod., 2011, 74, 1188-1200.

113 S. S. Hong, C. Lee, C. H. Lee, M. Park, M. S. Lee, J. T. Hong, H. Lee, M. K. Lee and B. Y. Hwang, Arch. Pharmacal Res., 2009, 32, 501-504.

114 Y. Lu, Y. Xue, J. Liu, G. Yao, D. Li, B. Sun, J. Zhang, Y. Liu, C. Qi, M. Xiang, Z. Luo, G. Du and Y. Zhang, J. Nat. Prod., 2015, 78, 2205-2214.

115 P.-H. Nguyen, J.-L. Yang, M. N. Uddin, S.-L. Park, S.-Il Lim, D.-W. Jung, D. R. Williams and W.-K. Oh, J. Nat. Prod., 2013, 76, 2080-2087.

116 X. Sun, G. Ma, D. Zhang, W. Huang, G. Ding, H. Hu, G. Tu and B. Guo, Molecules, 2015, 20, 2165-2175.

117 P. Luecha, K. Umehara, T. Miyase and H. Noguchi, J. Nat. Prod., 2009, 72, 1954-1959.

118 K. H. Kim, E. Moon, S. Y. Kim and K. R. Lee, J. Agric. Food Chem., 2010, 58, 4779-4785.

119 X.-J. Zhou, X.-L. Chen, X.-S. Li, J. Su, J.-B. He, Y.-H. Wang, Y. Li and Y.-X. Cheng, Bioorg. Med. Chem. Lett., 2011, 21, 373-376.

120 X.-J. Zhou, X.-L. Chen, X.-S. Li, J. Su, J.-B. He, Y.-H. Wang, Y. Li and Y.-X. Cheng, Bioorg. Med. Chem. Lett., 2013, 23, 5452 .

121 G.-Y. Su, K.-W. Wang, X.-Y. Wang and B. Wu, Phytochem. Lett., 2015, 11, 120-126.

122 T. Sasakia, W. Li, a. S. Zaike, Y. Asada, Q. Li, F. Ma, Q. Zhang and K. Koike, Phytochemistry, 2013, 95, 333-340.

123 Y.-N. Yang, X.-Y. Huang, W.-M. Feng, J.-S. Jiang and P.-C. Zhang, J. Agric. Food Chem., 2014, 62, 9095-9102.

124 K. H. Kim, E. Moon, S. K. Ha, W. S. Suh, H. K. Kim, S. Y. Kim, S. U. Choi and K. R. Lee, Chem. Pharm. Bull., 2014, 62, 1136-1140.

125 K. Sawasdee, T. Chaowasku, V. Lipipun, T.-H. Dufat, S. Michel and K. Likhitwitayawuid, Tetrahedron Lett., 2013, 54, 4259-4263.

126 X.-Y. Huang, Z.-M. Feng, Y.-N. Yang, J.-S. Jiang and P.-C. Zhang, J. Asian Nat. Prod. Res., 2015, 17, 504-511.

127 K. H. Kim, H. K. Kim, S. U. Choi, E. Moon, S. Y. Kim and K. R. Lee, J. Nat. Prod., 2011, 74, 2187-2192.
128 Y. Ren, H. Chai, M. Goetz and A. D. Kinghorn, Tetrahedron Lett., 2013, 54, 4854-4858.

129 Y.-T. Huang, H.-S. Chang, G.-J. Wang, M.-J. Cheng, C.-H. Chen, Y.-J. Yang and I.-S. Chen, J. Nat. Prod., 2011, 74, 1875-1880.

130 M. DellaGreca, A. Mancino, L. Previtera, A. Zarrelli and S. Zuppolini, Phytochem. Lett., 2011, 4, 118-121.

131 H. Wang, C.-A. Geng, H.-B. Xu, X.-Y. Huang, Y.-B. Ma, C.-Y. Yang, X.-M. Zhang and J.-J. Chen, Planta Med., 2015, 81, 847-854.

132 K. J. Chavez, X. Feng, J. A. Flanders, E. Rodriguez and F. C. Schroeder, J. Nat. Prod., 2011, 74, 1293-1297.

133 A. K. F. Albertson and J.-P. Lumb, Angew. Chem., Int. Ed., 2015, 54, 2204-2208.

134 K. Sawasdee, T. Chaowasku, V. Lipipun, T.-H. Dufat, S. Michel and K. Likhitwitayawuid, Fitoterapia, 2013, 85, 49-56.

135 H. Zhao, T. Nie, H. Guo, J. Li and H. Bai, Phytochem. Lett., 2012, 5, 240-243.

136 C. Lee, J. W. Lee, Q. Jin, H. J. Lee, S.-J. Lee, D. Lee, M. K. Lee, C. K. Lee, J. T. Hong, M. K. Lee and B. Y. Hwang, Bioorg. Med. Chem. Lett., 2013, 23, 6010-6014.

137 G.-H. Tang, Z.-W. Chen, T.-T. Lin, M. Tan, X.-Y. Gao, J.-M. Bao, Z.-B. Cheng, Z.-H. Sun, G. Huang and S. Yin, J. Nat. Prod., 2015, 78, 1894-1903.

138 H.-G. Jin, A. R. Kim, H. J. Ko, S. K. Lee and E.-R. Woo, Chem. Pharm. Bull., 2014, 62, 288-293.

139 L. Wang, F. Li, C.-Y. Yang, A.-A. Khan, X. Liu and M.-K. Wang, Fitoterapia, 2014, 99, 92-98.

140 T. Yuan, C. Wan, A. G. Ez-Sarria, V. Kandhi, N. B. Cech and N. P. Seeram, J. Nat. Prod., 2011, 74, 2472-2476.

141 C.-W. Song, S.-M. Wang, L.-L. Zhou, F.-F. Hou, K.-J. Wang, Q.-B. Han, N. Li and Y.-X. Cheng, J. Agric. Food Chem., 2011, 59, 1199-1204.

142 W.-J. Xiang, L. Ma and L.-H. Hu, Fitoterapia, 2010, 81, 12281231.

143 J. G. S. Filho, S. L. Nimmo, H. S. Xavier, J. M. Barbosa-Filho and R. H. Cichewicz, J. Nat. Prod., 2009, 72, 1344-1347.

144 X. Li, J.-G. Luo, X.-B. Wang, J. Luo, J.-S. Wang and L.-Y. Kong, Fitoterapia, 2012, 83, 883-887.

145 Y.-S. Shi, Y.-B. Liu, S.-G. Ma, Y. Li, J. Qu, L. Li, S.-P. Yuan, Q. Hou, Y.-H. Li, J.-D. Jiang and S.-S. Yu, J. Nat. Prod., 2015, 78, 1526-1535.

146 S. Baek, X. Xia, B. S. Min, C. Park and S. H. Shim, Beilstein J. Org. Chem., 2014, 10, 2955-2962.

147 Y. Wu, C. Liu, H.-F. Li, J.-B. Sun, Y.-Y. Li, W. Gu, D.-Y. Wang, J.-G. Liu and Y.-L. Hu, Biochem. Syst. Ecol., 2014, 55, 41-45.

148 X. Liu, M.-H. Yang, X.-B. Wang, S.-S. Xie, Z.-R. Li, D.-H. Kim, J.-S. Park and L.-Y. Kong, Fitoterapia, 2015, 103, 136-142.

149 A. Solyomvary, G. Toth, B. Komjati, P. Horvath, M. Kraszni, B. Noszal, I. Molnar-Perl and I. Boldizsar, Proc. Biochem., 2015, 50, 853-858.

150 K. W. Woo, S. U. Choi, J. C. Park and K. R. Lee, Arch. Pharmacal Res., 2011, 34, 2043-2049.

151 Y.-L. Li, Y.-X. Gao, H.-Z. Jin, L. Shan, W.-L. Chang, X.-W. Yang, H.-W. Zeng, N. Wang, A. Steinmetz and W.-D. Zhang, Phytochemistry, 2015, 117, 135-143. 
152 L. H. Rakotondraide, P. R. Graupner, Q. Xiong, M. Olson, J. D. Wiley, P. Krai, P. J. Brodie, M. W. Callmander, E. Rakotobe, F. Ratovoson, V. E. Rasamison, M. B. Cassera, D. R. Hahn, D. G. I. Kingston and S. Fotso, J. Nat. Prod., 2015, 78, 431-440.

153 X.-X. Huang, C.-C. Zhou, L.-Z. Li, Y. Peng, L.-L. Lou, S. Liu, D.-M. Li, T. Ikejima and S.-J. Song, Fitoterapia, 2013, 91, 217-223.

154 S. Rattanaburi, W. Mahabusarakam, S. Phongpaichit and A. R. Carroll, Phytochem. Lett., 2012, 5, 18-21.

155 T. Murata, K. Oyama, M. Fujiyama, B. Oobayashi, K. Umehara, T. Miyase and F. Yoshizaki, Fitoterapia, 2013, 91, 51-59.

156 Rudiyansyah, L. K. Lambert and M. J. Garson, J. Nat. Prod., 2010, 73, 1649-1654.

157 C. Lopez-Sanchez, M. Alvarez-Corral, L. Jimenez-Gonzalez, M. Munoz-Dorado and I. Rodríguez-García, Tetrahedron, 2013, 69, 5511-5516.

158 J. R. Fulton, V. K. Aggarwal and J. de Vicente, Eur. J. Org. Chem., 2005, 2005, 1479-1492.

159 V. A. Yap, B.-J. Loong, K.-N. Ting, S. H.-S. Loh, K.-T. Yong, Y.-Y. Low, T.-S. Kam and K.-H. Lim, Phytochemistry, 2015, 109, 96-102.

160 G.-Y. Cao, W. Xu, X.-W. Yang, F. J. Gonzalez and F. Li, Food Chem., 2015, 173, 231-237.

161 X.-X. Huang, C.-C. Zhou, L.-Z. Li, F.-F. Li, L.-L. Lou, D.-M. Li, T. Ikejima, Y. Peng and S.-J. Song, Bioorg. Med. Chem. Lett., 2013, 23, 5599-5604.

162 X.-S. Feng, Y. Qu, L. Xu, D.-C. Wang, L.-J. Wu, F.-H. Meng and Y.-R. Liu, Molecules, 2009, 14, 953-958.

163 J. F. Liao, S. Y. Huang, Y. M. Jan, L. L. Yu and C. F. Chen, J. Ethnopharmacol., 1998, 61, 185-193.

164 K. H. Kim, E. Moon, H. K. Kim, J. Y. Oh, S. Y. Kim, S. U. Choi and K. R. Lee, Bioorg. Med. Chem. Lett., 2012, 22, 6155-6159.

165 C.-B. Xue, D.-W. Chai, X.-J. Jin, Y.-R. Bi, X.-J. Yao, W.-S. Wu and Y. Zhu, Phytochemistry, 2011, 72, 1804-1813.

166 J. Shu, F. Liang, J. Liang, Y. Liang, F. Li, F. Shao, R. Liu and H. Huang, Fitoterapia, 2015, 104, 64-68.

167 W.-H. Cai, K. Matsunami, H. Otsuka and Y. Takeda, Am. J. Plant Sci., 2011, 2, 609-618.

168 N. H. Tung, Y. Ding, E. M. Choi, C. V. Minh and Y. H. Kim, Chem. Pharm. Bull., 2009, 57, 65-68.

169 A. Stochmal, I. Kowalska, B. Janda, A. Perrone, S. Piacente and W. Oleszek, Phytochemistry, 2009, 70, 1272-1276.

170 W. Schuehly, W. Voith, H. Teppner and O. Kunert, J. Nat. Prod., 2010, 73, 1381-1384.

171 L. I. Pilkington and D. Barker, Nat. Prod. Rep., 2015, 32, 1369-1388.

172 Y. Matsuo and Y. Mimaki, Chem. Pharm. Bull., 2010, 58, 587-590.

173 J.-S. Bae and T. H. Kim, Bioorg. Med. Chem. Lett., 2012, 22, 793-796.

174 J. Li, Y. Huang, X.-L. Guan, J. Li, S.-P. Deng, Q. Wu, Y.-J. Zhang, X.-J. Su and R.-Y. Yang, Phytochemistry, 2012, 82, 100-109.
175 H. Chen, J. Li, Q. Wu, X.-T. Niu, M.-T. Tang, X.-L. Guan, J. Li, R.-Y. Yang, S.-P. Deng and X.-J. Su, Fitoterapia, 2012, 83, 643-649.

176 M. Hosseinzadeh, J. Mohamad, M. A. Khalilzadeh, M. R. Zardoost, J. Haak and M. Rajabi, J. Photochem. Photobiol., B, 2013, 128, 85-91.

177 J. Li, A.-P. Meng, X.-L. Guan, J. Li, Q. Wu, S.-P. Deng, X.-J. Su and R.-Y. Yang, Bioorg. Med. Chem. Lett., 2013, 23, 22382244.

178 S. Chen, H.-Y. Huang, M.-J. Cheng, C.-C. Wu, T. Ishikawa, C.-F. Peng, H.-S. Chang, C.-J. Wang, S.-L. Wong and I.-S. Chen, Phytochemistry, 2013, 93, 203-309.

179 E. D. Coy-Barrera, L. E. Cuca-Suárez and M. Sefkow, Phytochemistry, 2009, 70, 1309-1314.

180 E. D. C. Barrera and L. E. C. Suarez, Chem. Pharm. Bull., 2009, 57, 639-642.

181 J.-J. Xu, G.-Z. Zeng, S.-C. Yang, Y. Shen and N.-H. Tan, Fitoterapia, 2013, 91, 82-86.

182 Y.-C. He, Y. Zou, C. Peng, J.-L. Liu, C.-J. He, L. Guo, X.-F. Xie and L. Xiong, Fitoterapia, 2015, 100, 7-10.

183 A. E. Do Vale, J. M. David, E. O. Dos Santos, J. P. David, L. C. R. C. Silva, M. V. Bahia and H. N. Brandão, Phytochemistry, 2012, 76, 158-161.

184 Y.-M. Chung, H.-C. Wang, M. El-Shazly, Y.-L. Leu, M.-C. Cheng, C.-L. Lee, F.-R. Chang and Y.-C. Wu, J. Agric. Food Chem., 2011, 69, 9219-9225.

185 Y. Deng, Y.-W. Chin, H.-B. Chai, E. C. De Blanco, L. B. S. Kardono, S. Riswan, D. D. Soejarto, N. R. Farnsworth and A. D. Kinghorn, Phytochem. Lett., 2011, 4, 213-217.

186 G.-Y. Cao, X.-W. Yang, W. Xu and F. Li, Food Chem. Toxicol., 2013, 62, 167-171.

187 A. R. Carroll and W. C. Taylor, Aust. J. Chem., 1991, 44, 1627-1633.

188 S.-J. Xiao, F. Chen, L.-S. Ding and Y. Zhou, Chin. Chem. Lett., 2014, 25, 463-464.

189 Q.-Y. Song, C.-J. Zhang, Y. Li, J. Wen, X.-W. Zhao, Z.-L. Liu and K. Gao, Phytochem. Lett., 2013, 6, 174-178.

190 N. Li, Z.-D. Tuon, S.-Z. Qi, S.-S. Xing, H.-S. Lee, J.-G. Chen and L. Cui, Fitoterapia, 2015, 101, 46-50.

191 P.-J. Yin, J.-S. Wang, D.-D. Wei, Y. Zhang, P.-R. Wang, X.-B. Wang and L.-Y. Kong, Fitoterapia, 2013, 88, 31-37.

192 G. Ni, Z.-F. Shen, Y. Lu, Y.-H. Wang, Y.-B. Tang, R.-Y. Chen, Z.-Y. Hao and D.-Q. Yu, J. Org. Chem., 2011, 76, 2056-2061.

193 Z.-B. Cheng, X. Lu, J.-M. Bao, Q.-H. Han, Z. Dong, G.-H. Tang, L.-S. Gan, H.-B. Luo and S. Yin, J. Nat. Prod., 2014, 77, 2651-2657.

194 C. L. Cardoso, I. Castro-Gamboa, G. M. Bergamini, A. J. Cavalheiro, D. H. S. Silva, M. N. Lopes, A. R. Araujo, M. Furlan, H. Verli and V. S. Bolzani, J. Nat. Prod., 2011, 74, 487-491.

195 X.-Q. Zhang, F.-F. Xu, L. Wang, M.-Y. Huang, Z. Liu, D.-M. Zhang, G.-C. Wang, Y.-L. Li and W.-C. Ye, Phytochem. Lett., 2012, 5, 292-293.

196 J.-F. Wang, G.-F. Yin, X.-J. Zhou, J. Su, Y. Li, H.-M. Zhong, G. Duan and Y.-X. Cheng, J. Asian Nat. Prod. Res., 2011, 13, 80-83. 
197 S. Begum, B. Saxena, M. Goyal, R. Ranjan, V. B. Joshi, C. V. Rao, S. Krishnamurthy and M. Sahai, Fitoterapia, 2010, 81, 178-184.

198 M. J. Nunez, M. L. Kennedy, I. A. Jimenez and I. L. Bazzocchi, Tetrahedron, 2011, 67, 3030-3033.

199 Z. Liang, J. Zhang, X. Zhang, J. Li, X. Zhang and C. Zhao, J. Chromatogr. Sci., 2015, 54, 175-178.
200 J. X. Huang, J. Zhang, X. R. Zhang, K. Zhang, X. Zhang and X. R. He, Pharm. Biol., 2014, 52, 1237-1243.

201 S. Kusari, M. Lamshöft and M. Spiteller, J. Appl. Microbiol., 2009, 107, 1019-1030.

202 S. Kusari, C. Hertweck and M. Spiteller, Chem. Biol., 2012, 19, $792-798$. 